\title{
قيود حرية الموظف العام فى التعبير عن رأية ( دراسة هقارنة )
}

\author{
shel \\ أ.د / فرحان نزال أحميد المساعيد \\ أستاذ القانون الدستورى والإدارى \\ كـليت القانون - جامعتَ آل البيت ـ الأردن \\ و المحامى / بدر محمدد هلال أبو هوبمل \\ ماجستير فى القانون
}




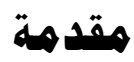

شهدت المملكة الأردنية الهاثمية على مدى السنوات القليلة الماضية جملة من الإصلاحات السياسية، والاقتصادية، والاجتماعية، والتي طالت جميع جوانب المجتمع الأردني كخطوة واثقة لا نكوص عنها نحو الإصلاح الثامل الذي دعا إليه جلالدة الملتك

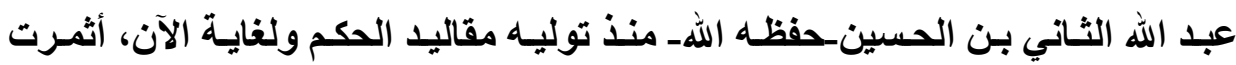

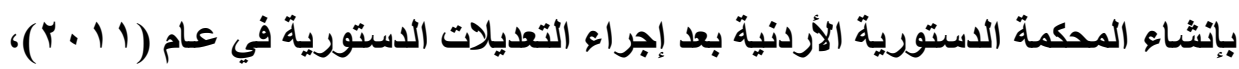

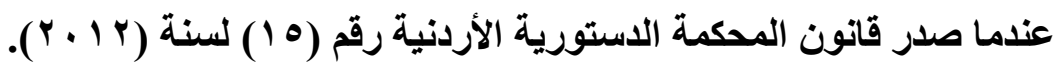

ونظرا لما أحلثته هذه التعديلات الاستورية، وما أثمر عنها بإنثاء هيئة قضائية

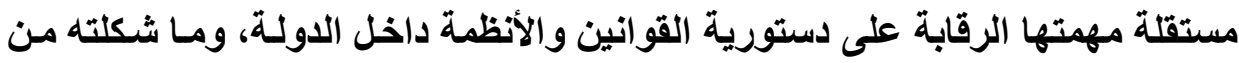

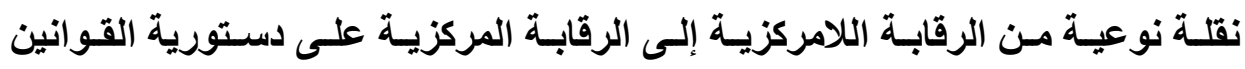

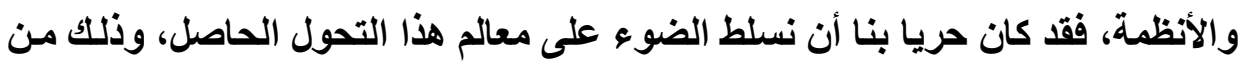
خلال بيان الطرق الجديدة التي جاء بها الاستور الأردني لتفعيل هذه الرقابة. وتبرز أهمية هذه الدراسة في بيان الطرائق التي يمكن من خلالها الطعن بعدم دستورية أي قانون، أو نظام ناقذ داخل الدولة من خلال الطعن المباثر، أو من خلال الطعن المباشر بطريق غير مباثر، أو من خلال الدفع الفرعي، وهو الطريق الذي يمكن

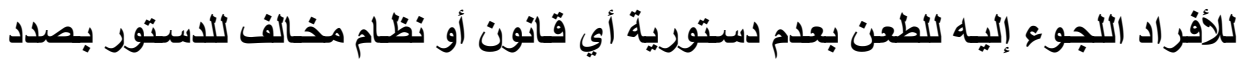

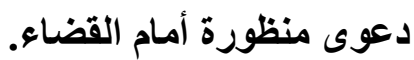
ولمَّا كـان ذلك، وبيانتاً لمـا في الرقابـة الاستورية المركزيـة من معطيات، فقد

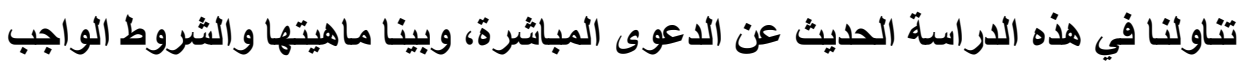


تو افرها فيها، كما بينا كل ما يتعلق بالدفع الفرعي، وبينا شروط هذا الدفع على نحو مفصل لكل شرط من هذه الثروط، كما واشرنا إلى وجود طريق بديل يمكن من خلالها لكلأفر اد ممارسة الدعوى المباثرة بطريقة غير مباشرة. كما تطرقنا للحديث عن الأحكام والقرارات التي تصدر عن المحكمة الاستورية، وبينا إجراءات إصدار هذه الأحكام والقرارات، كما واشرنا إلى الشروطو والضوابط التي تحكمها، كمـا بينـا كل مـا يتعلق بحجيـة هذه الأحكام والقرارات، وكل مـا يتعلق بنفاذها. وسوف نقوم بمناقشة كل مـا تقدم بيانـه بالمقارنة مع مـا هو عليه الحـال في القضاء الدستوري لدى جمهورية مصر العربية، بما يقابل هذا الجزئيات المشار إليها

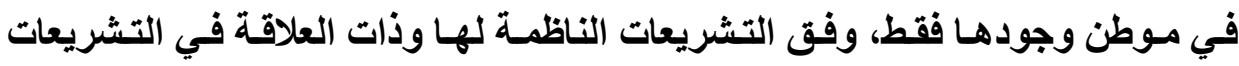

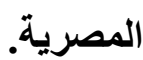
وتمـر الدعوى الاستورية بعدة مراحل، أحسال فيها الاستـور،(') إلـى قـانون

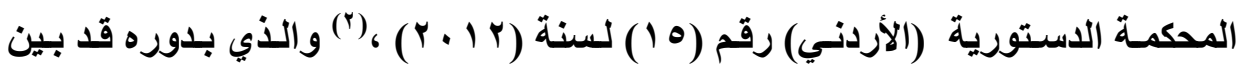
ونظم كافة الإجراءات التي تبين الآلية التي تتصل فيها الدعوى الاستورية بالمحكمة

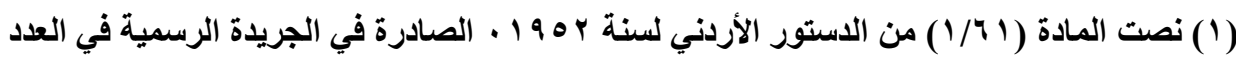

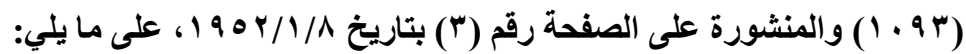

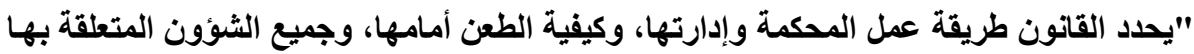

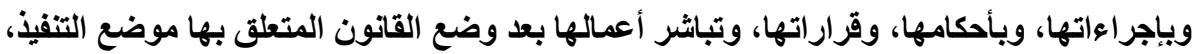
ويبين القانون حقوق أعضائها وحصانتهر".

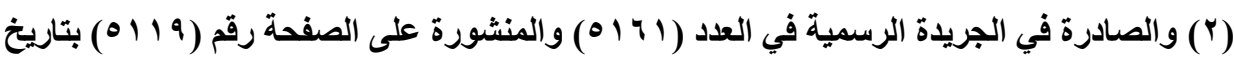


اللستورية، من خلال وضع التعليمـات اللازمة لذلك،، (') وبين الإجراءات العملية التي تتبع في اللدعوى الدستورية المباثرة والدفع الفرعي، وصدولا إلى الدكم الصادر

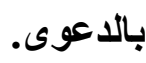

كما أن المشرع الاستوري المصري في دستور سنة (ع ا ب ب) قد أحال أيضا إلى

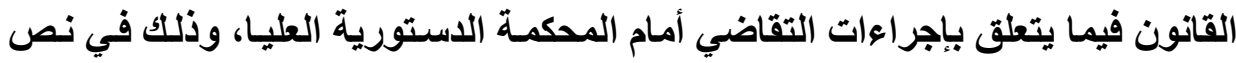

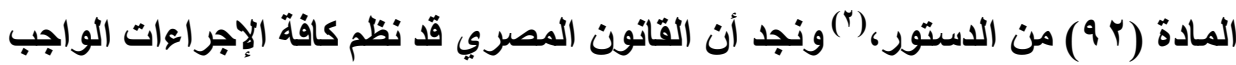

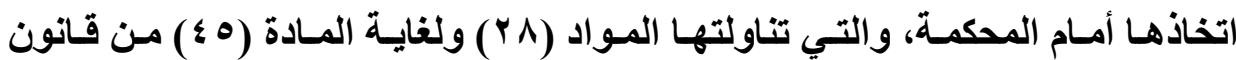

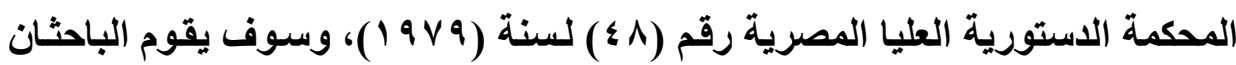

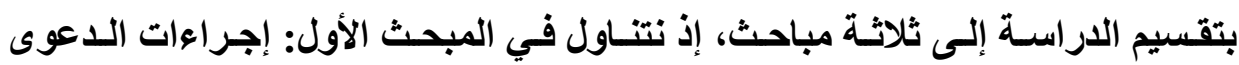

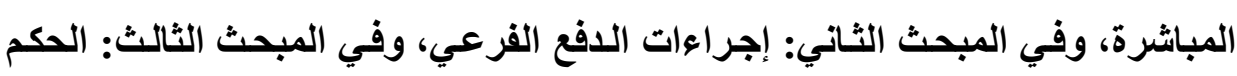
الصادر في الدعوى الاستورية وحجيته و آثار هذه الأحكام والقرارات.

(1) حيث تم وضع تعليمات إجراءات الفصل في الطعون وطلبـات التفسير الصادرة عن الهيئة العامـة

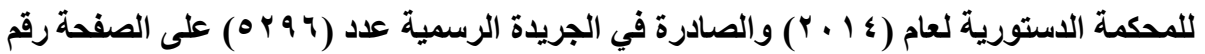

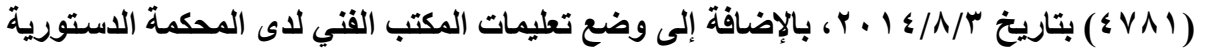

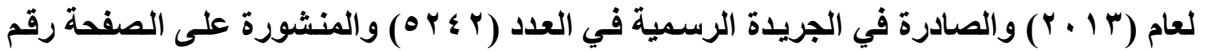

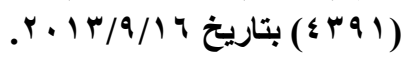

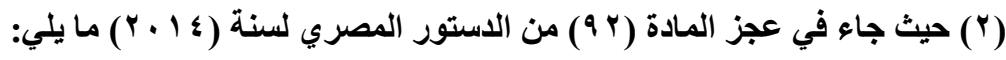
".. ويعين القانون الاختصاصات الأخرى للمحكمة، وينظم الإجراءات التي تتبع أمامها". 


\section{المبحث الأول}

\section{الدعوى المباشرة}

تعتبر الرقابة الاستورية على القوانين والأنظمة من خلال الطريق المباثر من

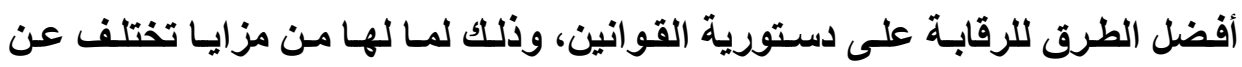
تلكـ التـي في الطرق الأخرى مـن الرقابـة، كمـا تعتبر الخصومة الاستـورية عينيـة

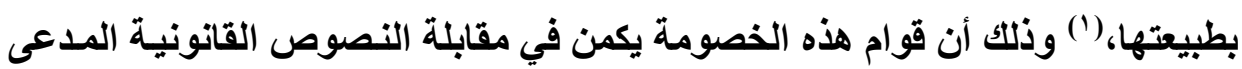
بمخالفتها للاستور، () وتوضسيحا لـذلك نقسم الاراسـة إلى مطلبين: المطلب الأول

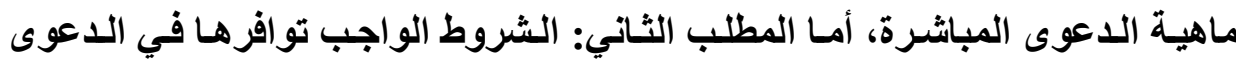

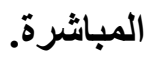

المطاسب الأول: هاهيسة السدعوى المباشــرة: تعتبر اللدعوى المباثـرة مـن الدعاوى الموضوعية التي تخاصم القانون أو النظام المخالف للاستور، ويتطلب لإقامـة

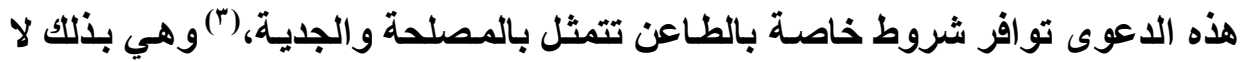
تعتبر دعوى حسبة.

(1) وتوصف الدعوى الدستورية بانها دعوى عينية لأها تخاصم القّانون أو النظام المخالف للاستور وتهاف لإبطاله.

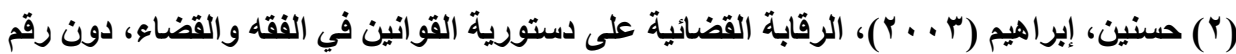

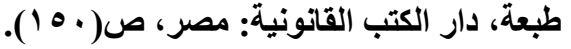

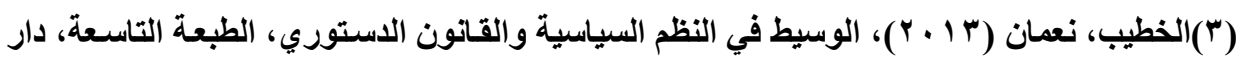

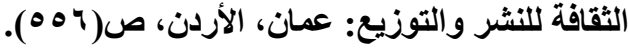

مجلتّ البحوث القانونيت والإقتصاديت بره 
ويقوم هذا النوع على أساس أن رقابة دستورية القوانين يجب أن تكون نابعة من السلطة القضائية، إذ أنها وحدها بمـا لها من حياد واستقلالية تسنطيع أن تقول كلمتها في هذا الثأن لإبطال التشريعات المخالفة للاستور، أو مناقثة مدى دستوريتها، إذ أن هذه المناقثة هي في ذاتها خصومة تأخذ صورة الدعوى، وتكون نتيجة البحث في هذه الدعوى إحدى أمرين: إمسا الحكم ببطلان التشريع، أو عدم قبول الدعوى لأي

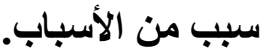

وقد درج بعض الفقهاء على تسمية الدعوى المباشرة بدعوى الإلغاء،(() والتي

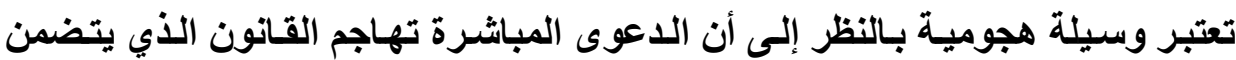
مخالفة الاستور، كما تتطلب هذه الوسيلة أن يكون الاختصاص في هذه الدعوى معقودا لجهة قضائية واحدة دون غيرها؛ منعا لتضارب الأحكام القضائية. (†) ويثكل هذا الأسلوب من الرقابة الاستورية مبادرة من صاحب الشأن يقيمها

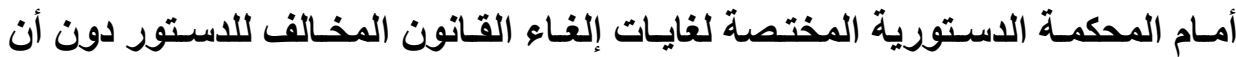
ينتظر حتى يطبق عليه ذلك القانون، (") والذي يشكل أيضا إجراءا وقائيا لمصلحة

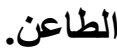

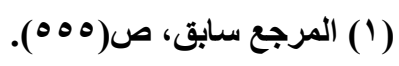

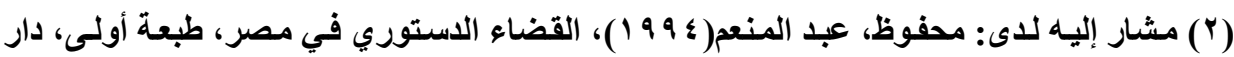

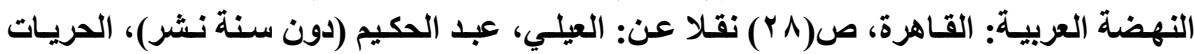

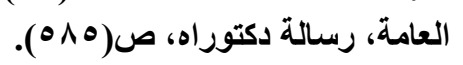

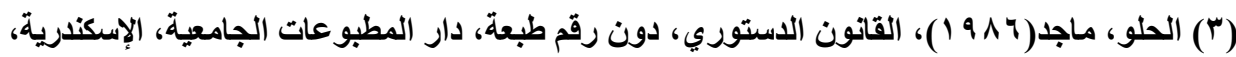
ص(r) (r) (r) (r) 
ويمكن أن نعرف الطعن المباشر على أنه الطريق الذي تلتجئ من خلاله الجهات التي حددها القانون للطعن في أي تثريع تعتقد بأنه غير دستوري أو قد اعتراه شبهة دستورية، لغايات استصدار حكم يقضي بإلغائه.

وبناءا على ذلك فأنه يمتتع على الأفراد اللجوء إلى المحكمة الاستثرية بشكل مباشر للطعن في أي قانون أو نظام يعتقدون انه يخالف الاستور ما لم يجد هذا التشريع طريقه للتطبيق على الأفراد بعد، وما لم يوجد سند قانوني يبيح للأفراد ذلك، وبالتالي لا يبقى لهم إلا طريق الدفع الفرعي عند تطبيق النص عليهم فقط. كما أن الرقابة الدستورية عن طريقة الدعوى المباشرة يقتضي أن يكون هناك جهاز قضائي مختص بهذا النوع مـن الدعاوى الاستورية، بـالنظر إلى أهميتها مـن ناحية، وحتى لا يقع تعارض بين أحكامها من ناحية أخرى. (') ونلاحظ أن المشرع الاستوري الأردني قد قصر حق إقامـة الدعوى الدستورية بالاعتماد على الأسلوب المباشر بثُلاث جهات حصراً، وهم مجلس الوزراء، ومجلس

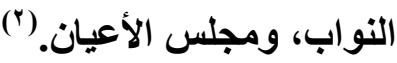

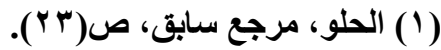

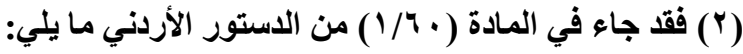

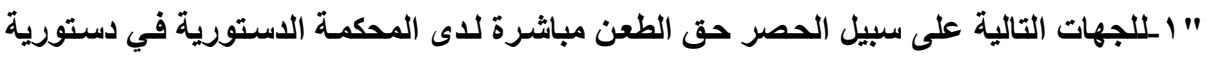
القو انين والأنظمة الناقذة:

$$
\text { بـ أـ مجلس الأعيان. }
$$

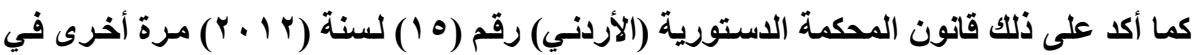

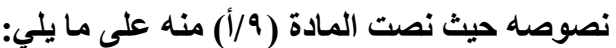


في حين أن المشرع الدستوري المصري، وكذلك المشرع القانوني المصري لم يتطرقا للحديث عن هذا الطريق من طرق الرقابة على الإطلاق، و إنما اقتصر حديثهر

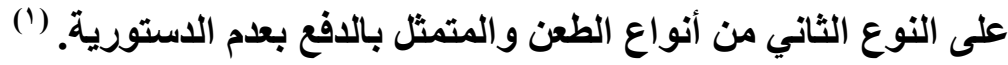
وسوف نقتصر حديثنا في هذه النقطة على التشريع الأردني، بالنظر إلى أن المشرع المصري لم يتناول الإثارة إلى هذا الطريق في تشريعاته الناظمة لإجراءات

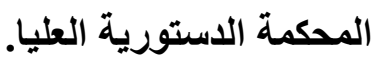
ونلاحظ أن المشرع الأردنسي لم يكن موفقاً عندما قصر حق الطعن على هذه الجهات الثلاث حصرا، بخلاف بعض التشريعات التي سبقتنا في هذا الميدان وهو مـا دعانا لتوجيه سهام النقد للمشرع الاستوري الأردني حيال هذا الأمر في ثلاثة محاور

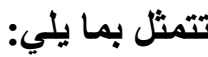

\section{1- حرهان السلطة القضائية هن حق الطعن.}

إذ نجد أن المشرع الاستوري الأردني عذدما نص على اقتصار حق الطعن على الدى

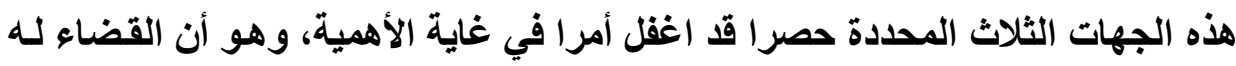
دور بارز وفاعل في الكشف عن النصوص المخالفة للاستور بمـا يفوق مـا للسلطة

"أـ للجهات التالية على سبيل الحصر حق الطعن مباشرة للاى المحكسة في دستورية القوانين

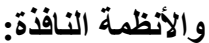

$$
\begin{aligned}
& \text { ا اـمجلس الأعيان. } \\
& \text { rا بمجلس النواب. } \\
& \text { rامجلس الوزراء". }
\end{aligned}
$$

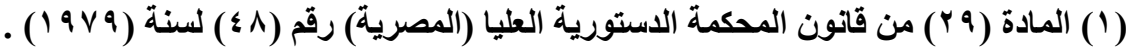


التنفيذية، والسلطة التثريعية، وبالنظر إلى أن السلطة القضائية هي الجهة التي تقوم بتطبيق النص القانوني، وبالتالي فهي أكثر قدرة على تحديد ما يعتري النص من عيب، وخلل، وقصور، قد يصل به إلى مصاف عدم اللستورية في بعض الأحيان.

\section{r- حرمان الأفراد، والأشخاص الاعتبارية هن حق الطعن}

إذ يرى الباحثان أن المشرع الدستوري الأردني قد اخطأ عندما قصر حق الطعن على هذه الجهات الثثلاث فقط، دون الإثـارة إلى حق الأفراد، والأشخاص الاعتبارين بهذا الأمر إلا من خلال دفع فرعي، نتيجة اتخاذهم لصفة الخصومة في قضية منظورة أمام القضاء، وهو أمر منتقد من المشرع الدستوري الأردني، فليس من المنطق بمكان أن نتنظر القانون، أو النظام المخالف للاستور أن يطبق على الافراد حتى يتمكنوا من الطعن فيه، إذ كان من الأجدر بالمشرع الدستوري الأردني أن أضاف هذا الحقى لهاتين الفئتين، مع وضع ضمانات خاصة في الدعوى لعدم اللجوء إليها على نحو خاطئ، وذلك بوضع شروط واضحة، ومحددة، تثبت جدية ومنطقية الطعن من قبل هذه الفئات قبل أن يقدم الطعن إلى المحكمة الاستورية. ويذكر أن جانب مـن الفقهـ الاستوري الأردنسي قد وصف الرقابـة الدستورية

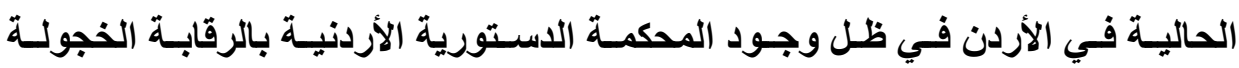
و المتو اضعة والتي لا ترقى إلى مستوى الرقابة القضائية المثالية وذلك لعدة أسباب

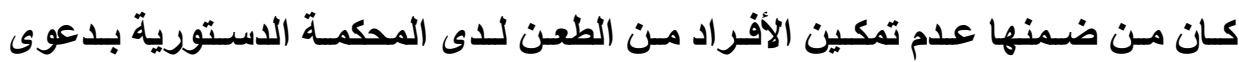

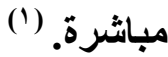

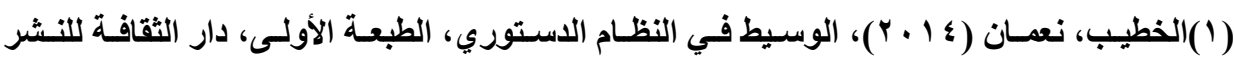

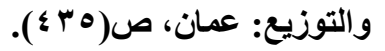

مجلتّ البحوث القانونيت والإقتصاديت و به 
ويشار إلى أن بعض التثريعات المقارنة قد منحت الأفراد حق الطعن المباثشر

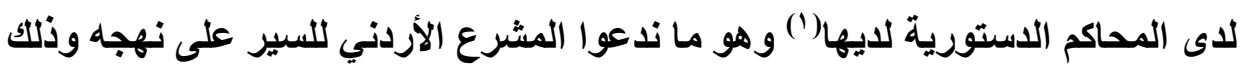

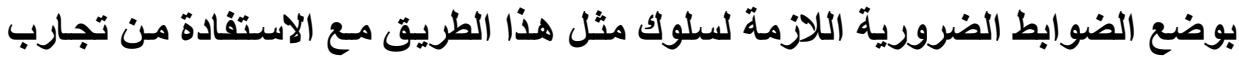

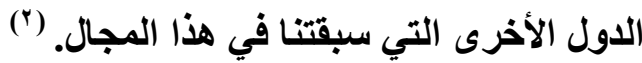

ونحن نـرى وعلى الرغم مـن هذا الحرمسان الذي فرضسه المشرع الاستوري

الأردني على الأفراد والهيئات المعنوية، أن الأفراد لم يحرموا بشكل كلي من حقهم في الطعن بدعوى مباشرة، إذ أن هناك طريق بديل يمكن لهم أن يطعنوا من خلالهه بـعوى مباشرة بطريقة غير مباشرة.

ونؤسسس مـا ذهبنـا إليهه حول هذا الطريـق البديل بالاستنتاد لبعض نصوص الدستور الاردني، فعند استعراض نص المادة (1 ) من الدستور الأردني نراها تؤكد على

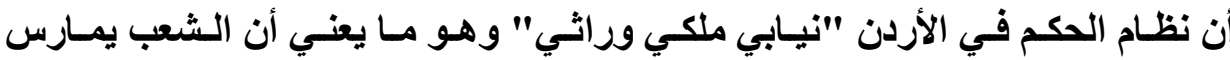
السلطة من خلال نواب يتم انتخابهم لفترة محدودة، يقومون خلال هذه الفترة بإيصال صوت الثعب إلى الحكومة من خلال قنوات الاتصال المفتوحة فيما بينها. كما أشارت المادة (VV) من الاستور الأردني على أن مجلس النواب يتكون من

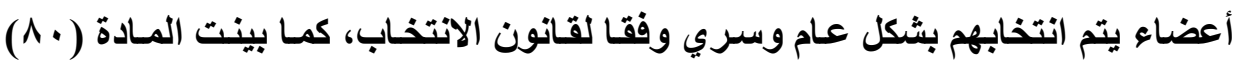

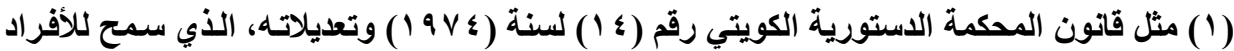

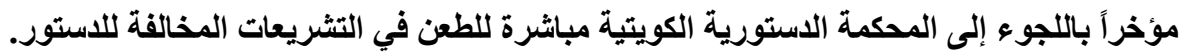

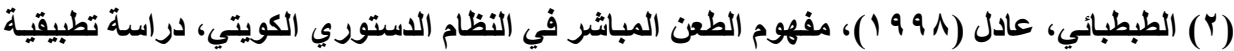

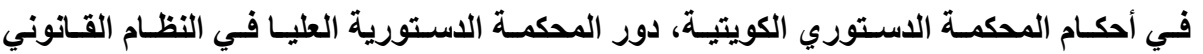

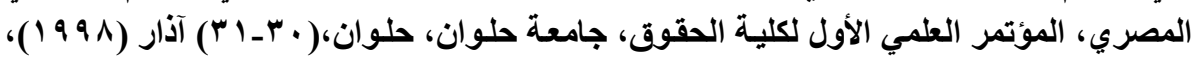

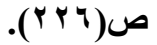

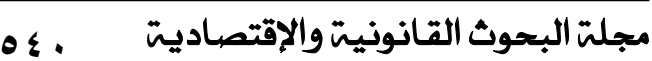


مـن الدسـتور الأردنسي القسم الــي يتعين على النـواب، والأعيـان، الإدلاء بـهـ قبل ممارستهم لمهامهم أمسام مجلسهم، والتي جاء نصها على النحو التالي: (اقسم بـالله العظيم أن أكون مخلصاً للملكت والوطن، وان أحسافظ على الدستور، وان اخدم الأمـة، وأقوم بالواجبات الموكولة إلي حق القيام). و النائب يمثل الأمة كافة، أي جميع أفراد الشعب كوحدة واحدة، وذلك في ظل مبدأ سيادة الأمة، (') والذي يعتنقه الاستور الأردني بدليل المادة (ع ب/ 1) منه. وبالتالي فأن هذه النصوص الاستورية جميعا تدور حول محور واحد وهو أن الفرد هو أساس هذا الوطن، وما هنالكك من سلطات داخل الدولة هي في حقيقة الأمر موجودة لخدمته، ولتسهيل أمور حياته، بمـا في ذلك المجلس النيابي (مجلس الأمسة)

$$
\text { بثقيه النواب، والأعيان. }
$$

وتجسيدا للذلك فقد وردت العديد مسن النصوص في النظام اللـاخلي لمجلس

النواب،(") ومجلس الأعيان،(") والتي تثير إلى وجود قنوات اتصال يمكن من خلالها إيصال صوت الثعب للمجالس النيابية، والتي بدورها تتفذ مطالبهر انطلاقا من كون هذه المجالس لا تعدو أن تكون لسان الثعب الذي ينطق بمطالبهم وهمومهم، فضلا عن لـن

(1) ويقصد بهذا المبلأ أن الأمة هي مصدر السلطات داخل الدولة.

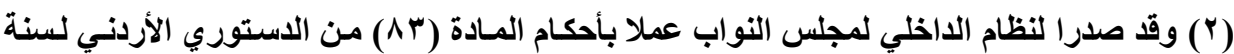

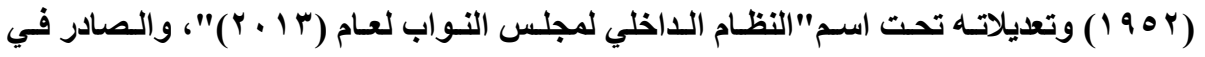

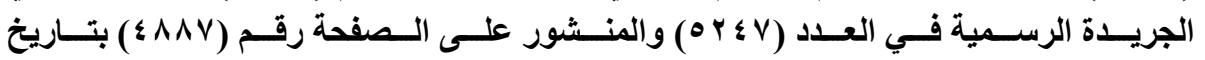

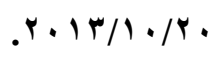

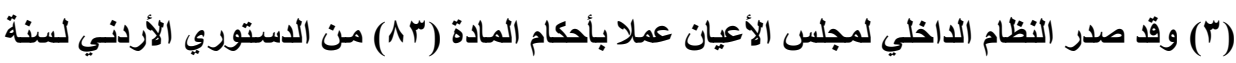

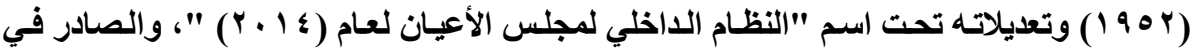

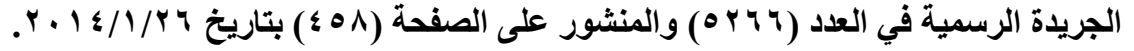


حقهم الدستوري في تقديم العرائض في كل ما ينوبهم من أمورهم الثخصية أو كل مـا

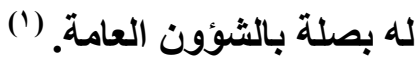

فبالنسبة للقتوات التي أثـار إليها النظام الداخلي لمجلس النواب رقم لسنة

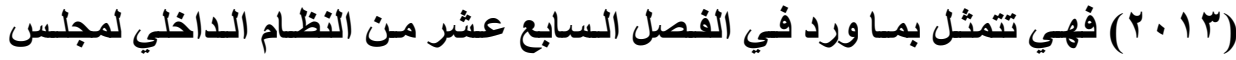
النواب(")، أما بالنسبة للقتوات التي أثـار إليها النظام الداخلي لمجلس الأعيان لسنة

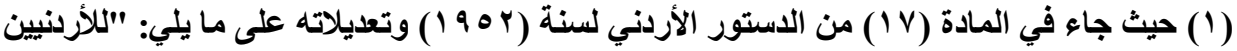

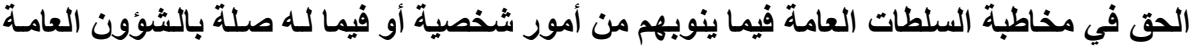
بالكيفية والثروط التي عينها القانون".

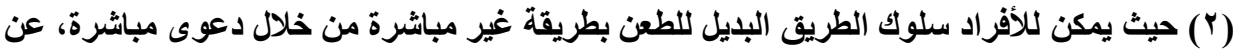

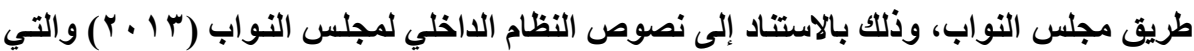

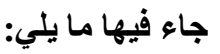

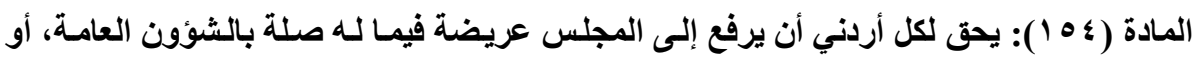
شكوى فيما ينوبه من أمور شخصية. المادة (100): أـ يجب أن يوقع على العريضة، أو الشكوى مقدمها ذاكرا فيها اسمه، ومهنته،

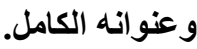

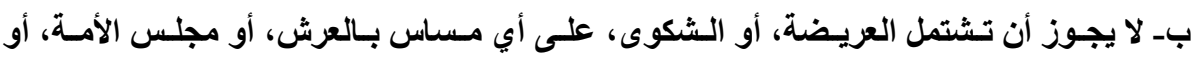

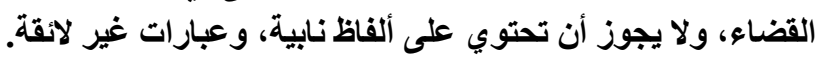

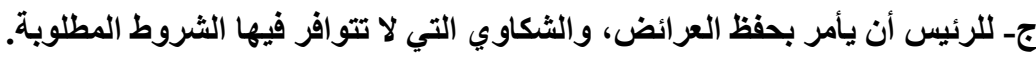

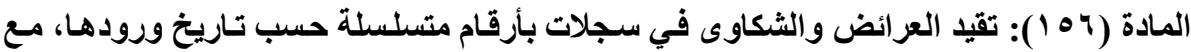

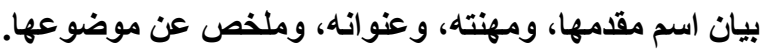

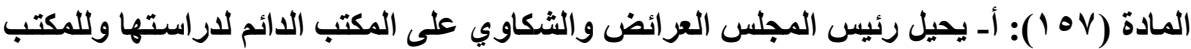

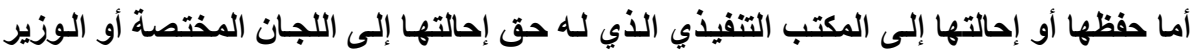

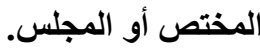
بــ إذا أحيت العريضة أو الثكاوي إلى اللجنة المختصة تقوم اللجنة بدراستها وتقرر أمـا حفظها،

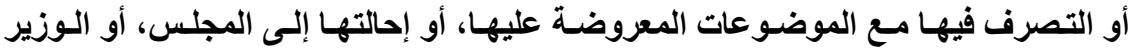

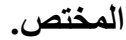
$=$ 


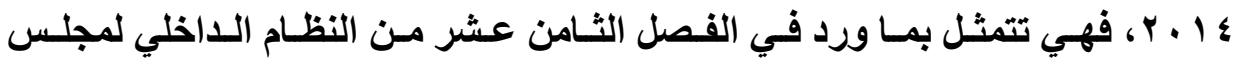

ج- يجيب الوزير على العريضة، أو الثكوى المحالة إليه خلال أربعة عشر يوما، ويرسل الرئيس إلى مقدمها بما تم فيها.

المادة (101): لكل عضو حق الاطلاع على أية عريضة، أو شكوى، متى طلب ذلك من رئيس

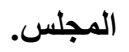

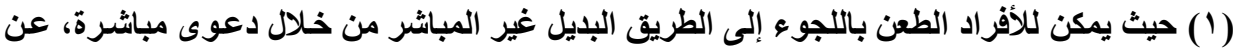

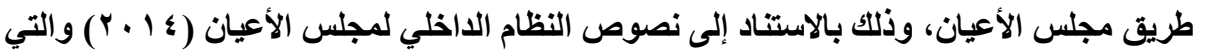
جاء فيها ما يلي: - و الأي الفصل الثالث عثر - العرايض والثكاوى الثادي

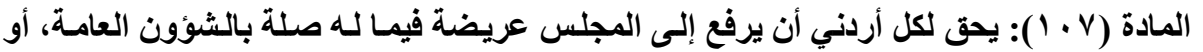
شكوى فيما ينوبه من أمور شخصية. المادة (1 + (): أ- يجب أن يوقع العريضة أو الثكوى مقدمها ذاكرا فيها اسمه، ومهنته، وعنوانه

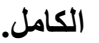

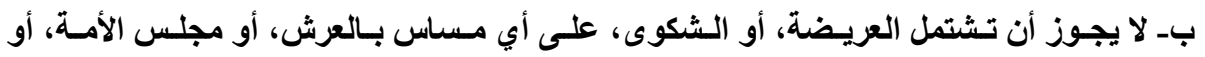

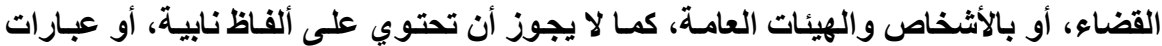

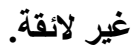
ج- للرئيس أن يأمر بحفظ العرانض، والثكاوى التي لا تتو افر فيها الثروط المطلوية.

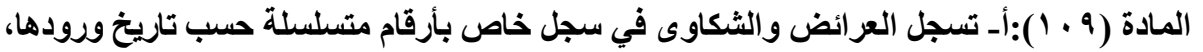

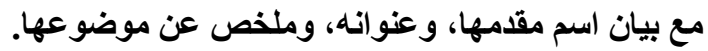

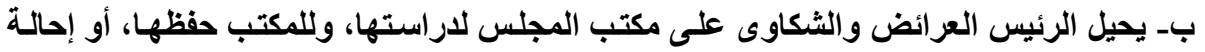
الثكاوى إلى اللجنة الإدارية، أو إحالة العرائض إلى اللجان المبلى المختصة.

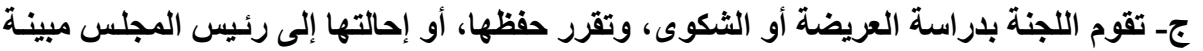
رأيها فيها، ويحيل الرئيس ما يرى إحالته منها إلى الوزير المختص لإبداء رأيه فيها خلال شهر

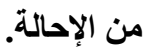

دـ يرسل الرئيس إلى مقدم العريضة أو الثكوى بيانا فيما تم في المقبول منها. هـ لكل عين حق الاطلاع على أي عريضة، أو شكوى متى طلب ذلك من رئيس المبل فئس. 
ويبرز دور هذه القتوات في الضغط على المجالس النيابية نوابا، وأعيانا، وذلك

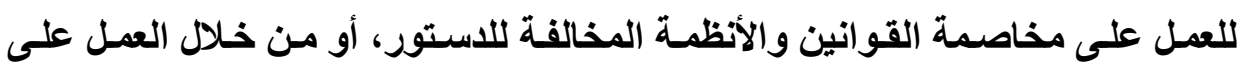
تعليلها، إذ أن هذا الاعتداء على الاستور هو في حقيقة الأمر اعتداء على العقد الذي كانت قد أبرمته الأمة مع الحاكم بالنظر لطبيعته العقدية. أضف إلى ذلك أن عدم الاستجابة من قبل أعضاء المجالس النيابية لمطالب الثعب قد يؤدي إلى وقوع نتائج في غاية الخطورة تنعكس على هذه المجالس ممـا يؤدي إلى مقتهم من قبل الثعب، وحدوث مظاهرات، واعتصام، لغايات التنديد بتجاهل هذه المجالس لمطالب الثعب، والتي كنا قد رأيناها مرارا في السنوات القليلة الماضية،

$$
\text { وهو آخر ما يتمنى المجلس النيابي وقوعله ولته }
$$

ومن ناحية أخرى فأن وسائل الإعلام تلعب دورا واسعا في هذه المجال بالنظر إلى تطور الوسائل التكنولوجية، وتناقل الأخبار بين مختلف الجهات الرسمية والثُعبية، وظهور شبكات التواصل الاجتماعية، والتي شكلت في الفترة الأخيرة منبرا لرجـال

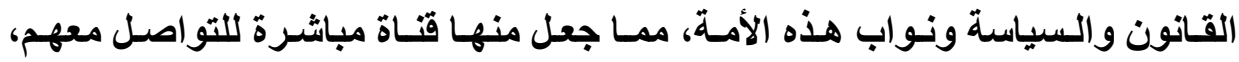
والعكس صحيح، وذلك من خلال متابعة أخبار الثبع عبر هذه الوسائل مما يشكل في نهاية الأمر وسيلة ضغط شعبية تؤدي إلى تحرك هذه الجهات لتتفيذ مطالب الشعب،

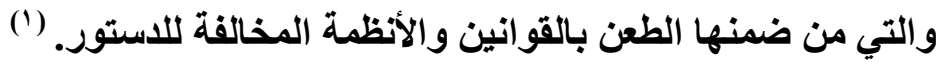

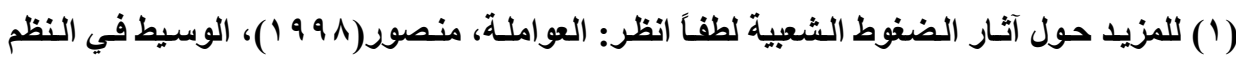

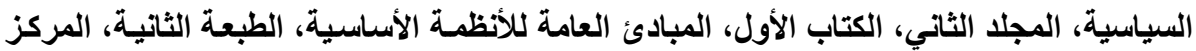

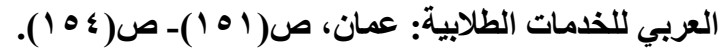


كما لا يمكتنا الاستهانة بوسائل الاتصال الديثة ودورهـا في هذا المجال، إذ أن أثرها قد تعدى الحدود كما كنا قد شاهدنا في الأعوام الماضية في دول الجوار. r- هنح الجهات المددة حصراً حق نقض ها تم هن قبلها. وهو أمر غير منطقي إذ عندما يمنح المشرع لسلطة معينة سلطة التشريع، ويمنحها حق الطعن في ذلك التشريع، فكيف للسلطة أن تنقض مـا تم من قبلها! ونحن

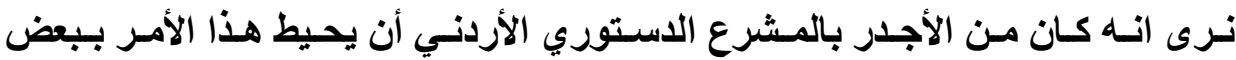

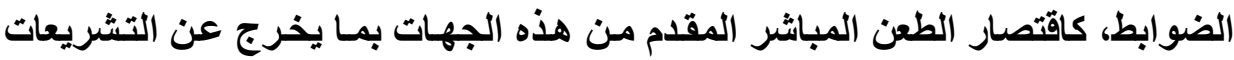
التي قامت هذه الجهة بسنها. وسندنا فيمـا ذهبنـا إليهه هو أمر بلديهي يمكن توضيحه بمثال عملي بسيط، فنفرض جدلا أن مجلس النواب يرغب بالطعن بالنظام الداخلي لمجلس النواب والصادر بموجب المسادة (rA) مـن الاسـتور، فهـل يتصور أن يقوم مجلس النـواب بالتوجـه للمحكمة الدستورية للطعن في هذا النظام؟ أم يمكن له أن يسلك الطريق الأقصر وهو لهو

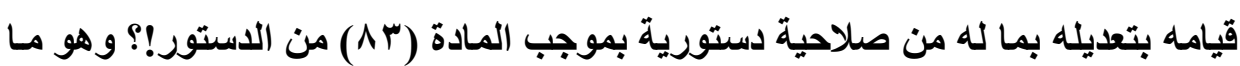
سوف يفعله في الحقيقة، وبالتالي فأن حرمان مجلس الأمة من الطعن بنظامها الداخلي واقتصاره على الطرق الاستورية البديلة هو أولى من ابقاء النص على حالته الراهنة،

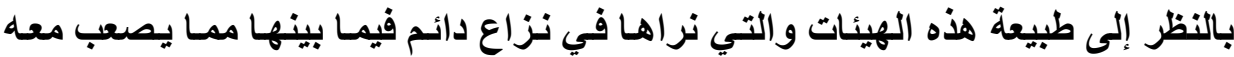

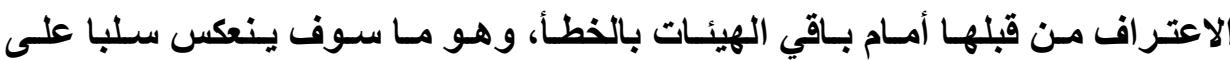

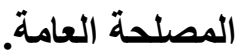
وبنـاءا على ذلكت فـلا نتفق مـع الجاتب الفقهي الذي يـرى أن اقتصار الطعن

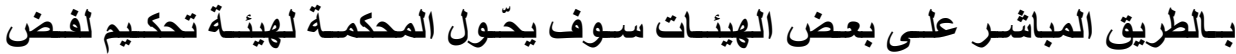


المنازعـات اللـائرة بـين السلطات العامـة، (') إذ يـرى الباحثـان أن الغايـة مـن أنشـاء الحكمة الدستورية تحمل في طياتها اعتبارات عدة والتي كان من ضمنها تفعيل الرقابة بين السلطات العامة في الدولة، بالإضافة إلى هدفها الأساسي وهو حماية الاستور من أي انتهاك، وقد نجـح المشرع الاستوري الأردنسي مـن تحقيق ذلكت في نص المسادة

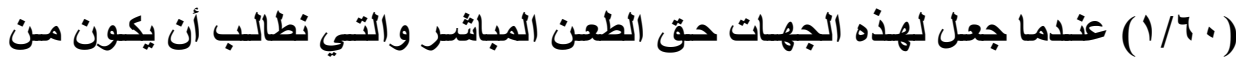

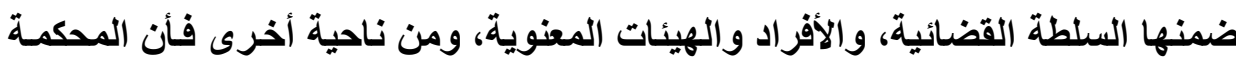
الدستوري حتى ولو أصبحت كهيئة تدكيم كما وصفها هذا الجانب الفقهي فهي لن تقف مكتوفة الأيدي عندما يعرض عليها نص مخالف للاستور، اذ تقوم بإعمال كافة أسلحتها لاستئصاله وإبقائه بعيداً عن الأفراد، حماية لهم ولحقوقهم التي كفلها الدستور. كما أن الطعن بعدم الاستورية يمثل وسيلة تقوم من خلالها السلطة التشريعية بالرقابة على أعمال السلطة التنفيذية وهي بصدد إصدار الأنظمة المستقلة التي تنفرد في إصدارها، وهو ما يدعو كل جهة إلى الالتزام الكامل بالاستور عند قيامها بوظيفتها التشريعية بشكل أصيل، أو استثنائي في المستقبل، حتى لا تقع التشريعات الصادرة عنها ضحية للطعن بعدم الاستورية من قبل غيرها من الجهات.

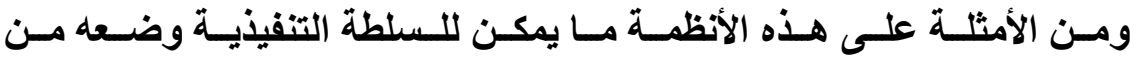

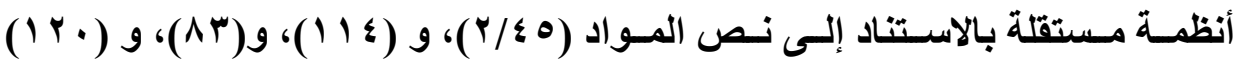
من الاستور الأردني، وبالتالي تبقى تحت رقابة السلطة التشريعية التي تراقب هذه

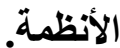

(1) بدوي، ثروت (ع ج 9 (1)، النظام الاستوري العربي، دون رقم طبعة، دون ناثر، دون مكان نشر،

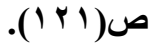

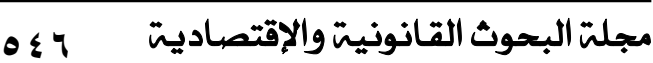


المطاب الثاني: الشروط الواجب توافرها في الطعن المباشر: و تتمثل هذه

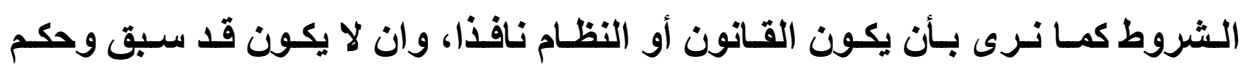
بطظلانه، وان لا يكون النص متعلقا تعلق وجودي مع نص آخر قضي ببطلانه، كما يجب

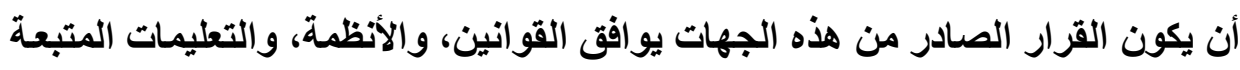
لاى هذه الجهات لغايات إصدار قرار من هذا النوع. ونستعرض هنا الآلية التي تصدر من خلالها القرارات عن هذه الجهات التي حددها الاستور على سبيل الحصر، من خلال الفروع التالية:

الفرع الأول: القرار الصادر عن هجلس الأعيسان: لقد أثشار النظام الداخلي

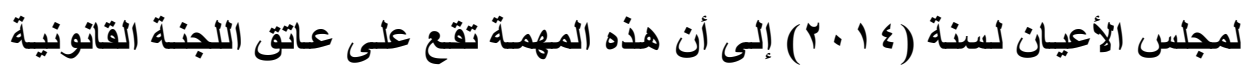

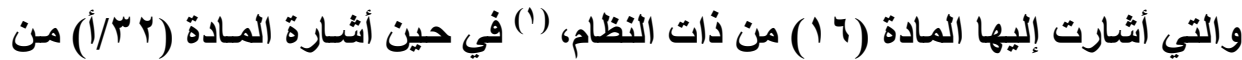

(1) أناط النظام الداخلي لمجلس الأعيان باللجنة القانونية مجموعة من المهام القانونية والقضائية

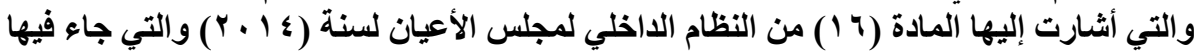
ما واليخ: "اتناط باللجنة القانونية المهام التالية:

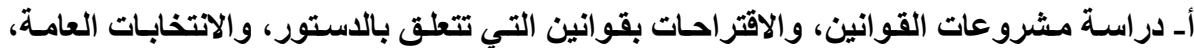

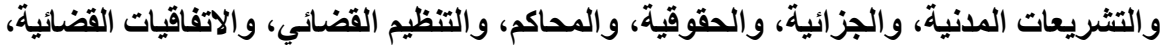

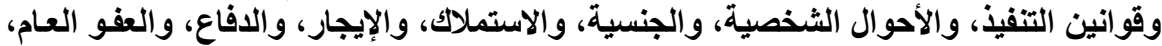
والمخدرات، والمؤثرات العقلية، والنقابات، والأوقاف، وما في حكم تلك التثريعات، وأي قوانين ل التخل في اختصاص لجنة أخرى.

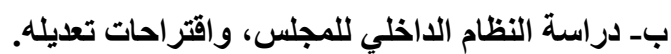
جـ دراسة القضايا المتعلقة بعضوية الأعيان، وحصانتهر. دـ تقليم المساعدة القانونية للجان المجلس الأخرى بناء على على طلب رؤسائها. هـ دراسة تقارير هيئة مكافحة الفسادي و ـ دراسة السياسات والقرارات الحكومية المتعلقة باختصاص عمل اللجنة". 
النظام إلى الثروط الواجب توافرها في كل لجنة من لجان مجلس الأعيان، (') كما بينت

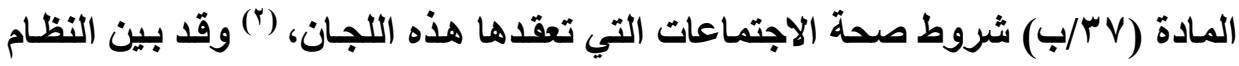
الثروط الواجب توافرها في القرارات التي تصدرها اللجنة (") وهي أن تصدر بأكثريـة الحاضرين المشتركين بالتصويت فيمسا خـلا صسوت الـرئيس، وعند تساوي الأصسوات

$$
\text { يكون صوث الرئيس المرجح. }
$$

الفرع الثاني: القرار الصادر عن هبلس النـواب: فقد أثسار النظام الداخلي

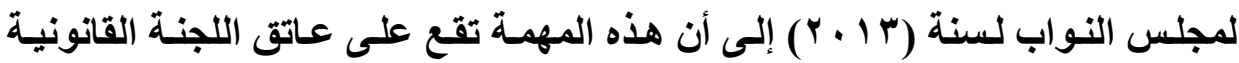

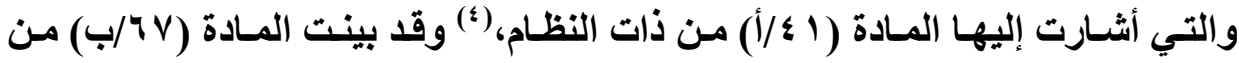

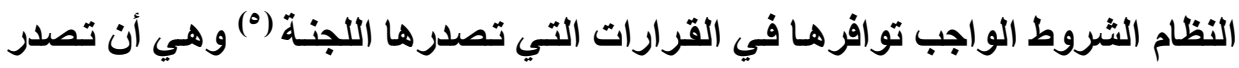

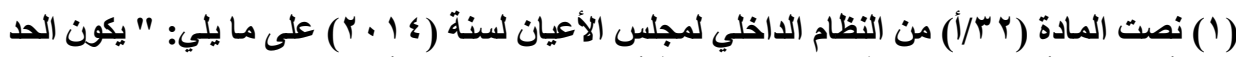

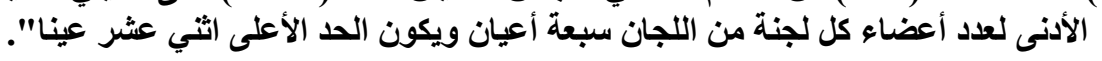

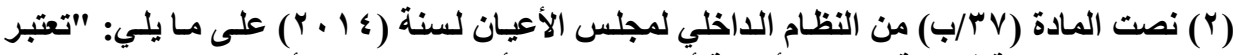

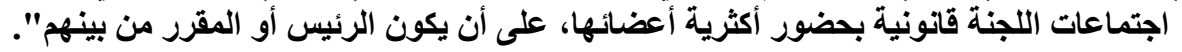

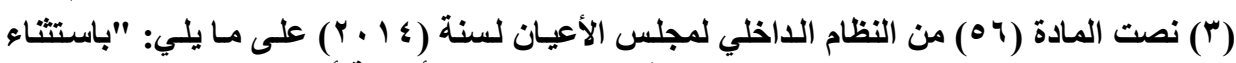

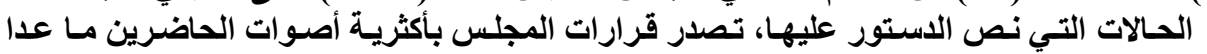

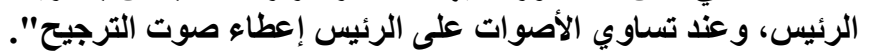

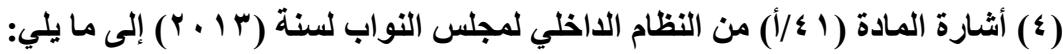
" ت تناط باللجنة القانونية المهام التالية:

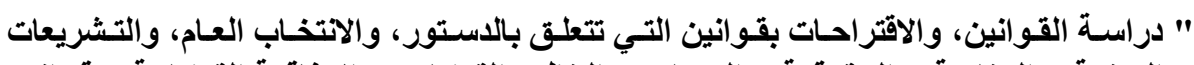

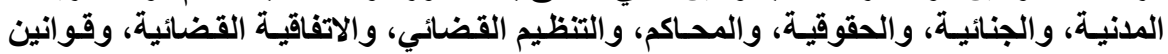

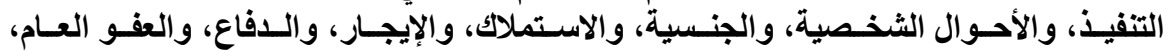

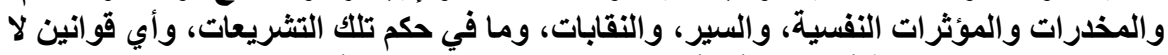

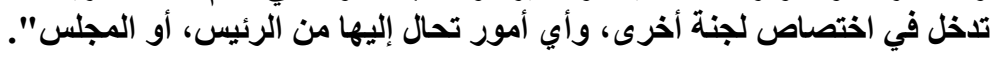

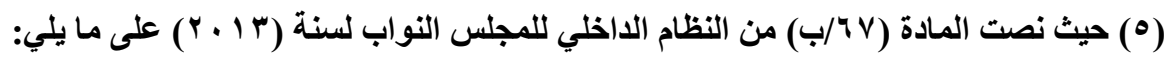

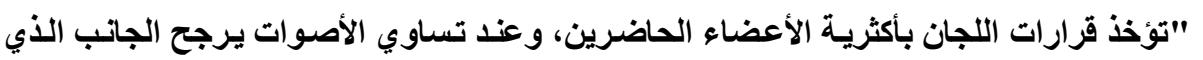

$$
\text { صوت معه رئيس الجلسة ". }
$$


بأكثريـة الحاضـرين المشتركين بالتصويت فيمـا خـلا صسوت الـرئيس، وعند تسـاوي

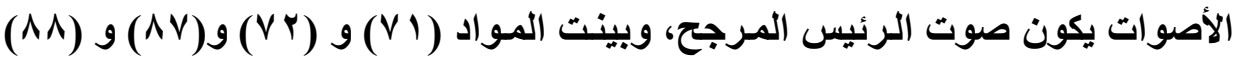

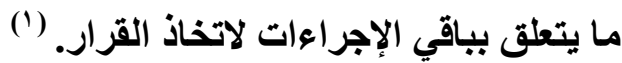

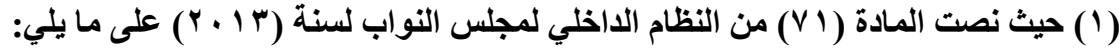

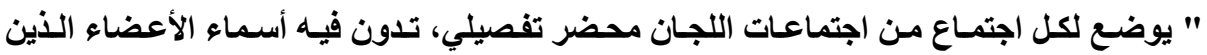

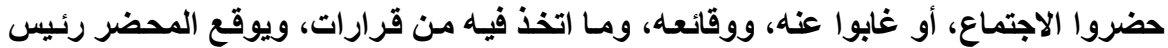

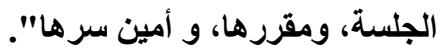

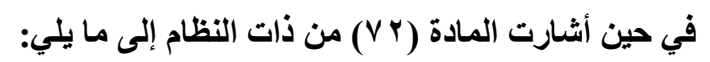

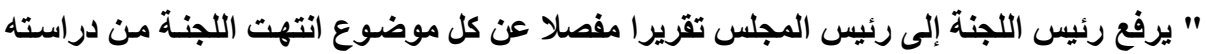

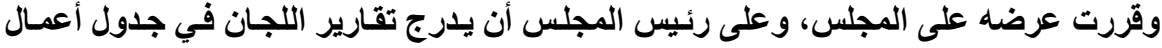
المجلس وفق ترتيب وصولها مع إعطاء الأولوية للمثاريع المستعجلة". كما نصت المادة (Av) من النظام أعلاه إلى الآلية التي يتم فيها التصويت داخل المجلس، والتي جاء

" تصدر قرارات المجلس بأكثريـة الأعضاء الحاضرين مـا عدا الرئيس إلا إذا نص الاستور على الدي خلاف ذلك، وعند تساوي الأصوات يرجح الجاتب الأي صوت معاء الأنه الرئيس". كما وقد بينت المادة (^^) من النظام الطريقة التي يتم فيها المناداة لغايات التصويت حيث جاء فيها ما يلي: "أـ تعطى الأصوات بالمناداة على الأعضاء بأسمائهم، ويصوت عال في الحالتين التاليتين: 1 إذا كان التصويت متعلقا بالدستور يكون الجواب بإحدى الكلمات التالية:

$$
\text { موافق، مخالف، ممتنع. }
$$

r ـ إذا كان التصويت متعلقا بالثقة بالوزارة، أو بالوزراء يكون الجواب بإحدى الكلمات التالية:-

$$
\text { ثقة، حجب، امتناع. }
$$

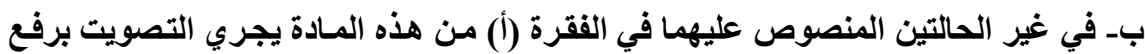

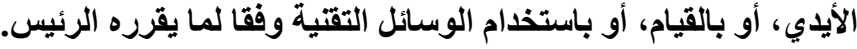

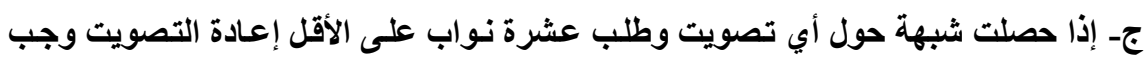

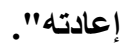


الفرع الثالث: القرار الصادر عن مجلس الوزراء: امسا بالنسبة لقرار مجلس الوزراء فقد أثنار المشرع الدستوري الأردني في بعض نصوصه إلى صلاحيات مجلس

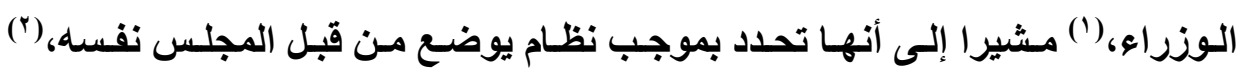

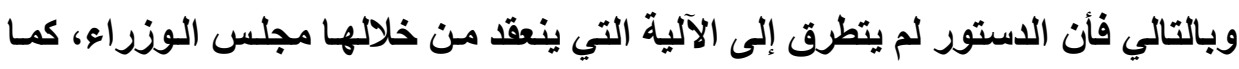

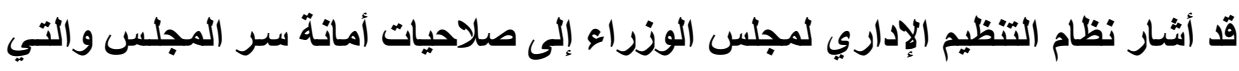

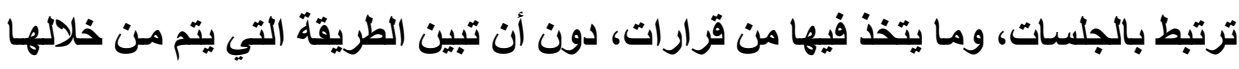

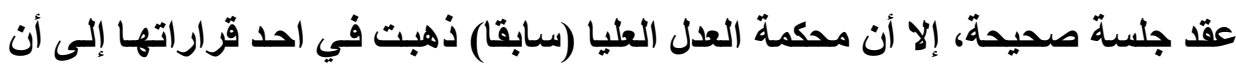

(1) فقدا أثنار اللاستور الأردني في المادة ه ؛ إلى ما يلي:

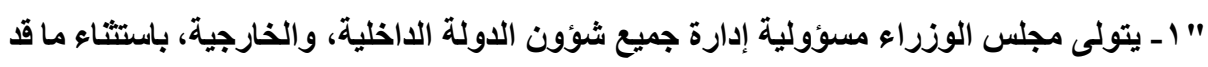
عهل، أو يعهل به من تلك الثؤون بموجب هذا الاستور، أو أي قانون، إلى أي شخص، أولية أو هيئة

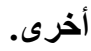
r بتعين صلاحيات رئيس الوزراء، والوزراء، ومجلس الوزراء، بانظمة يضعها مجلس الوزراء،

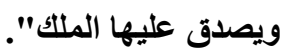
كما أشارة المادة (^^) من الدستور الأردني إلى ما يلي:

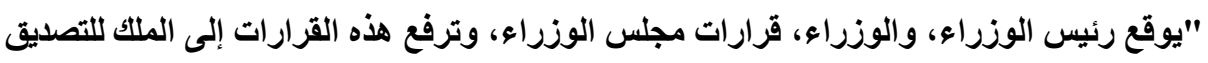

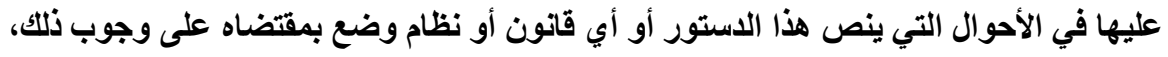

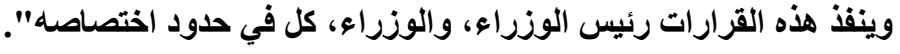

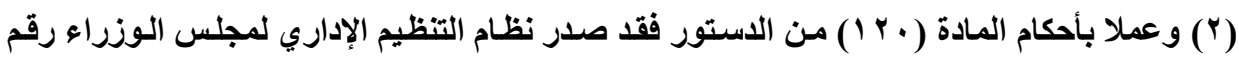

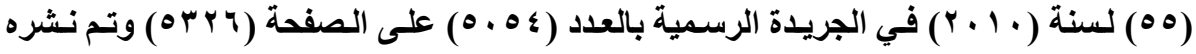

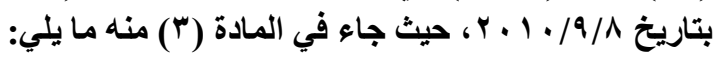

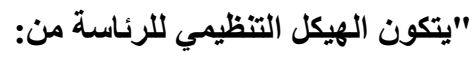
أ-الأمانة العامة، وتتكون من الإدارات التالية:

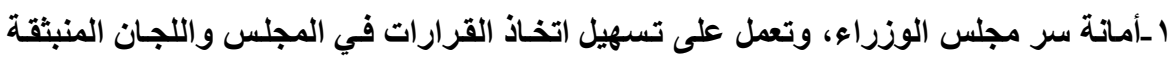

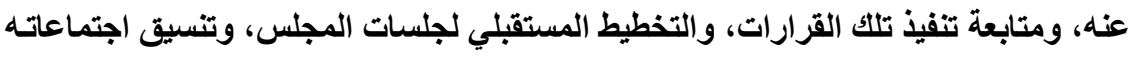

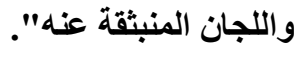


هذه المسألة من المسائل التي ينظمها العرف، والتي درج عليها مجلس الوزراء منذ قيامه، إذ اعتبرت المحكمة أن تغييب احد الوزراء عن حضور الجلسات التي صدر فيها

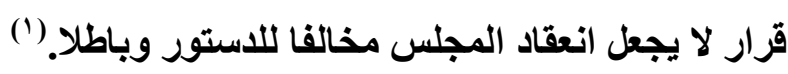
وتأسيسا على مـا سبق فأن قرار مجلس الوزراء يجب أن يصدر صحيحا من

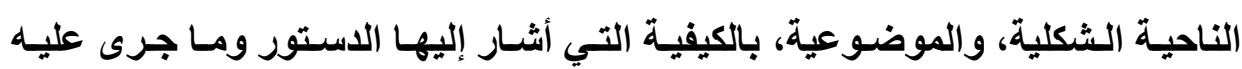
العرف الاستوري في آلية الانعقاد.

ونجد أن المشرع الدستوري الأردني قد أحسال فيما يتعلق بباقي الإجراءات إلى إلى

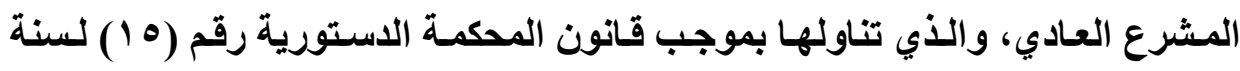

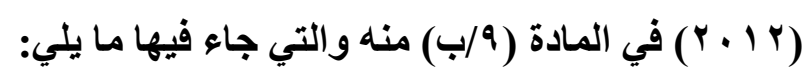
"إذا قررت إحدى الجهات المحددة في الفقرة (أ) من هذه المسادة الطعن في

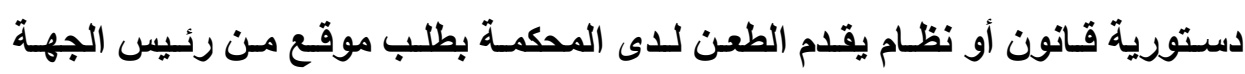
الطاعنة على أن يبين فيه ما يلي:

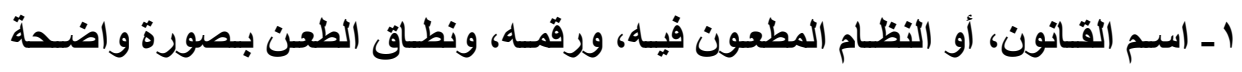

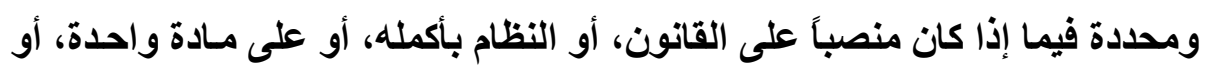

وبنـاءا على مـا جـاء في المسادة (9/ب) ســالفة الـذكر مـن قـانون المحكمـة اللستورية، وبعدما يصدر القرار من قبل مجلس كل جهة من الجهات الثُلاث صحيحا، 
ومستوفيا لجميع شروطه الثكلية، والموضوعية التي تطلبتها التشريعات ذات العلاقة، يجب أن يتم تقليم الطلب من قبل رئيس المجلس، على أن يحتوي هذا الطلب على اسم القانون، أو النظام الطعين، سواء كان التشريع كاملاً، أو إحدى النوصوص أو أو أكثر في

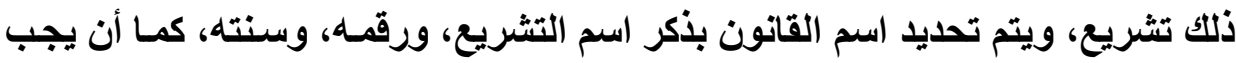
أن يذكر في صحيفة الطعن وجه المخالفة الستتورية التي قد اعترت التشريع الطعين بشكل واضح ومفصل، وهي أمسا أن تكون مخالفة شكلية، أو مخالفة موضوعية، ولا يجوز الخروج عن اوجه المخالفة المحددة حصرا كما اجمع عليها الفقه الدستوري، (') أو إغفال ذكرها، أو الإثارة إليها بشكل عام، وبخلاف هذه الشروط يتم رفض الطعن، كما لا يجوز أن يقدم الطعن على أساس احتمال وجود شبهة دستورية فقط دون تحديد

كما يقوم المكتب الفني للاى المحكمة الاستورية باستلام هذه الطعون، ويقوم بقيدها في سجل خاص لذلك، ومن ثم عرضها على رئيس المحكمة الاستورية، وتزويد

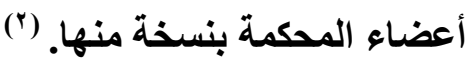

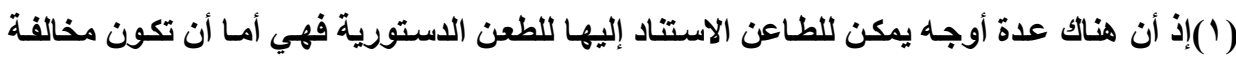

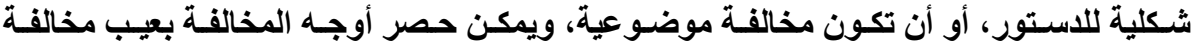

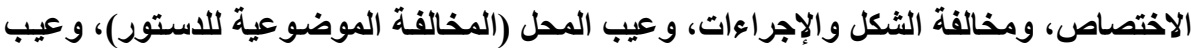

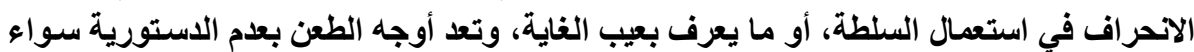

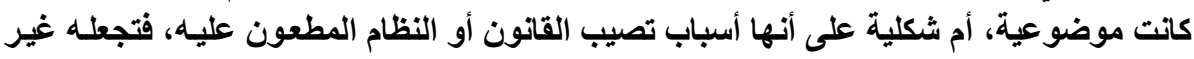
دانتوري.

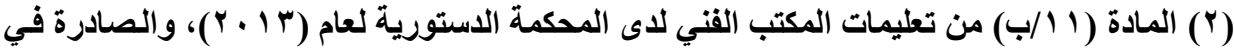

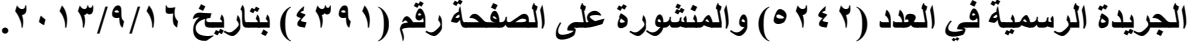


كمـا يقوم المكتب الفنـي للدى المحكمة الدستورية بعد قرار رئسيس المحكمـة الاستتورية بإسسال نسخة من كل طعن يقدم إلى رئيسي كل من الجهتين الأخريين

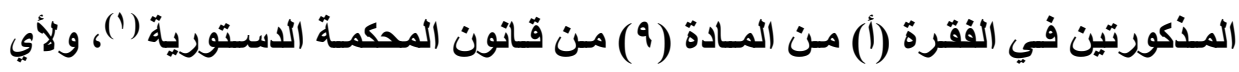

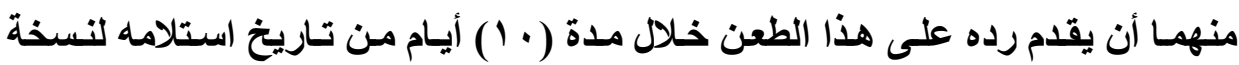

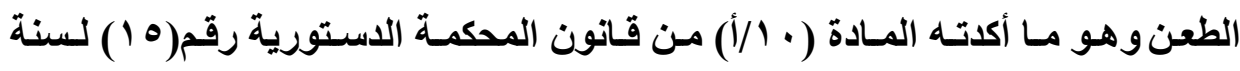

(r).$(r \cdot 1 r)$

وعند استعراض نص المادة ( • //أ) من قانون المحكمة الاستورية الأردنية نجد أن المشرع استخدم لفظ "ولأي منهما أن يقدم رده للمحكمة خلال عشرة أيام من تاريخ التاريخ

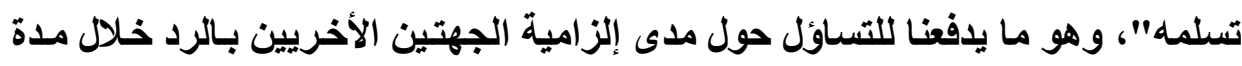
العشرة أيام هذه؟ بالإضافة إلى ما التساؤل حول الجزاء المترتب على هلى هذه الجهات في الجنائ

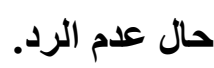

وبالنظر إلى الصياغة اللغوية التي جاء بها المشرع الأردني في المسادة (• الأ)

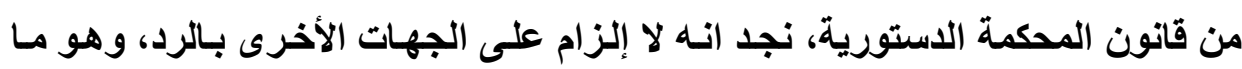
يفهم من سياق النص، إذ أن لفظ "ولأي من منهمـا" يفيد التخيير دون الإلزام لهذها

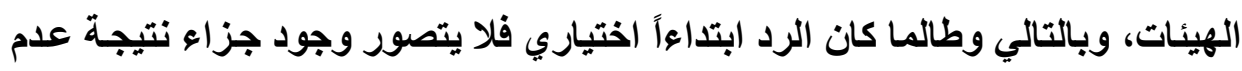

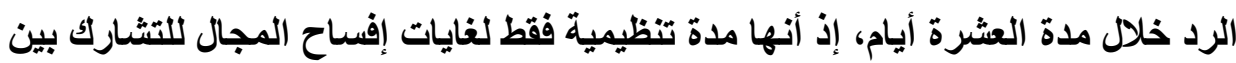
هذه الهيئات، ولإبداء رأيها حول هذا الطعن.

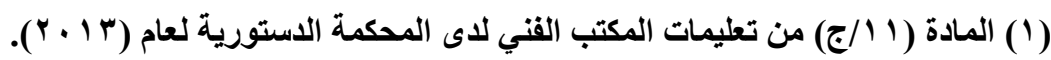

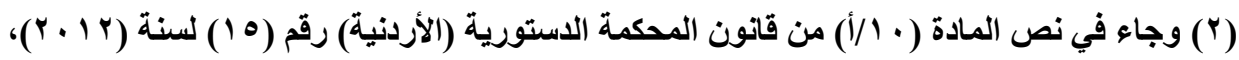

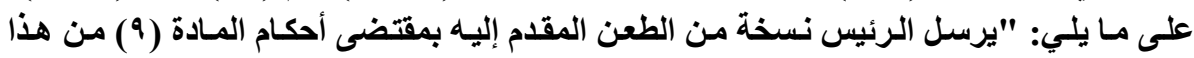

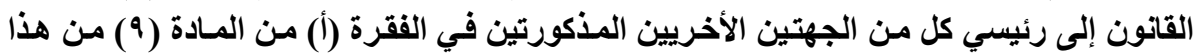

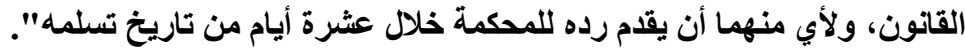


وتكون مسألة استلام الردود وعرضها على المحكمة من وظيفة المكتب القني

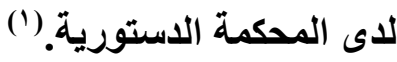

وقد أشارة المادة ( • ا/ب) إلى أن المحكمة الدستورية ملزمة بالفصل في الطعن

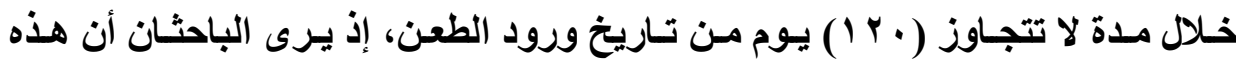
المسألة تنظيمية أيضا؛ لما لهذه الطعون من خصوصية نتيجة ارتباطها بالاستور حامي

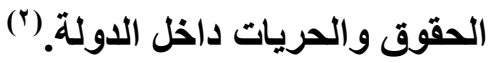
لكن ما هو الجزاء على تجاوز هذه الددة والتي حددها القانون بمائـة وعشرون يومـا؟ الإجابة تكون بـالنظر إلى طبيعة هذه المدة، ويالتالي فلا جزاء على مخالفتها لكونها مسألة تنظيمية للمحكمة. وفيما يتطق بميعاد تقليم الطعن المباثر فاننا نرى أن هذه الجهات غير مقيده

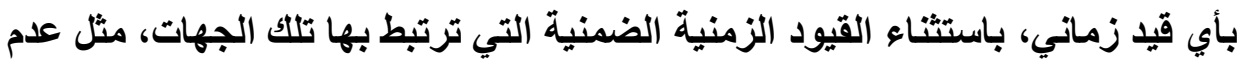
صلاحية مجلس النواب، أو الأعيان، لتقيم طلب الطعن في غير دورات الانعقاد العادية،

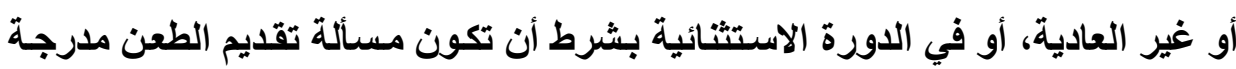
على جدول أعمال هذه الاورة الاستثنائية.

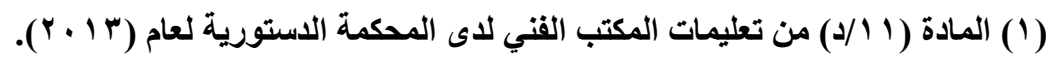

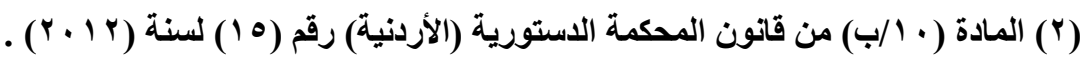

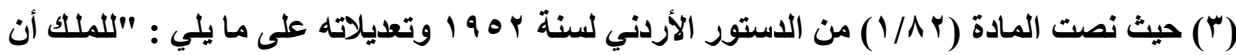

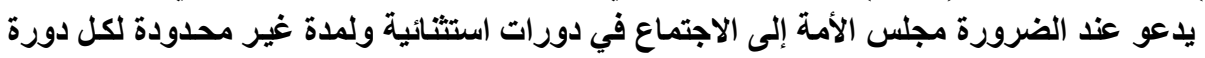

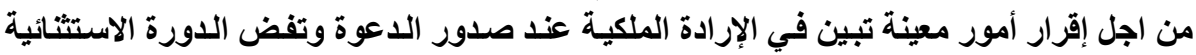


ونلاحظ أن المشرع الأردنسي لم يبين مدى إلزام المحكمة بمـا تقدمه الجهتين الأخريين حول الطعن المقدم بعدم الاستورية، حيث اكتفت المـادة (• //ب) من قانون المحكمة الاستورية بالإشارة إلى ذلك دون أن تثثير إلى مدى إلزام المحكمة بالأخذ بمـا

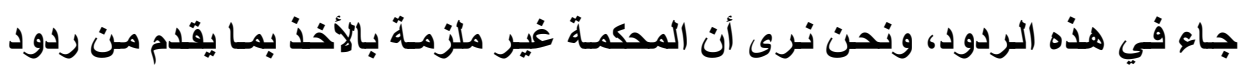

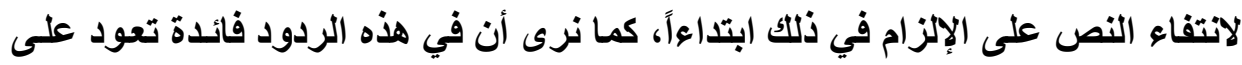
المحكمة من خلال بيـان كافة أوجه التشريع الطعين، ووجهات النظر المختلفة حولهه، مما يساعد المحكمة على الإحاطة بشكل اكبر بما يحمله من أحكام، وبيان مدى مخالفته للاستور بثكل اقرب إلى الصواب. 


\section{البمث الثاني \\ الدفع الفروي}

تعد الرقابة القضائية بطريق الافع من أقدم صور الرقابة الدستورية، وجزء لا

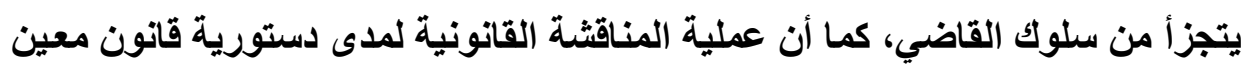

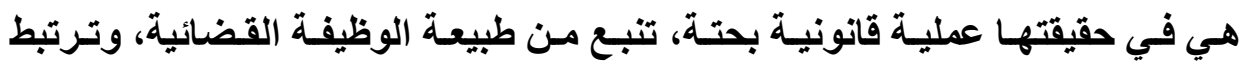

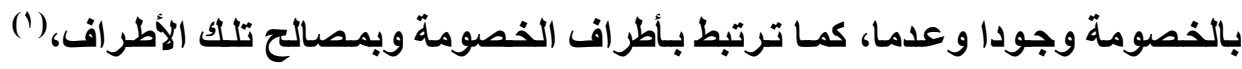

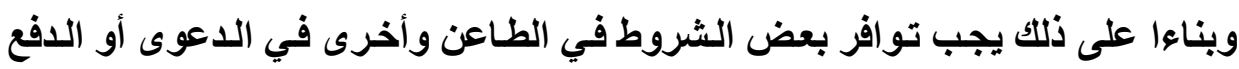

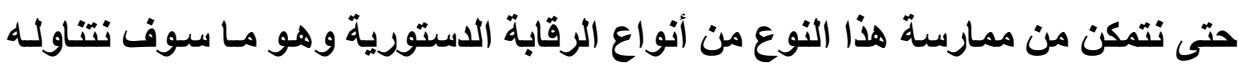
من خلال المطلبين التاليين: المطلب الأول: شروط الدفع الفرعي، أمسا المطلب الثاني: الإجراءات العملية للافع الفرعي.

المطلب الأول: شروط الدفع الفرعي: يعتبر الدفع بعدم الاستورية من الدفوع

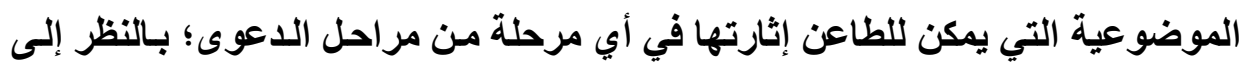
تعلق هذا الدفع بالنظام العام، كما انه دفع قانوني يمكن إثارته أمسام المحساكم العليا لأول

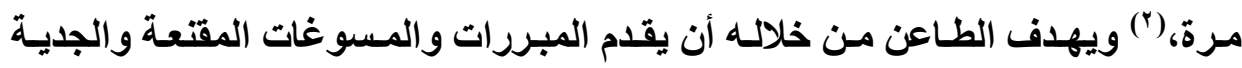

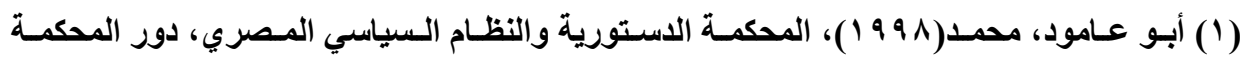

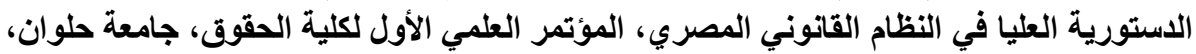

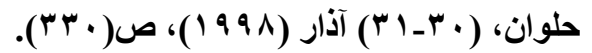

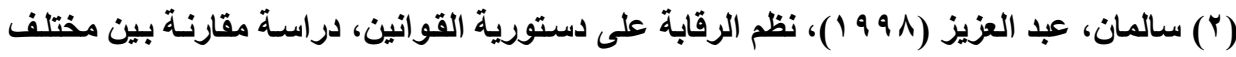

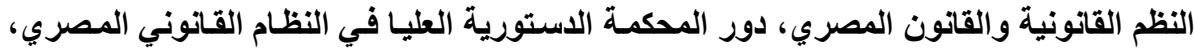
$=$ 
لالثبات حالة عدم الدستورية وزعزعة قرينة الدستورية في النص الطعين (')وبناءا على

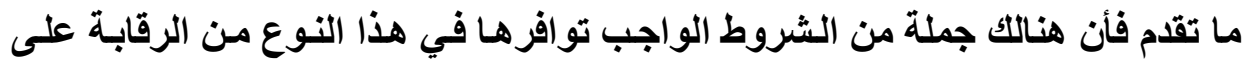
دستورية القو انين و الانظمة تتمثل بما سوف نورده في الفروع التالية:

\section{الفرع الأول: أن يكون الطاعن طرناً في دعوى هنظـورة أهـام المكمهـة: إذ}

يتوجب على الطاعن ابتداءا أن يكون طرفاً في الدعوى المعروضه أمسام المحكمة، على الئ

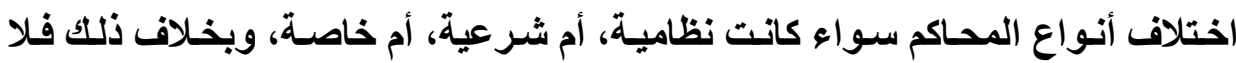
يجوز تقديم الدفع الفرعي تحت أي حال من الأحوال. ويخرج عن هذا الوصف كل طرف في الدعوى (عدا الخصوم) كما هو الحال في الثهود، إذ أن وجودهم في الدعوى عرضي فقط ينقضي بانقضاء الغاية منه. ونحن نرى أن في اشتراط أن تكون الدعوى منظورة الكثير من المشقة على الطاعن، وتعقيدا غير مبرر للإجراءات، ونفترض مثلا أن من ينوي الطعن ابتداعاً كان

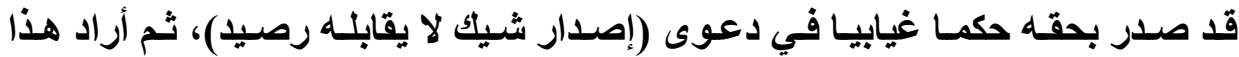
الطاعن أن يقدم طعنه الفرعي بنص المـادة ( آ؟) من قانون العقوبات والتي تناول النص على هذه الجريمة، ونظرا لكون هذه القضية غير منظورة يتوجب على الطاعن

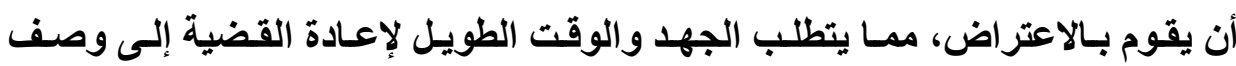
"منظورة"، ومـن ثم يقوم بتقديم دفعه الفرعي من خلال وكيله بحسب الإجراءات

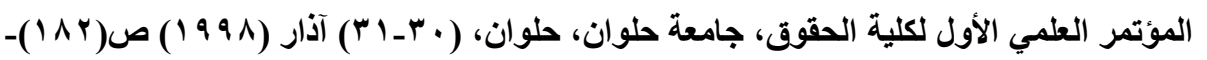

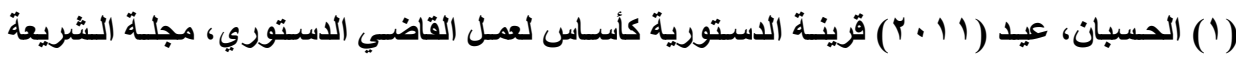

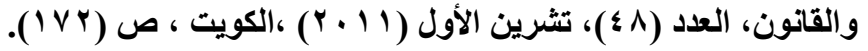

مجلت البحوث القانونيت والإقتصاديتة مه 10 
المحدة في الدستور والقانون، وهو الأمر الذي نرى فيه انتقاد كبيراً للمشرع، إذ كان الأجدر بالمشرع أن يضع شروطا أيسر على الطاعن بحيث يراعي مثل هذه المسائل. كما يخرج من هذا الإطار مـا يتعلق بهيئات التأديب، ومـا يحكمها من أنظمـة وقو انين أثناء ممارستها لوظائفها المختلفة، وذلك لانتفاء وصف المحكمة عنها. كما نثبير هنا إلى أن الدفع بعدم دستورية أي نص قانوني أمسام المدعي العام ليس له أي سند قانوني، إذ أن المدعي العام هو قاضي تحقيق، وليس قاضي الموضوع

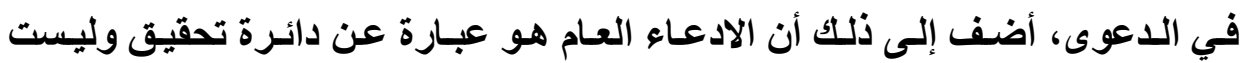
محكمة، بما يخرجها عن الوصف الذي تطلبه القانون.

\section{الفرع الثاني: ان يقوم الطاعن بتقديم طعنه هـن خسلال هـام أسستاذ:}

ونلاحظ أن المشرع الأردني هنا قد اشترط أن يتم تقديم الطعن (الدفع الفرعي) من خلال

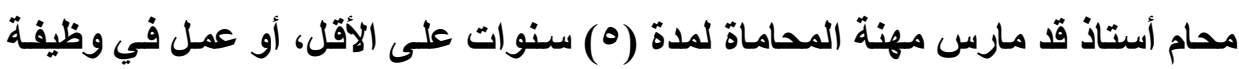

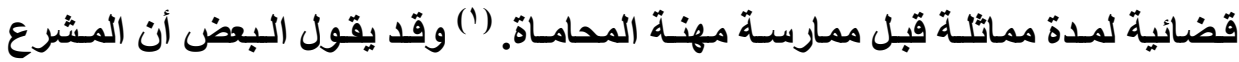
الأردني لم يتطلب هذا الثرط ابتداءا إلا فيما يتعلق بموضوع تقديم المذكرات للمحكمة

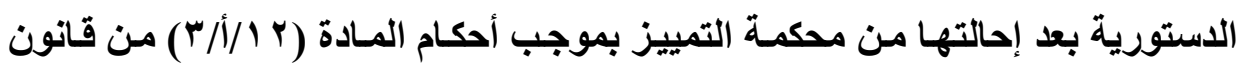

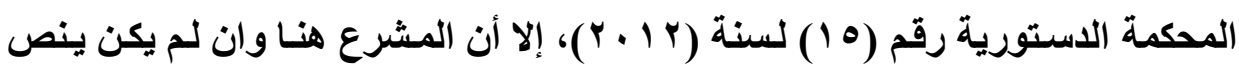
على ذلك صراحة في القانون إلا أن هذا الشرط يمكن استتنتاجه من بـاب المنطق

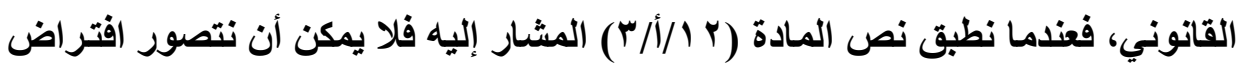

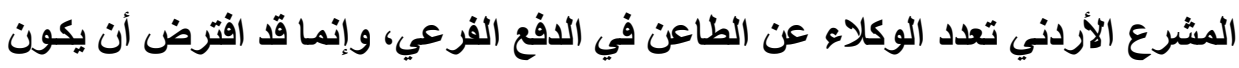

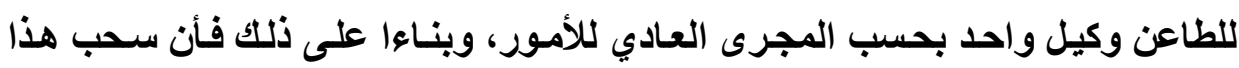

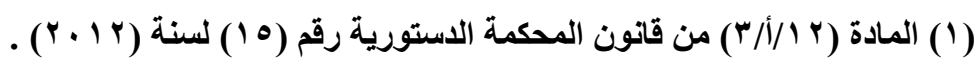

مجلتّ البحوث القانونيت والإقتصاديت ه هـ 
الوصف الذي أشارت إليه المـادة (ץ //أ/\%) يتفق مـع الفهم الصحيح للنص القانوني، و القول بخلاف ذلك يؤدي إلى نتائج غير منطقية، ومستهجنة. ونحن بدورنا نـاعوا المشرع الأردني للنص صراحة على هذا الأمر، وذلك

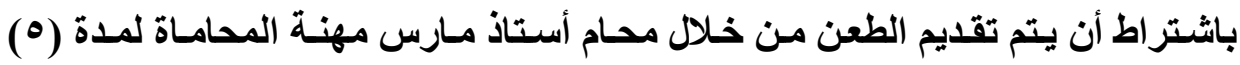
سنوات على الأقل، أو عمل في وظيفة قضائية لمدة مماثلة قبل ممارسة مهنة المحامـاة، وذلك لتلافي الوقوع في لبس حول هذه النقطة التي اشرنا إليها. ويرى الباحثان أن هذا الشرط ضروري لغايـات الاستفادة من الخبرة العملية الموجودة للى المحامي الأستاذ في هذا المجال، أو لمن عمل في وظيفة قضائية بنفس هذه المدة، وذلك لإعداد صحيفة طعن خالية مـن العيوب الشكلية أو الموضوعية، ولغايات السرعة في البت في الطعن، وعدم الدخول في إثكاليات لا حاجة لها.

الفرع الثالث: الوكالة الخاصة لغايات الطعن بعـدم الدسـتورية: ونشير إلى أن هذا الثرط لم يتم النص عليه بشكل صريح في الدستور الأردني، أو حتى في

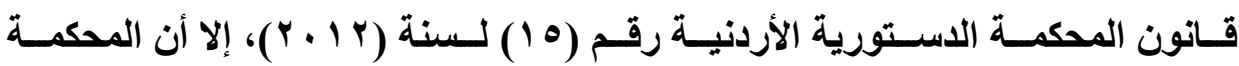
الدستورية الأردنية في بعض أحكامها أثدارة إلى ضرورة توافر هذا الثرط بالنظر إلى الى

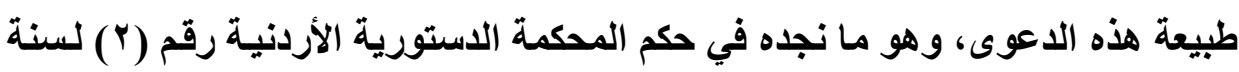

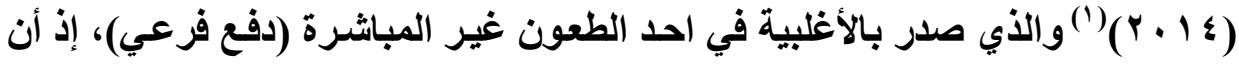


الحكمـة اشترطت أن يتم تنظيم وكالة خاصة من قبل الطـاعن لوكيله تتضمن الطعن

بعدم الدستورية.

(1) وجاء في حكم الإجماع ما يلي: "وقد جاء في قرار الأغلبية ما يلي:

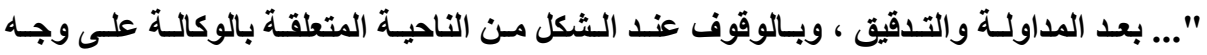

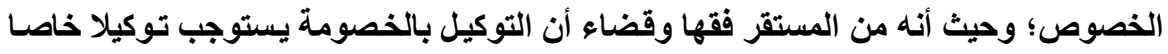

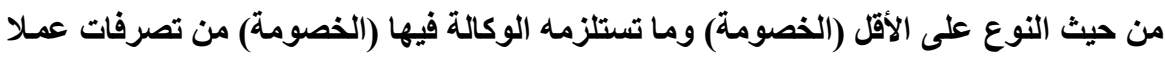

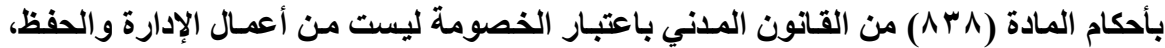

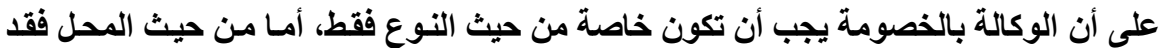

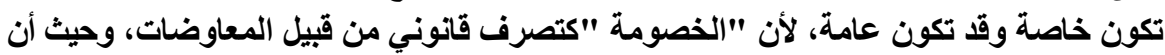

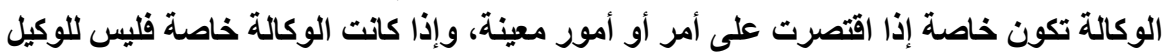

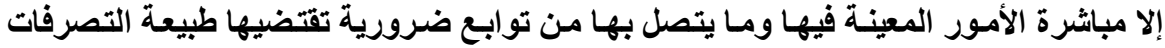

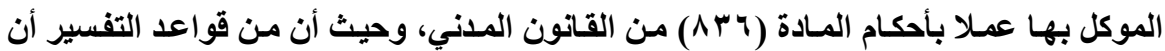

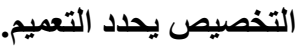

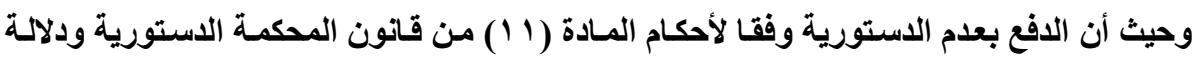

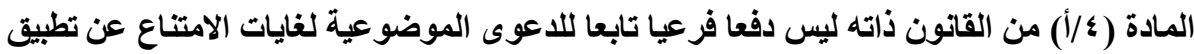

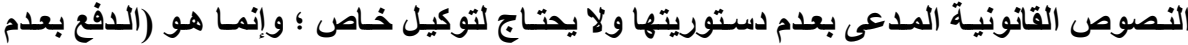

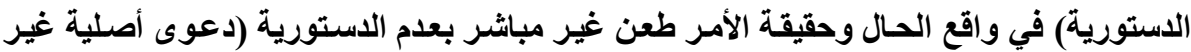

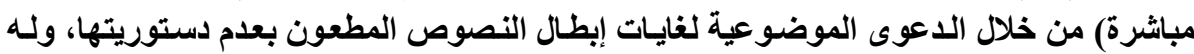

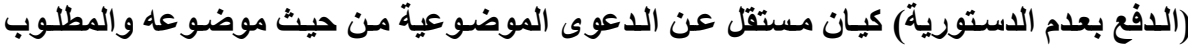

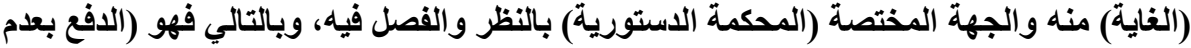

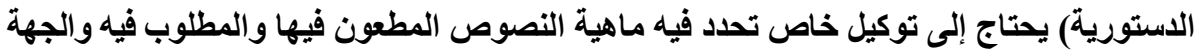

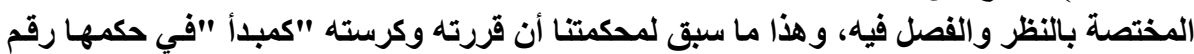

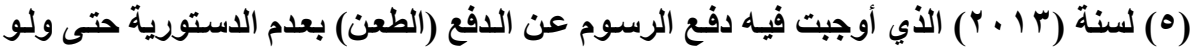

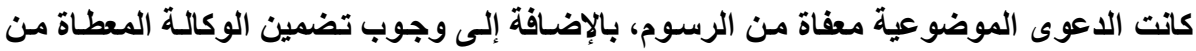

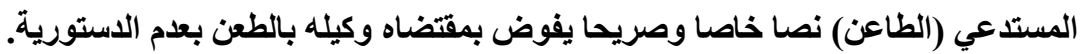

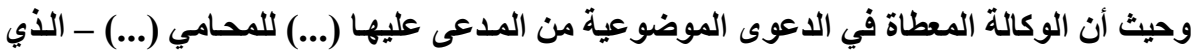

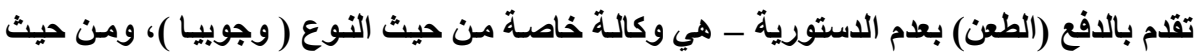

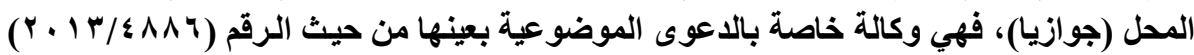
والجهة المدعية (...) والموضوع (طلب منع المعارضة والمطالبة بأجر المثل) والجهة المثرة المختصة $=$ 
ونحن بدورنا نؤيد ما جاء في قرار الإجماع المشار إليهه مـع عدم اتفاقتـا مـع مـا

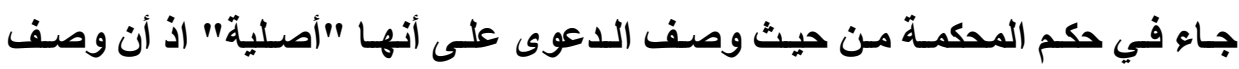
الأصلية لا يكون إلا في الدعوى، وبالتالي لا مجال للتساوي بين الدعوى والدفع إطلاقا، كما أن الدعوى الأصلية تقـام بدايتاً من صساحب المصلحة بشكل مباشر مخاصمتاً فيهـ القانون، أو النظام، المخالف للاستور طلبً في إلغاءه، في حين أن الدعوى الفرعيـة لا تكون إلا بوجود دعوى أصيلة مرتبطة بها. وعلى الرغم من ذلك فأنتا نقار ما ساقه الرأي المخالف من حجج وأسانيد لتأيد رأيه والأي تمثل بكفاية الوكالة الخاصة المتعلقة بالدعوى الموضوعية لتغطية مسألة الطعن بعدم الاستورية من خلال الافع الفرعي. (') الفرع الرابع: أن يكون القـانون أو النظــام واجـبـ التطبيـق : وقد اشترط

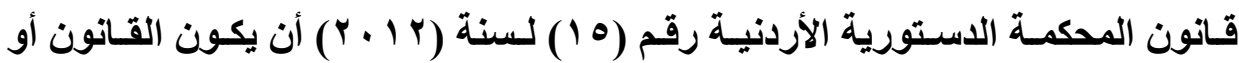

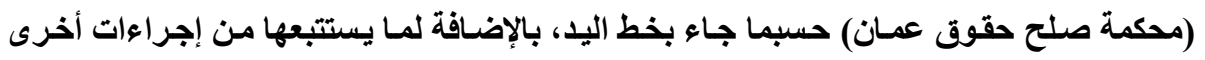

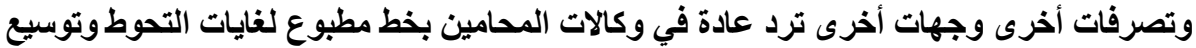

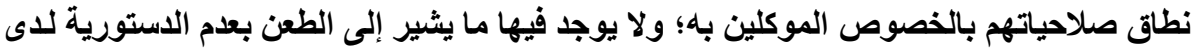

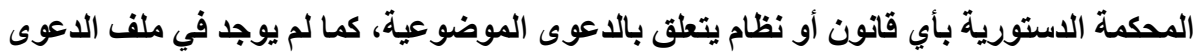

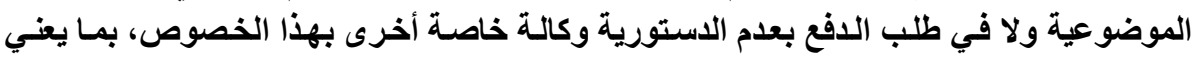

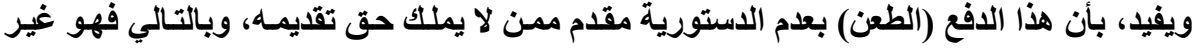

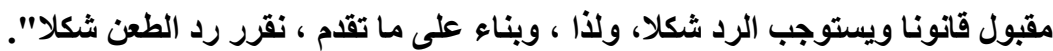
(1) لطفا، انظر قرار المخالفة الصادر عن عضو المحكمة الاستورية محمد الغزوي في حكم المحكمة

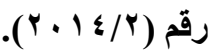




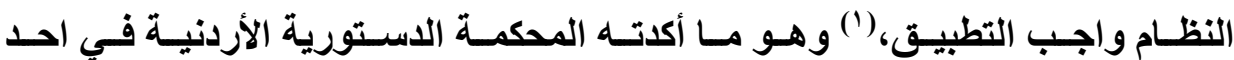

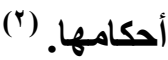

وبالتالي لا يجوز للطاعن في الدفع الفرعي أن يطعن إلا في نصوص القانون، أو

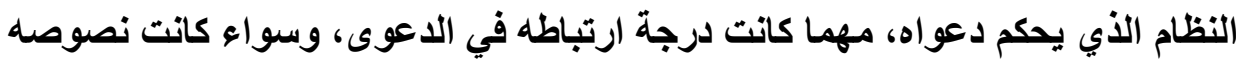
موضوعية، أو مجرد نصوص إجرائية فقط.

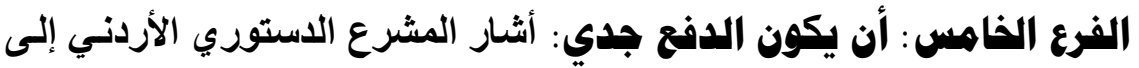

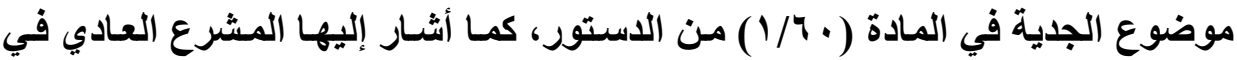

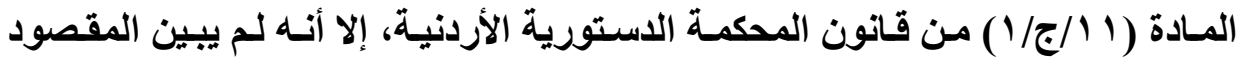
بهذه الجدية، ولا قرائن وجودها، مما يجعلها من المسائل الخاصة بعمل القاضي، وهو ما نجده أيضا لاى المشرع المصري في قانون المحكمة الاستورية العليا، إذ أنها لم لم يبين المقصود بمفهوم الجلية أيضا، والتي أثشارث إليها المـادة (و ؟ب/ب) من قانون المحمة الاستورية العليا. (")

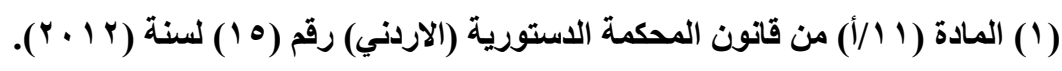

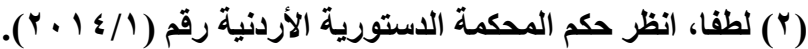

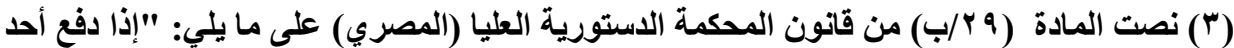

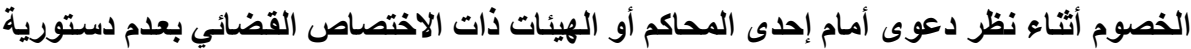

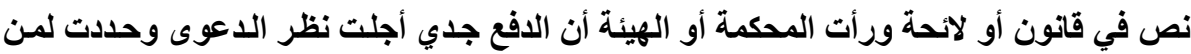

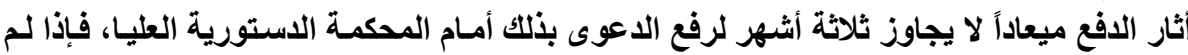
ترفع الاعوى في الميعاد اعتبر الدفع كأن لم يكن".

مجلم البحوث القانونيتة والإقتصادية ب به 
ويرى جانب من الفقـه أن الدفع حتى يكون جديا يجب أن لا يكون الهـف منـه

أطالة أمد التقاضي، والذي يكون غير مؤثر في الدعوى. (')

كما يرى جانب من الققه أن جدية الدفع هي أن يكون القانون، أو النظام الذي اعتراه شبة عدم الاستورية متصلا بموضوع الاعوى القائمة، أي من الممكن أن يطبق هذا النص غير الدستوري على الدعوى على أي وجه من الوجوه، وأن يكون هنايك شك في دستورية القانون، أو النظام المطعون في دستوريته، ويفسر الثك لجانب عدم

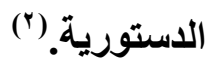
في حين يرى جاتب آخر أن الجدية لا تكون إلا عندما يكون الفصل في الدفع ذو تأثير على الفصل في الاعوى الموضوعية، كما يؤدي إلى إثارة الشك في نفس قاضسي الموضوع من وجود شبهة عدم دستورية حول المسألة المثارة أمامه.(") كما يرى جانب آخر من الفقه أن جدية الدفع هي أن يتحقق قاضي الموضوع من أن الدفع لا يقصد منـه الكيد أو إطالة أمد التقاضـي، بـأن يكون الفصل في هذا الدفع منتجا، ويتصل بموضوع النزاع، ومحتمل التطبيق على النزاع في الدعوى الأصلية، كمـا أن الحكم بعدم الاستورية سيفيد منـه الخصم في الدعوى الموضوعية المنظورة

(1) (الباز، سيد (9^v (1) )، الرقابة على دستورية القو انين في مصر، ، دراسة مقارنة، الطبعة الأولى، دار

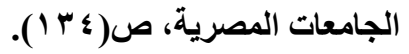

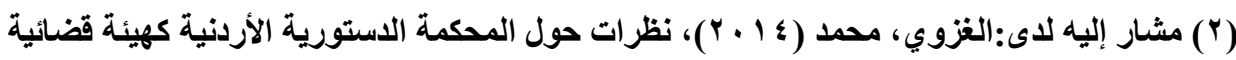

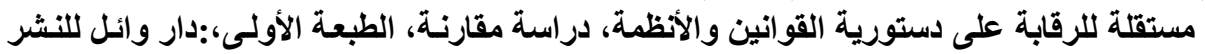

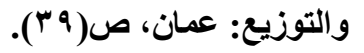

(r) فوزي، صلاح الدين (ب 9 9 1)، الدعوى الاستورية، دون رقم طبعة، دار النهضة العربية: القاهرة،

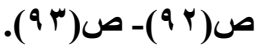


أمام المحكمة، بالإضافة إلى وجود خلاف في تأويل النص الطعين ممـا يثير فيه شبهة

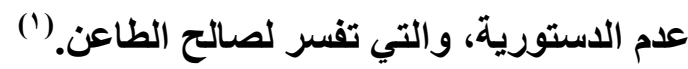
ومؤدى ذلك أن القاضي إذا مـا وجد أن هذا الدفع يخرج عن حيثيات اللاعوى ومجرياتها يتوجب عليه الالتفات عما جاء فيه، وان يصدر قراره بـان بالرفض، ويستأنف القاضي مجريات الدعوى من النقطة التي انتهت إليها من قبل. ونحن نرى أن الدفع الجدي هو بنـاء الطاعن لدفعه الفرعي على أسساس الظن

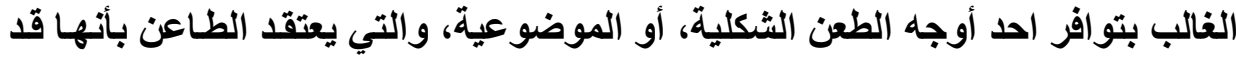
أصابت القانون، أو النظام الطعين، مع كون هذا القانون أو النظام واجب التطبيق على الطى

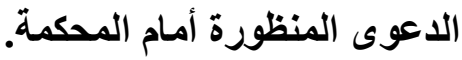
ونثير هنا إلى أمر في غاية الخطورة، إذ أن المحكمة وهي بصدد تقدير مدى

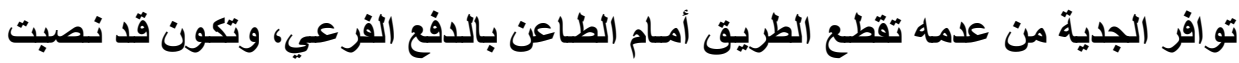
نفسها في تلكك الحالة بليلة عن المحكمة الدستورية صاحبة الاختصاص الأصيل في ذلك.

كما ونوجـه ذات الانتقاد الأخير لكل من محكمة التمييز، ومحكمة الاستئناف، و المحكمة الإداريـة، في حسال استتنـاف قرار الرفض وذلكك عندما تقوم هذه المحسكم بفحص مـدى الجديـة مـرة أخرى، والذّي نـرى انـهـ تغول على صـلاحيات المحكمـة الاستورية، إذ لا حاجة لوجود مثل هذا الإجراء. 
كما أن المحكمة وهي بصدد إعمـال صلاحياتها في تحديد الجديـة لا تركن إلى أساس متين يمكن من خلاله بيان عناصر وأركان الجدية بثكل قاطع، و إنما كل مـا جاء به الققه في هذا المجال لا يعدو كونه اجتهادات قد يختار القاضي بعضها ويففل الآخر،

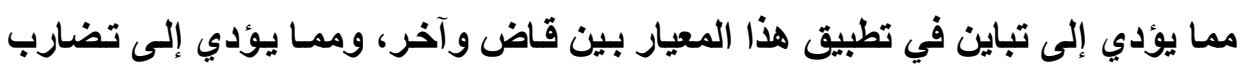
في الأحكام القضائية الدستورية. وقد يحدث أن يصدر قرار من قبل احد القضاة في دعوى معينة بقبول الدفع، وإحالة الدعوى إلى محكمة التمييز لتوافر شرط الجدية، في حين انه في دعوى أخرى لذات الدافع وبذات الموضوع قد لا يقبل فيها قاضي الموضوع الدفع بالاستناد لعدم الجدية، بغض النظر عن النتيجة النهائية، والتي سوف تشمل الدعويين بالمحصلة، إلا أن الفكرة في ذلك تكمن في التباين في تطبيق هذا المعيار من قبل القضاء، والذي يتطلب من المشرع أن يتذخل ليحدد معالم هذا الثرط على نحو قاطع. وفي حال صدر قرار قاضي الموضوع برفض الدفع لعدم الجدية أو لغيرها من الأسباب الثكلية التي يشترط تو افرها في المذكرة التي يقدمها الطاعن، فأن للطاعن أن يتقدم بالطعن بقرار الرفض بالطريقة التي يطعن فيها بالدعوى ذاتها، وهو ما يدخلنا في إثكالية جديدة تتمثل بإمكانية حرمان الطاعن من حقه في الطعن مرة أخرى في حال كاتت الدعوى لا تقبل الطعن بالطرق العادية لاى أي جهة استننافية أعلى. ونحن نرى انه من الممكن للمشرع الأردني أن يعمل على حل هذه الإثكالية من

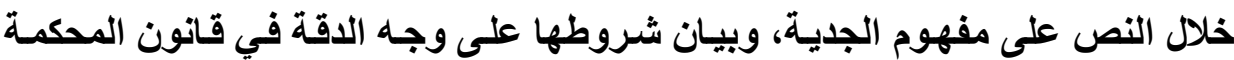
الدستورية بحيث يرتكز القاضي في هذا الأمر إلى القانون بلا من الاجتهاد في ذلك لما لهابل

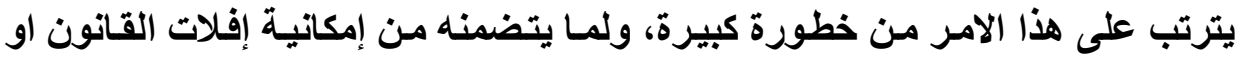


النظام المخالف للاستور من الرقابة في حال اخطأ القاضي في الاجتهاد لتقدير مدى

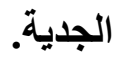

و الحل الأخر في نظرنا يكمن في إنثاء لجنة مختصة تابعة للمحكمة الاستورية

يتم من خلالها فحص مدى الجدية بالاستناد إلى وجود نص قانوني يبين ماهية الجدية

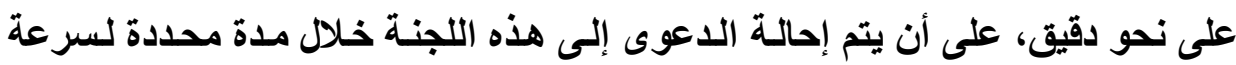

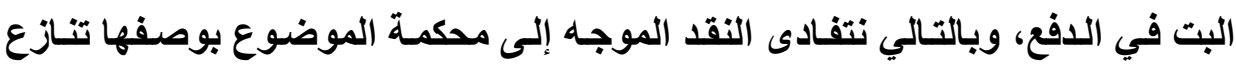
المحكة الدستورية في اختصاصها، كما نحل مشكلة عدم التحديد لمفهوم الجدية من الناحية التشريعية، ونجعل مسألة تحديدها يصدر من رحم المحكمة نفسها بلدا من أن يترك الأمر لاجتهادات القضاة وتقديراتهم المتباينة لمعنى الجدية. وقد عبرت محكمة التمييز الموقرة عن رأيها حول معيار الجدية في الدفع إذ

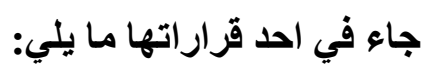
"...وحيث أن محكمتا صاحبة الولاية لإحالة الطعن إلى المحكمة الدستورية أو رفض ذلك فإنتا نرى أن من شروط إحالة الطعن أن تكون هناك دعوى قائمسة وأن يكون الطـاعن قد تقدم بمـكرة خطية يبين فيها أسباب طعنـه، من حيث استبعاد القـانون

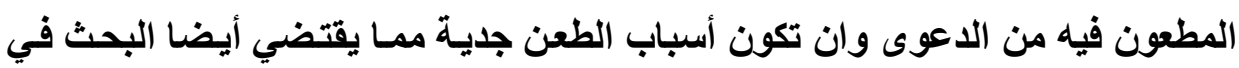
مصلحة الطاعن كعضصر أساسي في جدية الطعن ومؤدى ذلك أن تلكك الأسباب بظاهرها

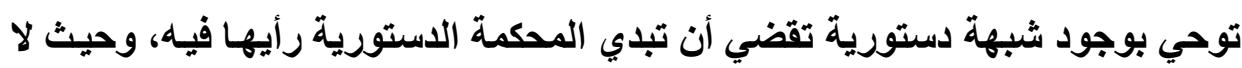

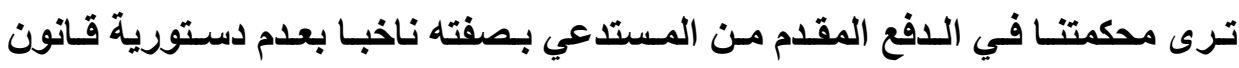


الانتخـاب بالجدية من جهة، وانتفاء المصلحة من جهة أخرى فتقرر محكمتـا رفض (المض الطلب بإحالة الأوراق إلى الدحمة الدستورية وإعادة الأوراق إلى مصدرها".(') وقد عبرت المحكمة الاستورية الأردنية عن مفهوم الجدية في إحدى أحكامها

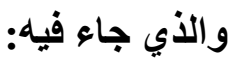
"... وبذلك فإن الدفع بعدم الاستورية أمام الححاكم على اختلاف أنواعها يستلزم

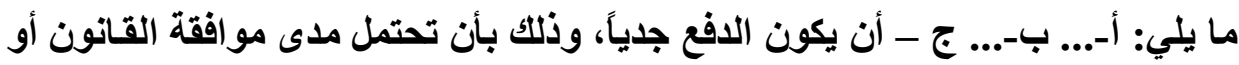

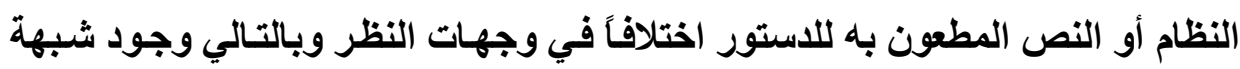
بتعارض القانون، أو النظام، أو النص مـع أحكام الدستور، أمسا إذا ثبت للمحكمة على وجه اليقين أن النص المطعون به واضح وأنه ليس هناك بالتالي شبهة في دستوريته

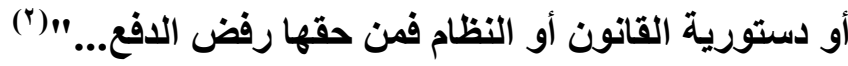
ومن تطبيقات المحكمة الدستورية حول الإثـارة إلى توافر الجدية مـا ورد في إحدى أحكامها و الذي جاء فيه:

"... وحيث أن الطلب المقدم من رئيس مجلس النواب تضمن البيانات الجوهرية التي تكثف بذاتها عن ماهية المسألة الدستورية التي يعرض على المحكمة أمر الفصل

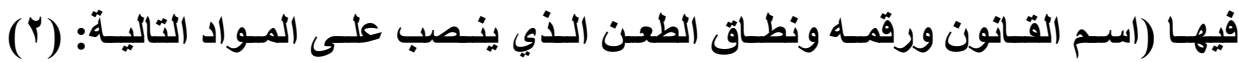

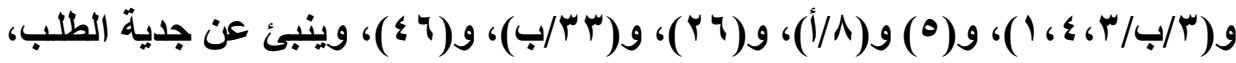

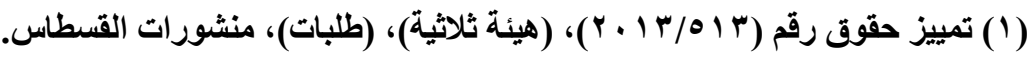

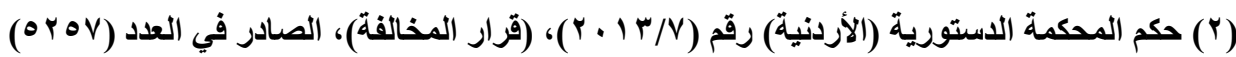

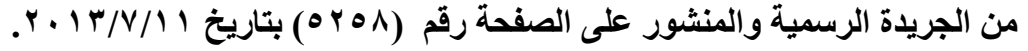


ويتحدد بها موضوعه بشكل كـاف، وبخاصـة أن مثل هذا الطلب المقدم يحمل بذاتـه

وبحكم طبيعته قرينة الجدية...". (1)

وبالعودة للمشرع المصري والذي أثـار إلى طريق الدفع الفرعي في المسادة

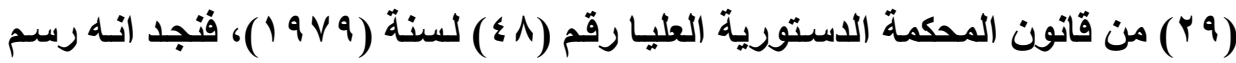
هذه الطريق في أيسر صورها وأسهلها على الطاعن، اذ لا يتوجب على الطاعن إلا أن يقوم بتقليم الطعن للمحكمة ذات الاختصاص القضائي بصدد دعوى موضوعية مقامـة ابتداعاً أمام إحدى المحاكم أو الهيئات ذات الاختصاص القضائي، وفي حال ثبت لمحكمة الموضوع جدية الطعن فأنها توقف النظر في الدعوى مؤقتا، وتحدد للطاعن فترة زمنية يتوجب عليه خلالها أن يقوم برفع دعواه أمام المحكمة الاستورية العليا. كما أن هذه المدة يجب في جميع الأحوال أن لا تجاوز مدة (ّا) أشهر، إذ أنها تعتبر مدة سقوط، ولا يستطيع الطاعن أن يقيم دعواه خارجها و إلا رد الدفع شكلا، كما

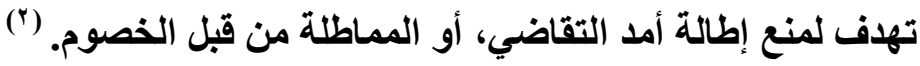
المطاب الثاني: إجراءات الـدفع الفرعي: فبعد أن تتوافر الشروط المشار

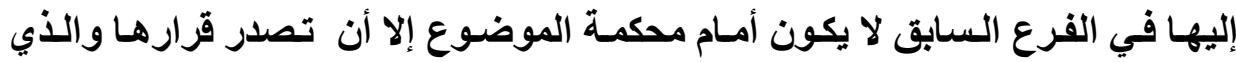

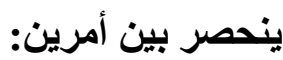

الأمر الأول: قبول الدفع إذا ما تراءى لها جديته، وبالتالي تقوم بإحالة الدعوى إلى محكمة التمييز، بعد أن توقف النظر في الدعوى مؤقتا إلى حين البت بالدفع من قبل

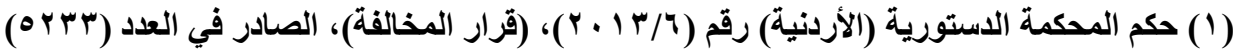

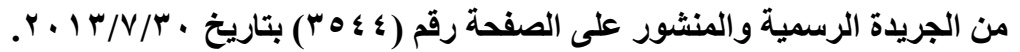

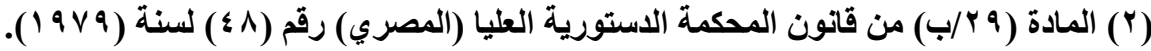


محكمة التمييز، أما بالنسبة للمحكمة الدستورية العليا المصرية فتقوم بإحالة الدعوى إلى المحكمة الاستورية العليا بشكل مباشر دون الدخول في هذه الإجراءات الطويلة

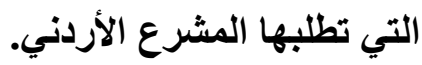
الأمر الثاني: عدم قبول الدفع إذا تراءى للمحكمة عدم جديته، وبالتالي تقرر

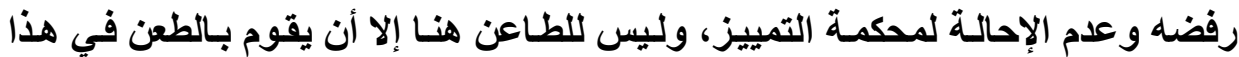
القرار بالطريقة التي يطعن فيها بموضوع الاعوى.

ونحن نرى أن من الواجب على قاضس الموضوع العمل على إحالة الدعوى

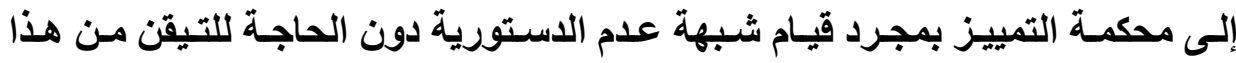
الثبهة، إذ أن دور القاضي هنا لغايات تقدير مدى توافر عيب عدم الدستورية في النص من عدمها بنـاءا على قرائن ثابتة وواضحة يمكن أن يؤسس قراره بالإحالة استنادا إليها.

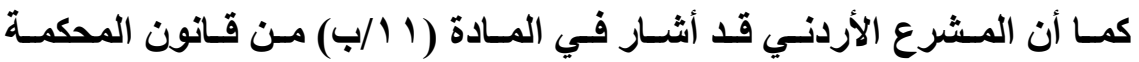
الاستورية إلى الإجراءات الثكلية الأخرى التي يتوجب على الطاعن القيام بها، وتتمثل

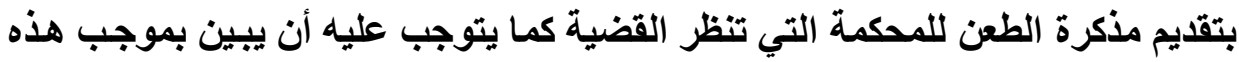

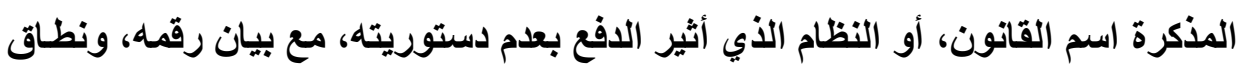

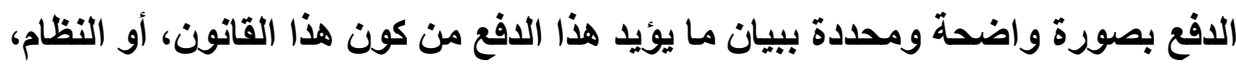

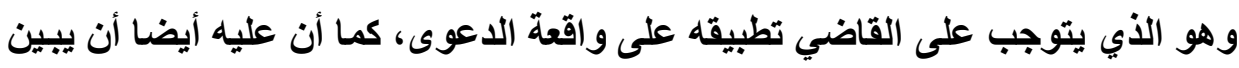

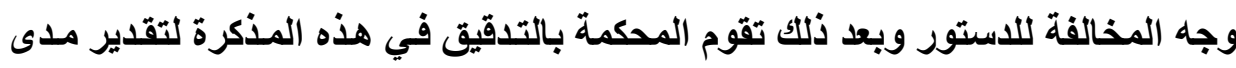

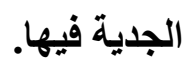


ويتوجب على قاضي الموضوع أن يصدر قراره خلال مدة (ه 1) يوم بثأن قبول الدفع من عدمه، ولا يجوز له تجاوز هذه المدة وألا أصبح قراره معيباً من حيث الشكل، كما يكون لكل طرف في الدعوى الحق بالرد من خلال وكيله على ما أثناره الطاعن فيما دفع به من عدم الدستورية خلال المدة التي تحددها محكمة الموضوع، على أن لا تزيد

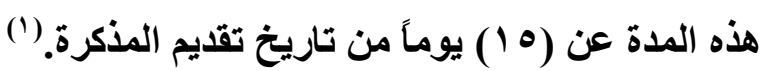
وبالتالي فمن حق وكيل كل طرف من أطراف الدعوى بمن فيهم ممثل الحق العام في بعض الدعوى أن يتقلم بمثل هذه المذكرة، ولا تقتصر على الأطراف فقط، بل تسري أيضا على وكلاء الدولة، إلا أن المشرع المصري لم يحدد مدة معينة للمحكمة للبت في

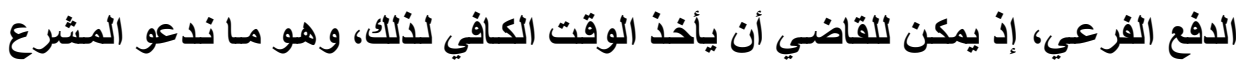

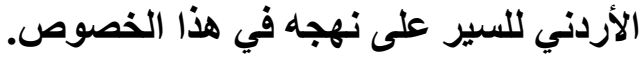
أمـا في حالـة مـا أذا صدر قرار قاضسي الموضوع بالموافقـة على الإحالـة، أو الرفض خارج المدة القانونية وهي مدة الخمسة عشر يومـا، فهنا لا بـ لنـا من البحث أولا في طبيعة هذه العدة أن كاتت تنظيمية، أو مدة سقوط حتى نتمكن من معرفة القيمة

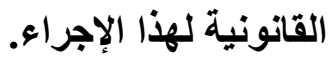
وللوهلة الأولى يبدو أن القرار قـ شابه من عيب شكلي أدى إلى بطلانه وبطلان

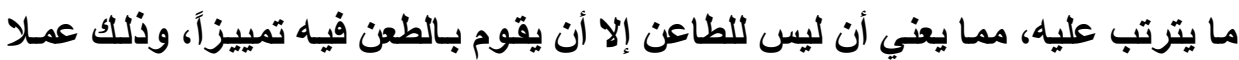




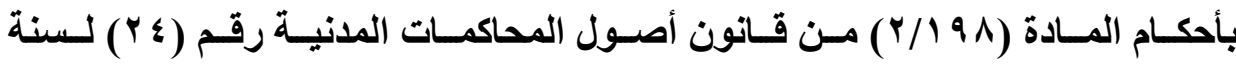
(') (1911)

إلا أنه وبعد مطالعة قانون أصول المحاكمات المدنية والتدقيق في النصوص ذات العلاقة وهو ما يطبق هنا بدلالة المادة (r I ) من تعليمات إجراءات الفصل في الطعون

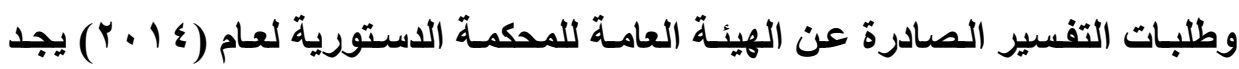

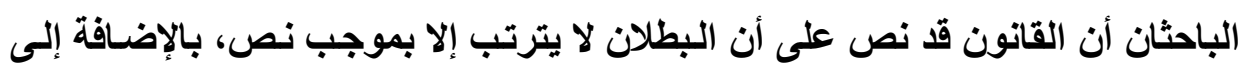

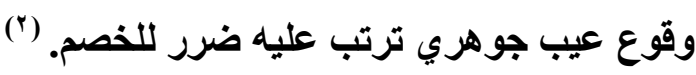
كما أن المشرع الأردني قد اشترط عدم التمسك بالبطلان، إلا لمن شرع البطلان لمصلحته، وليس لمن تسبب في البطلان أن يتمسك فيه عدا الحالات المتعقة بالنظام

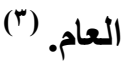
وأجـاز قـانون المحكمة الاستورية للأطراف تقديم مـكراتهم للرد على الدفع الذي قدمه الطاعن، إلا أنتا وبالرغم من ذلك نرى أن تقديم الرد على هذا الدفع من

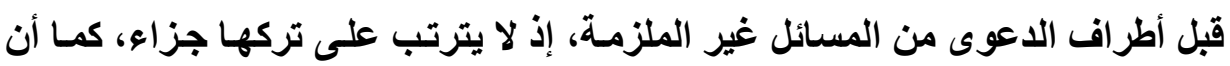

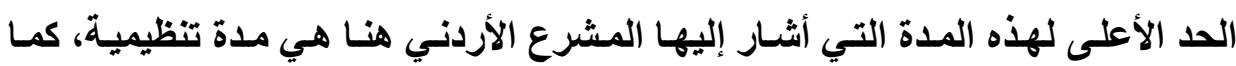

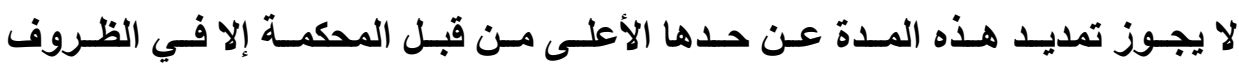
الاستثنائية.

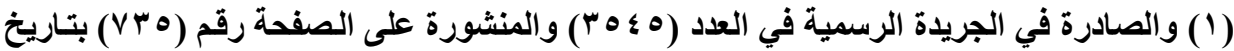

$$
\begin{aligned}
& \text {. } 9 \wedge \wedge / \varepsilon / \gamma
\end{aligned}
$$

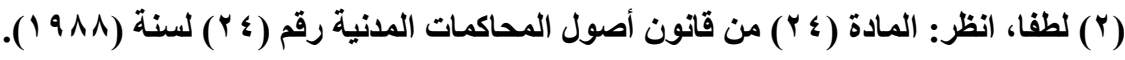

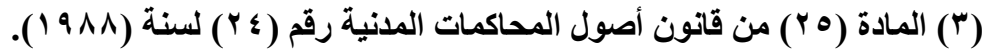

$$
\begin{aligned}
& \text { OVY مجلة البحوث القانونيت والإقتصاديت }
\end{aligned}
$$


كما أن قرار الإحالة المقدم في الدفع بعدم الاستورية قابل للطعن مع موضوع الاعوى، (') وهو ما يدفعنا للتفريق حيال هذه النقطة بين أمرين:

\section{أولا: أن تكون الدعوى الموضوعية تقبل الطعن بالطرق العادية.}

فعند صدور قرار من قبل محكمة الموضوع برفض الإحالة يجوز للطاعن أن

ينتظر إلى الوقت الذي يصدر بموجبه القرار في الدعوى الموضوعية، ويقدم طعنه بالترافق مع قرار الدعوى الموضوعية.

ويمكن هنا أن نتصور عدة سيناريوهات محتملة الوقوع في هذه النقطة، والتي

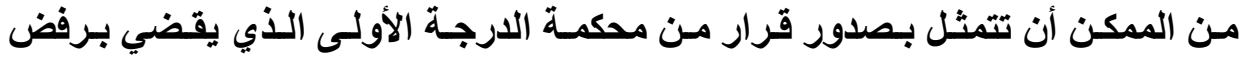
الإحالة، مما يدفع الطاعن إلى استنـاف قرار الرفض في تلكك الدعوى، ويصدر بناءا على هذا الاستنناف قرارا من محكمة الاستنناف التي تؤكد جدية الدفع، وبالتالي تقوم بإعادة الدعوى إلى محكمة الارجة الأولى، وهنا يمكن أن نتصور احد أمرين، الأول هو لالهو أن تقوم محكمة الارجة الأولى بالسير على هدي ما جاء في محكمة الاستثناف، وتصدار

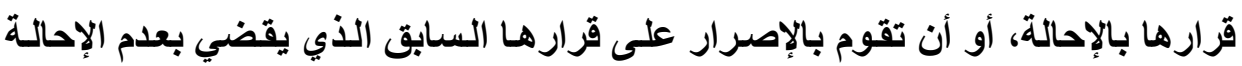

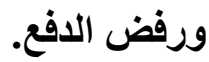

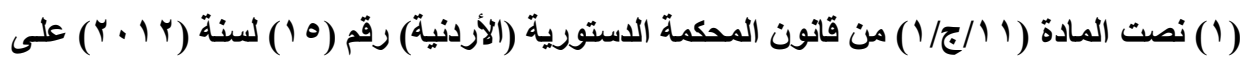

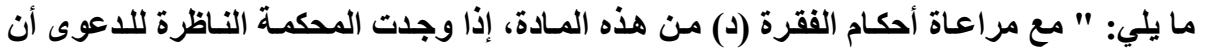

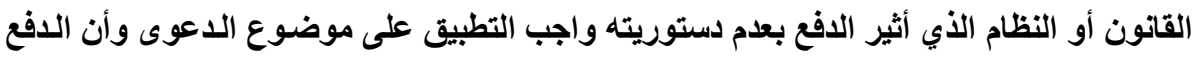

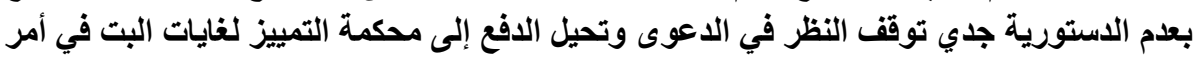

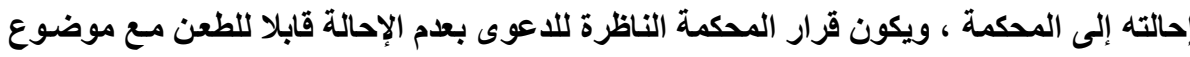


وبالرجوع إلى نصوص القانون ذات العلاقة في هذا الخصوص يجد الباحثان أن

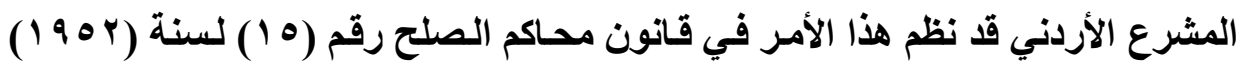
في المادة (11) منه،، (') حيث أثـارت المـادة إلى أن قرار محكمة الاستئناف في المرة

$$
\begin{aligned}
& \text { (1) حيث نصت المادة (1 (1) من قانون محاكم الصلح رقم (10) لسنة (به 19 19 على ما يلي: } \\
& \text { أفي استناف الاعاوى الصلحية الحقوقية:- }
\end{aligned}
$$

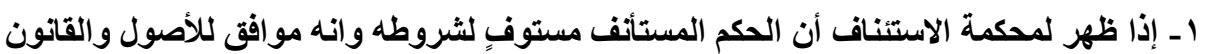

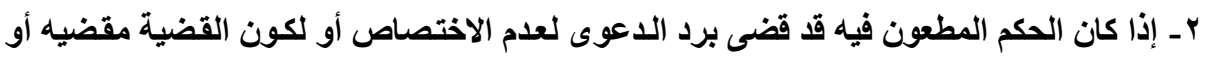

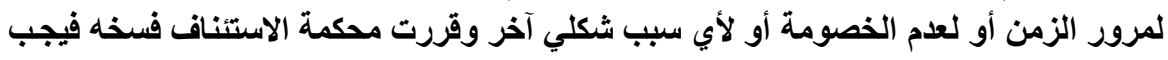

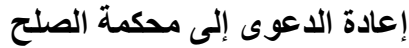

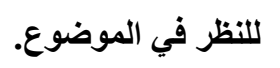

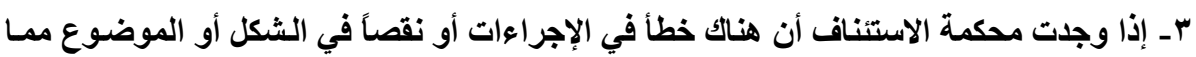

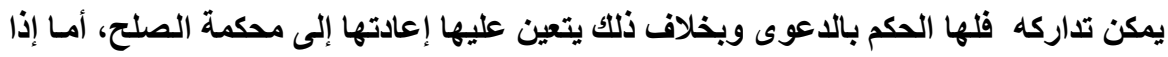

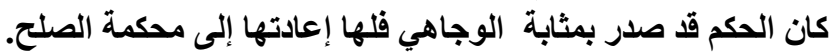

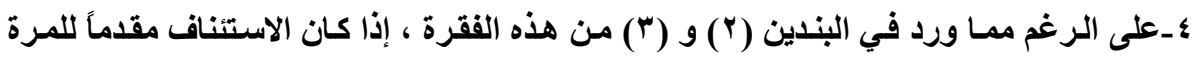

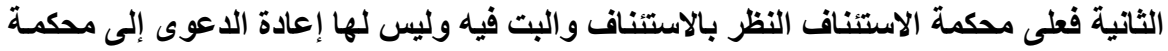

الصلح.

$$
\text { بـ في استناف الاعاوى الصلحية الجزائية:- }
$$

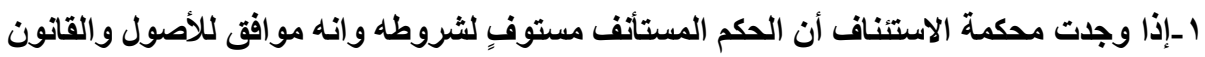

$$
\text { تفصل في الاستنناف موضوعأ. }
$$

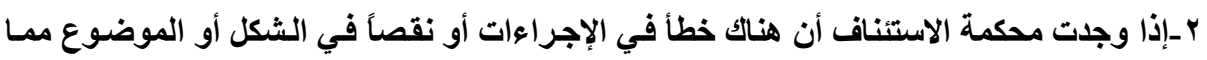

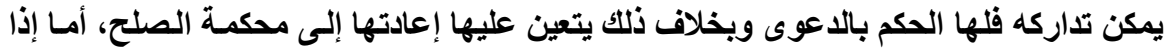

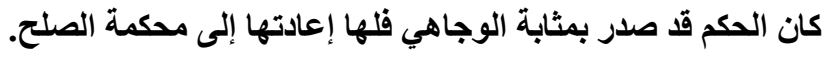

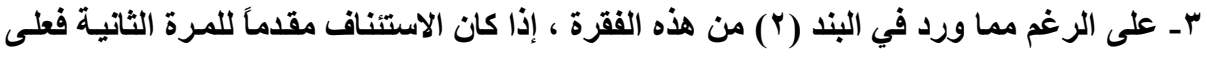

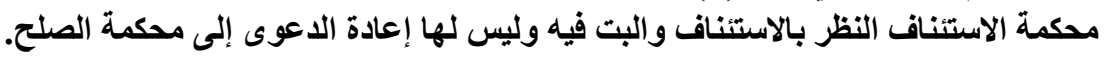
ج- لمحكمة الاستناف النظر بالدعوى مرافعة إذا وجدت ضرورة لذلكت. 
الثانيـة يكون نهائيـا ممـا يعني أن قرار الإحالـة لمحكـة التمييز يكون نهائيسا، وليس لمحكمة الاستنناف أعادة الدعوى إلى محكمة الدرجة الأولى.

\section{ثانيا: أن تكون الدعوى لا تقبل الطعن}

وفي هذه الحالة وعندما يرفض قاضي الموضوع الدفع ويقرر رفض الإحالة

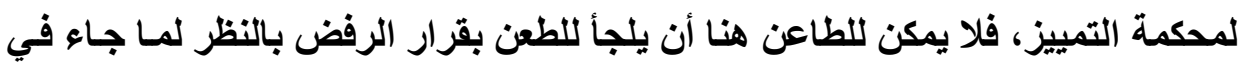

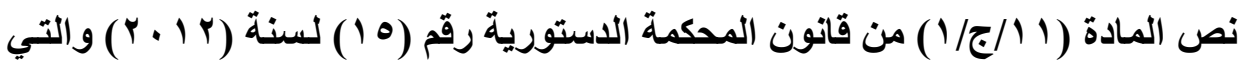

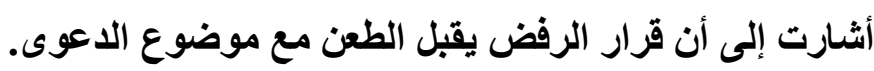

ومعنى ذلك أن قرار قاضي الموضوع بالرفض في هذه الحالة قد أصبح قطعيا، ولا يجوز للطاعن أن يطعن به بالطرق العادية، ممـا يدفعنا للتساؤل حول مدى إمكانية فية

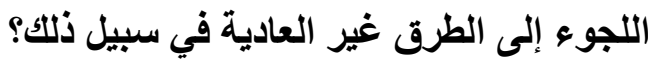

ويشار إلى أن هناك عدد من الدعاوى التي يكون قرارها قطعي ولا تقبل الطعن إطلاقا، كما هو الحـال في قضايا سلطة الأجور التي تقل قيمتها عن ( . . 1) دينـار،

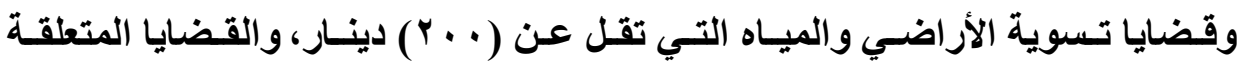

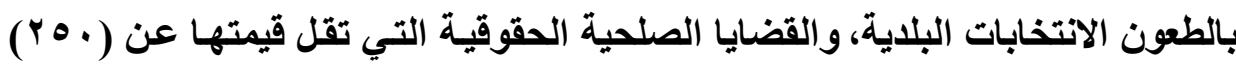
دينار، باستثناء قضايا إخلاء المأجور. وبالرجوع إلى النصوص الناظمة للطعون القضائية بالطرق غير العادية نجد أنها تتمثل بثُلاثة طرق تتمثل بطلب إعـادة المحاكمة، واعتراض الغير، والنقض بأمر خطي، والتي من المستبعد أن تنطبق على قرار الرفض الصادر من قاضي الموضوع بالنظر لثروطها المعقدة. 
كما نرى انه في حال جاز للطاعن الطعن بطريق غير عادي بقرار الرفض أن

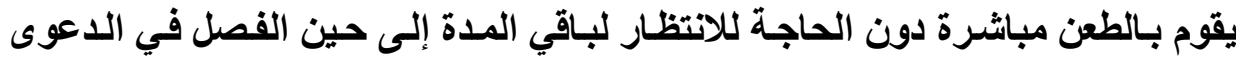
الموضوعية، وذلك لانتفاء الغاية من الانتظار بـاقي المدة، إلا أنتا نرى إمكانية تمييز

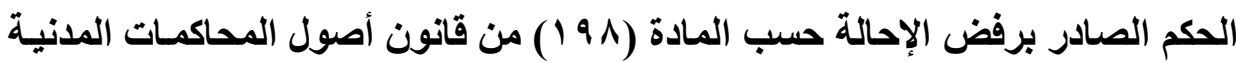
إذا ما تو افرت شروطها. ونشير في هذا الصدد إلى أن القضاء الإداري في الأردن، وعلى ضوء صدور

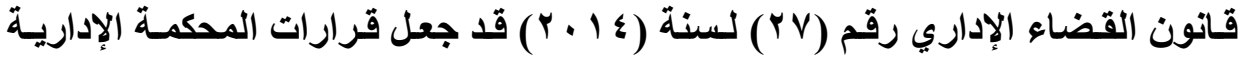
قابلة للطعن وذلك لاى المحكمة الإدارية العليا، بخلاف مـا كان سـابقا في عهد محكمة الإلـا العدل العليا والتي كانت أحكامها قطعية، ومؤدى ذلك أن قرار رفض الإحالة الصادر عن المحكمة الإداريـة قابلا للطعن لدى المحكمة الإداريـة العليا، في حين أن قرار الإحالة

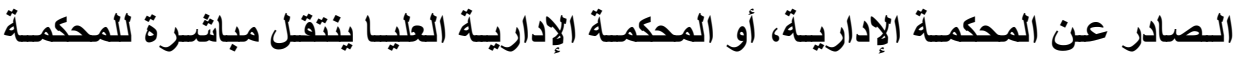
الاستورية وليس لمحكمة التمييز.

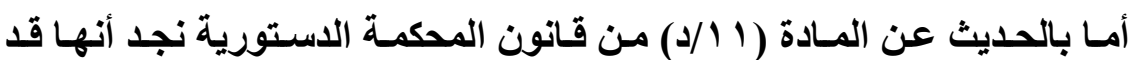
أثثارة إلى إمكانية أثارة هذا الدفع لأول مرة أمسام محكمة التمييز، والمحكمة الإداريـة، والمحكمة الإدارية العليا ومحكمة العدل العليا(سابقا)، وذلك بالنظر إلى أن هذا الطعن ذو طبيعة قانونية موضوعية، يتعلى بالنظام العام. وفي حال كاتت الأحكام غير قابلة للطعن فأن الطاعن يكون قد خسر كل طرق الطعن بعدم الاستورية في حال صدر قرار برفض الإحالة، إلا أن المشرع المصري قدابد اختصر هذا الأمر كله عذدما اغفل النص على قابلية قرار رفض الإحالة للطعن ابتداعاً، 
وهو ما يدعونا إلى التساؤل حول إمكانية الطعن في قرار الرفض بالطريق التي يطعن

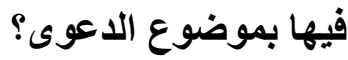

وعوداً إلى بـاقي الإجراءات فيمـا بعد صدور القرار بالإحالة يجد الباحثان أن المشرع الأردني قد أجاز لكل طرف من أطراف الدعوى أن يقلم مذكرة لمحكمة التمييز

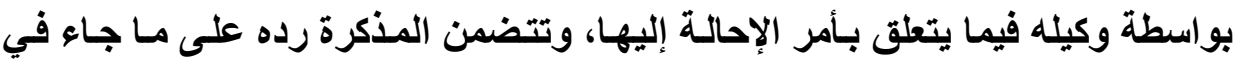
مذكرة الدفع الفرعي التي قدمها الطاعن(')، بخلاف المشرع المصري الذي أثشار إلى الـى إمكانية كل من تلقى إعلاناً بقرار إحالة، أو بدعوى، أو يودع لقلم كتاب المحكمة مذكرة

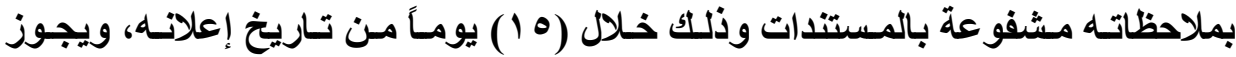
لخصمه أن يرد بمذكرة أخرى ومستتدات خلال مدة (0 10) يوم التاليـة لانتهاء المدة

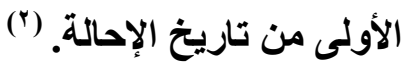

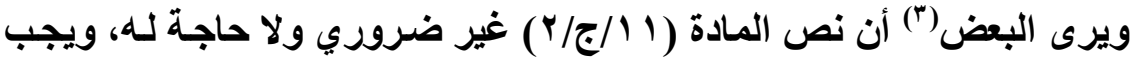
إلغاءه، إذ استتد هذا الجانب فيما ذهب إليه إلى أن أطراف الدعوى كان قد سبق لهم

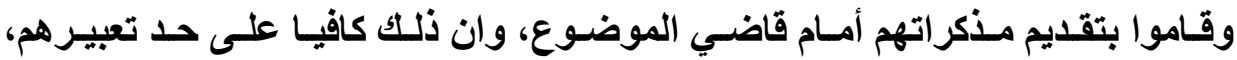
بالاضضافة إلى أنه لم يطرأ أي تطورات قانونية جديدة بعد قرار المحكمة المختصة إحالة

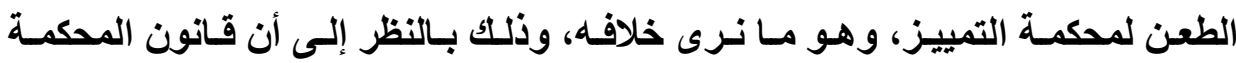
الدستورية في المادة (1 اب/) لم يلزم الأطر اف بتقديم مذكرات تتضمن ردودهم على

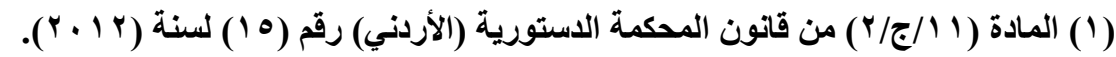

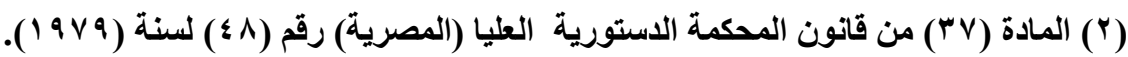

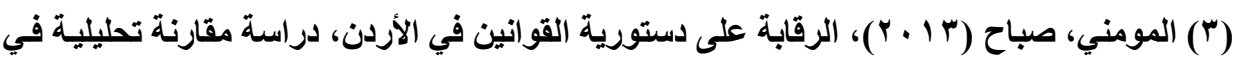

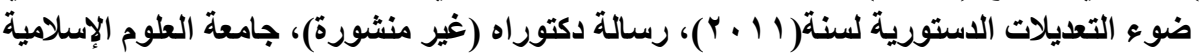

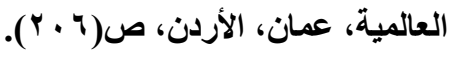


نحو ملزم، وبالتـالي يمكن أن نفترض أنهم لم يتقدموا بها خلال المرحلة الأولى أمسام قاضـي الموضوع لأي سبب من الأسباب، والأمسر الآخر الذاي مسن المكن أن نتخيله غياب احد الأطراف طوال المدة السابقة لإحالة الدعوى إلى محكمة التمييز بسبب عدام

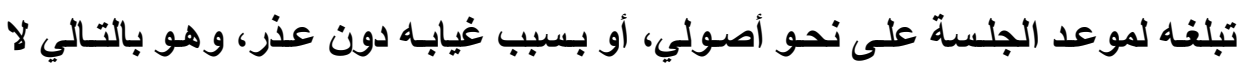
يخسر حقه في تقليم مذكرة الرد أمام محكمة التمييز، ولا أمام المحكمة الدستورية ذاتها في حال تمت الإحالة دون أن يقدمها لمحكمة التمييز، أو بسبب غيابه في الفترة السابقة كما اشرنا. ويمكن لاطراف الدعوى أن يقوموا بتقايم مذكرات الرد الخاصة بهم خلال مدة (0) يوم من تاريخ تبلغهم قرار الإحالة لمحكمة التمييز، ولا يمكنهم ذلك بعد انقضاء هذه المدة، إذ أن هذه المدة هي مدة سقوط. (1) ونحن نرى في هذا الصدد أن دور محكمة التمييز في هذه المرحلة لا يختف كثيرا عن دور محكمة الموضوع أو محكمة الاستئناف، إذ أن دور محكمة التمييز هنـا هو إعادة البحث في تو افر الجدية مرة أخرى لغايات الإحالة إلى المحكمة الدستورية من

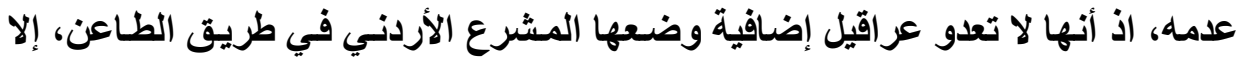
أن المشرع المـصري تجـاوز هذا النقد عندما جعل مسألة فحص الجديـة لمحكمـة

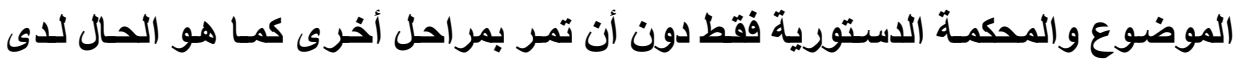

$$
\text { المشرع الأردني. }
$$

كما نرى انه لا حاجة لمثل هذا الإجراء إذ أنه تزيد لا داعي له بالنظر إلى أن أمر الجدية قد تم بحثه مسبقا من قبل قاضي الموضوع، ممـا يجعل من مسالة إعادة بحثّه

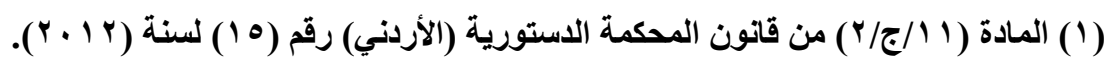


مـن قبل محكمـة التمييز مجرد مماطلة مـن قبل المشرع، و إضـافة عقبـات في وجـه الطاعن، ليس هذا فحسب، إذ أن المحكمة الدستورية سوف تقوم في نهاية المطاف بإعادة فصص مدى الجدية في الدفع مرة أخرى، ولا تعتد بمـا كاتت محكمة الموضوع، أو محكمة التمييز القيام به من فحص لجدية الافع. وتجتمع لهذه الغاية محكمة التمييز بهيئة مكونة من ثلاثة أعضاء على الأقل،

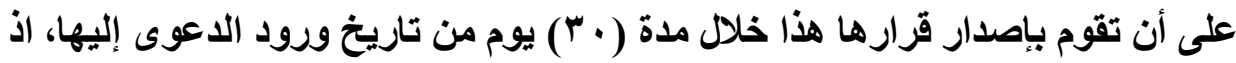
نرى أن هذه المدة تنظيمية، كما لا يترتب على تجاوزها أي جزاء، و إنما وضعت لغايات السرعة في البت في الدعاوى المحالة إليها من محكمة الموضوع. كما أن محكمة التمييز في هذه الحالة ليس لها إلا أن تقوم بأحد أمرين حيال الدعوى المحالة إليها من محكمة الموضوع: الأهر الأول: الموافقة على الإحالة، وفي هذه الحال تقوم بتبليغ أطراف الدعوى بذلك.

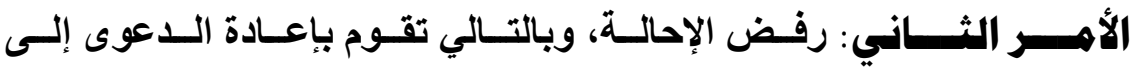
محكمة الموضوع للسير في إجراءات اللدوى الموضوعية من النقطة التـي انتهت إليها. ومن ناحية أخرى نرى انه في حال رفض محكمة التمييز، أو المحكمة الإداريـة العليا إحالة الدعوى إلى المحكمة الدستورية فانه يغلق باب الطعن أمام الطاعن، وليس

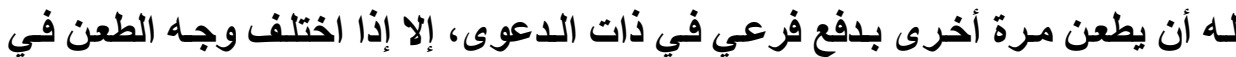

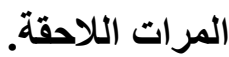


وفي ذلك تأكيد على حجية الأحكام الدستورية الصادرة عن المحكمة الدستورية، وهو ما أكده جاتب من الفقه (') والذي نتفق معه في ذلكت.

كمـا أن لكل مـن أطراف الدعوى أن يقدم مذكرة إلى المحكمـة الاستورية بعد إحالكة الدعوى إليها من قبل محكمة التمييز، ويعرض فيها بصورة واضحة ومحددة إندان القانون أو النظام الذي أثثير الدفع بعدم دستوريته، ونطاق هذا الدفع ووجها مخالفة الاستور على النحو الذي سبق بيانه خلال خمسة عشر يومـاً من تاريخ تبلغه قرار

الإحالة إلى المحكمة الاستورية.

كما أن هذه المدة هي مدة سقوط لحق الدافع بعدم الدستورية، وفي حال فوت هذه المدة دون أن يقدم مذكرته على النحو المشار إليه فلن يستطيع أن يقدمها مرة أخرى على الإطلاق في أي وقت أخر بعد مضي مدة (10) يوماً على تبلغه قرار الإحالة. وللاطراف الآخرين في الدعوى أن يقدموا مذكرات تتضمن ردهم على المذكرة

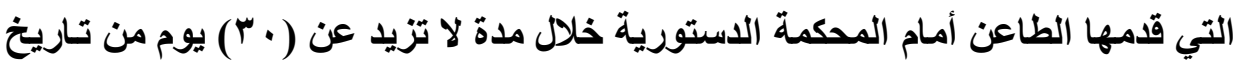
تبلغهم قرار الإحالة، وللمحكمة أن تقرر الاكتفاء بما تم تقديمه من مذكرات. كما يقوم المكتب الفني بأمر من رئيس المحكمة الاستورية بإرسال نسخة من كل قرار إحالة وصل إلى المحكمة الاستورية عن طريق تطبيق نص المـادة (1 (1) من

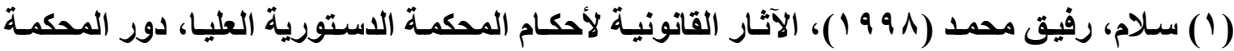

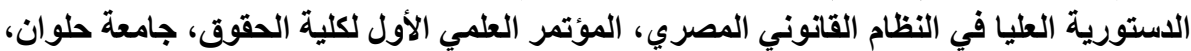

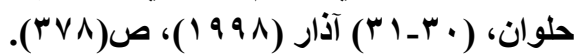

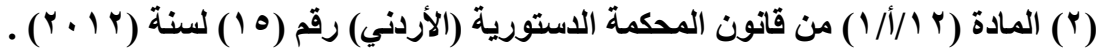

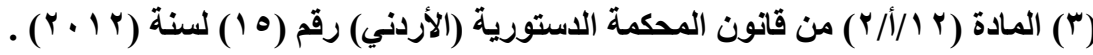


قانون المحكمة الدستورية الأردنية(')، واستلام الرد عليها من رئيس مجلس الأعيان،

$$
\text { ورئيس مجلس النواب، ورئيس الوزراء. () }
$$

ويتوجب على هذه الجهات أن تقدم ردها على هذا الطعن خلال مدة (· ( ) أيام

من تاريخ تسلمه، وهو أمر يدعو للتعجب من هذه الإجراءات المعقدة التي تطلبها المشرع الأردني، والتي جعها طويلة جدا، إذ أن مجرد التفكير بسلوك هذا الطريق كاف لهن

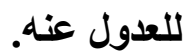

ونرى أن المشرع هنا قد تطلب رد مجلس الأعيان، والنواب خلال عشرة أيام، فهل يغني ذلك أن تقوم المحكمة الاستورية بانتظار مجلس الأمة للانعقاد مرة أخرى في دورته العادية، أو غير العادية حتى يتم إعمال هذا النص؟ وبالنظر إلى أن مجلس الأمسة

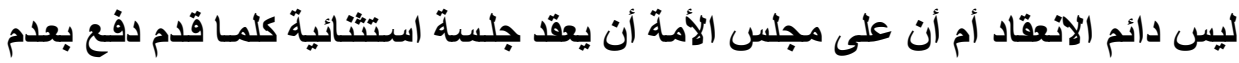
الدستورية من احد الأفراد؟! وهو أمر غير منطقي على الإطلاق، أو أن يتم الاستغناء عن المذكرات التي تتعلق بكل من مجلس الأعيان، ومجلس النواب في فترة علدم الانعقاد بالنظر إلى عدم إلزامية تقديمها ابتاءأ والاكتفاء بما يقدمه رئيس الوزراء حول ذلك! كمـا نلاحظ أن المشرع الدستوري الأردنسي في المسادة (1/0^) أنشسار إلى أن المحكمة الاستورية هيئة قضائية مستقلة قائمة بذاتها، وهو مـا نجد خلافه في ثنايا القانون، إذ أن على المحكمة أن تنتظر آراء مجلس الأعيان والنواب، بالإضافة إلى رأي

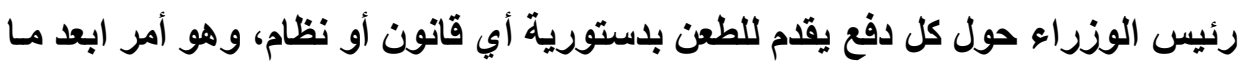
يكون عن الاستقلالية التي أثدارت إليها المادة (1/0^) من الاستور الأردني. 
ونحن نرى أن إقحام السلطة التنفيذية، والسلطة التشريعية، في صميم عمل

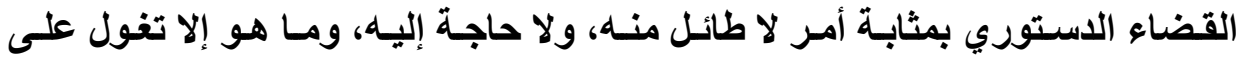
صلاحيات المحكمة وانتهاكاً لاستقلاليتها التي أثشارت إليه المـادة (1/0^) من الاستور الأردنـي، كمـا أنتـا نتساعل حول القيمة القانونيـة للمذكرات التي تقوم بتقديمها هذه الجهات المشار إليها في المسادة (ץ //ب) من قانون المحكمة الدستورية، ومـا مدىى إلزامها للمحكمة الدستورية؟ إذ أن ما نراه في هذا الصدد هو أنها غير ملزمسة للمحكمة الئا بالنظر إلى أن تقيم هذه المذكرات غير إلزامي ابتداءاً. كما وقد أثشارة المادة (r /ج) من قانون المحكمة الاستورية أن على المحكمة أن تفصل بالطعن المحال إليها من المحاكم خلال مدة (· r I ) يوم، ونلاحظ أن هذه المدة هي ذاتها المدة التي أشارت إليها المـادة (• //ب) من قانون المحكمة الدستورية رقم

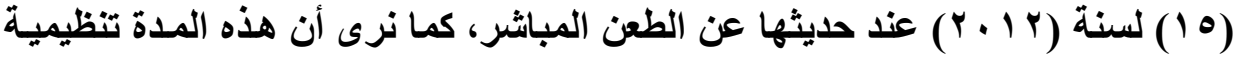
أيضا، لما لهذه الطعون من خصوصية نتيجة ارتباطها بالاستور، ولسرعة البت فيها، وكما اشرنا سابقا فلا يترتب على مخالفة هذه المدة أي جزاء لكونها مدة تنظيمية، ولا

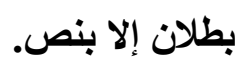

كما ان للمكمة الاستورية الحصول على أي معلومة ترى أنها ضرورية للفصل في الطعون المقدمة إليها على النحو الذي تراه مناسبا، وذلكت من خلال المراسلات الرسمية والاستثارات المتخصصة لأي جهة من الجهات ذات الارتباط. (') ونلاحظظ أن المشرع قــ جعل مـن قـانون المحكمة الدستورية مستنقعاً مليئـا بالعقبات، ليس من الناحية الإجرائية فقط، بل ومن الناحية المادية أيضا، وذلك بالنظر

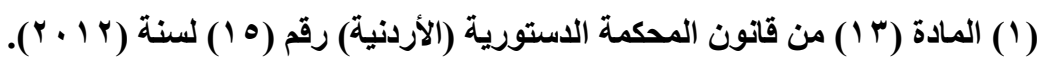




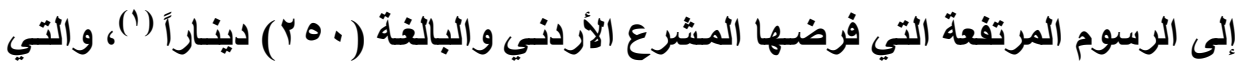

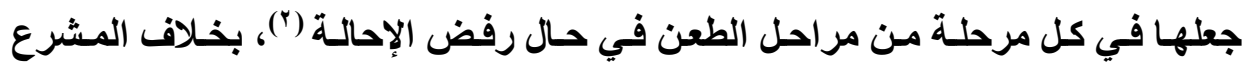

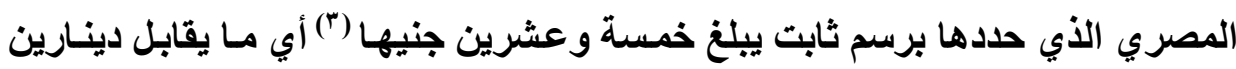

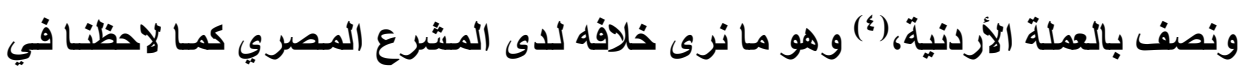
المادة (9 ץ) من قانون المحكمة الاستورية العليا.

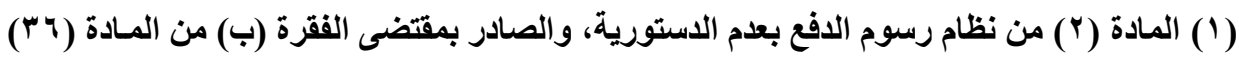

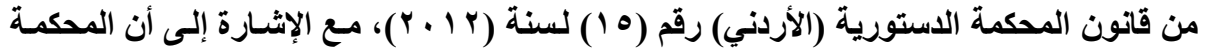

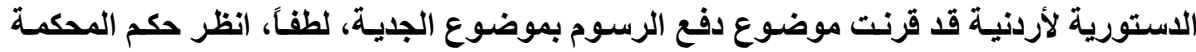

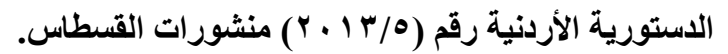

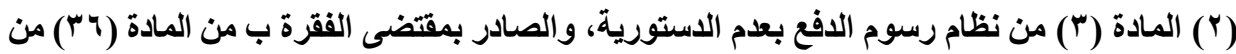

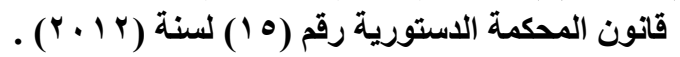

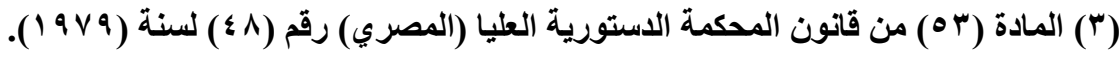

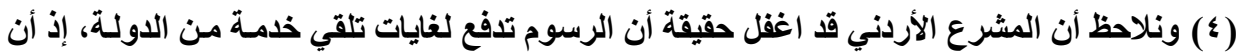

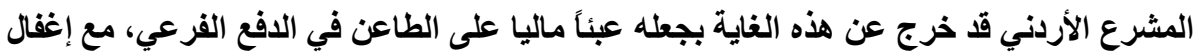

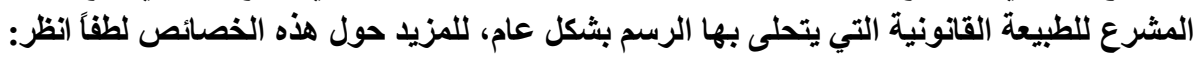

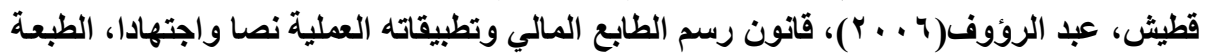

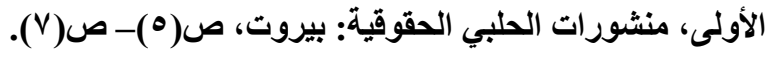




\section{المبحث الثالث \\ المكم الصادر في الدعوى الدستورية}

يمر الحكم أو القرار الصادر عن المحكمة الاستورية بعدة مراحل في اللاعوى

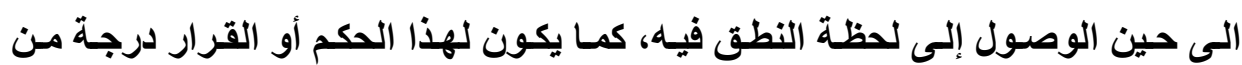
الحجية تختلف عن حجية مـا سواه من أحكام وقرار المحاكم الهيئات الأخرى داخل

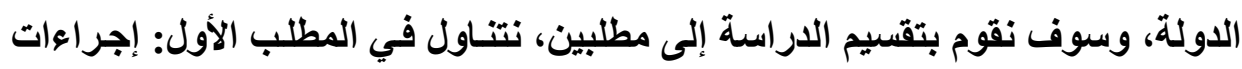
إصدار الأحكام في المحكـة الاستـورية، وفي المطلب الثـاني: مـدى حجيـة الأحكام الصادرة عن المحكمة الاستورية.

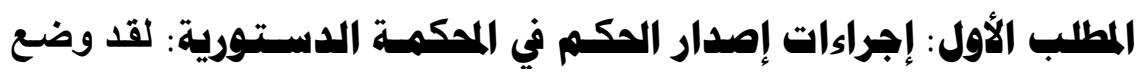

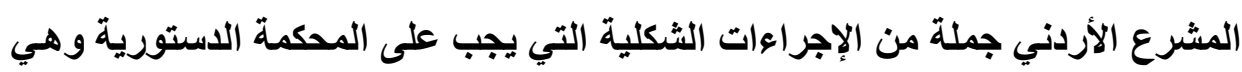
بصدد إصدار أحكامها أن تلتزم بحدودها، وألا فـأن قرارهـا يعتبر معيبـا مـن الناحيـة

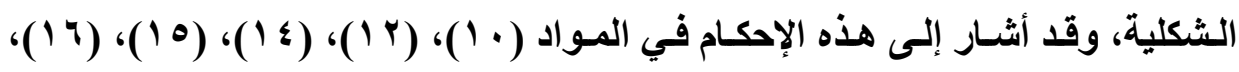
(7) 19)، (19 (19) من قانون المحكمة الاستورية. كما أن المشرع الأردنسي قد اشترط مجموعة من الشروط على المحكمة حتى

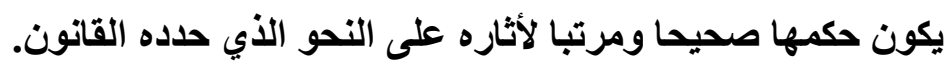
فقد أشـارت المـادة ( • ا/ب) من قانون المحكمة الاستورية إلى المدة اللازمـة للفصل في الطعون الناتجة عن الدعاوى المباشرة للمحكة والتي جاء فيها: 
"تفصل المحكمة في الطعن خلال مدة لا تتجاوز مائـة وعشرين يومـاً من تـاريخ

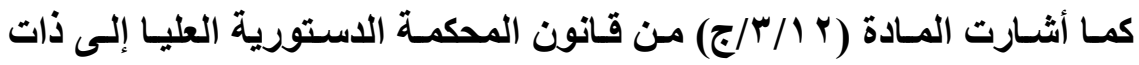
الأمر بالنسبة للطعون المحالة للمحكمة الاستورية من المحاكم الأخرى حيث جاء فيها: "تفصل المحكمة في الطعن المحال إليها من الححاكم خـلال مــدة لا تتجاوز مائة وعشرين يوماً من تاريخ ورود قرار الإحالة إليها".

وينـاءا على مـا تقدم فأن للأحكام الصادرة عن المحكمة الاستورية جملة من

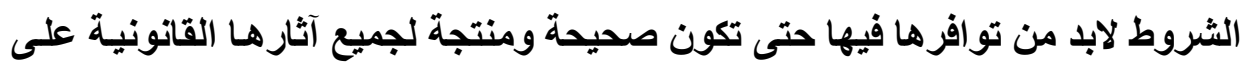
النحو الذي بينه الاستور، والتي سوف نستعرضها من خلال الفروع الأربعة التالية: الفـرع الأول: شـرط المسدة: أن الشرط الأول مـن شروط الحكم الصادر عن

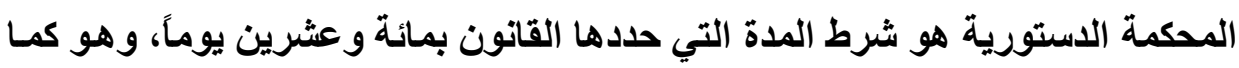
نرى انه لا يعدو كونه سوى شرط تنظيمي، وهي المدة اللازمة للفصل في الطعن في

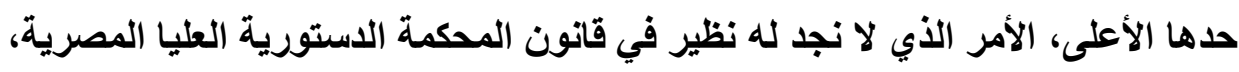

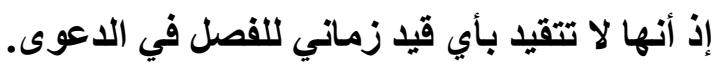

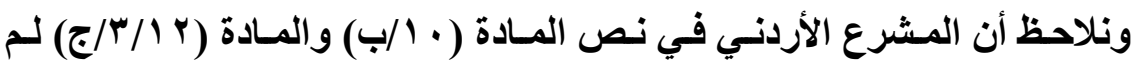
يبين فيما إذا كان بالإمكان تمديد هذه المدة لفترة أطول في حال من الأحول، سواء كلان ذللك لظرف طارئ أم لأي داع آخر. كما نلاحظ أن المشرع الأردني لم يبين الجزاء على مخالفة أحكام هذا الشرط

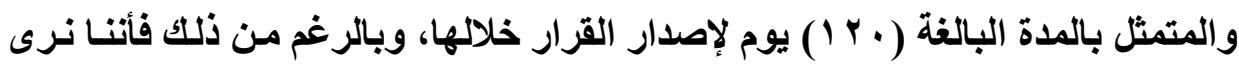


أن هذه المدة هي في حقيقة الأمر مدة تنظيمية، لغايات إجبار المحكمة على السرعة في

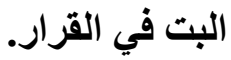

ونـرى أن المشرع الأردنـي لـم يكن موفقـا وهـو بـصدد سـن قـانون المحكمـة

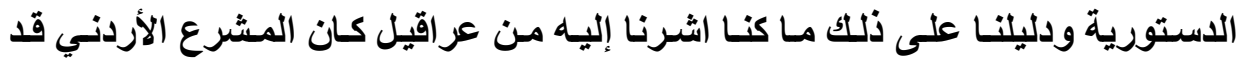
وضعها في طريق الطاعن، سواء كانت عراقيل إجرائية شكلية، أم عراقيل ماديـة، أو

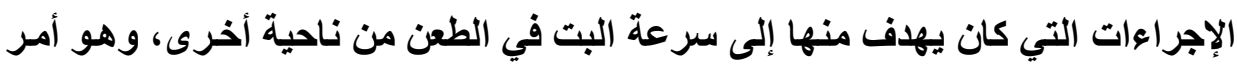

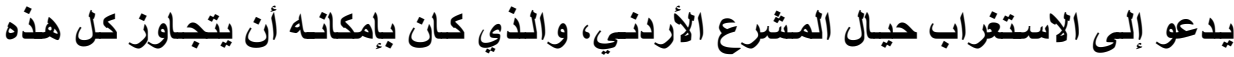

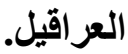

ومن الأمثلة على هذه العراقيل ما هو عليه الحال من انتقال ملف اللاعوى من محكمة إلى أخرى، وإجراءات التبليغ الطويلة، وتبادل المذكرات والردود حول الطعون المقدمة، وفحص مدى الجديـة مرارا وتكرارهـا على نحو لا يعدو كونـه إهدارا لوقت إلت المحكمة، واستنزاف لجها الطاعن، وأضعافا لعزيمته من المضي قدما في طعنه، إلى الى

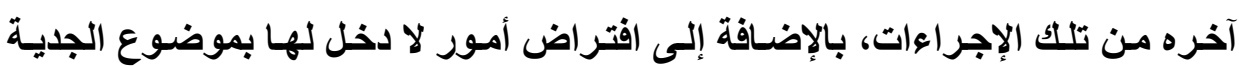
والذي نرى انه من قبيل المسائل الموضوعية التي يبحث فيها القاضي ويقرر ماهيتها ودلانلها في حين أن المحكمة الدستورية الأردنية قد اعتبرت مسألة دفع الرسوم (وهو أجراء شكلي) من قبيل قرينة الجدية في الدفع، (') ونجد أن المشرع الأردني في نهاية المطاف وإبرازا منه لحسن النية من قبله قد وضع لنـا في قانون المحكمة الاستورية

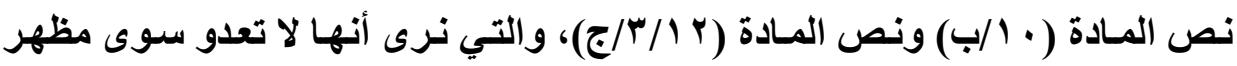


زائف يخفي ورائه العديد من العقبات التي كان المشرع قد رسمها منعا من الوصول إلى المحكمة الاستورية، وحتى لا يتم الطعن بعدم دستورية أي قانون، أو نظام. ويؤكد ما ذهبنا إليه ما قام به المشرع من حرمان للمحكمة الاستورية من ابسط حقوقها وهو حق الطعن من تلقاء نفسها، أو على الأقل حق التصدي كالذي جاء بـه المشرع المصري. (') ونلاحظ أن المشرع المصري قد مهذ الطريق أمسام الطاعن ولم يضع أي قيد أو

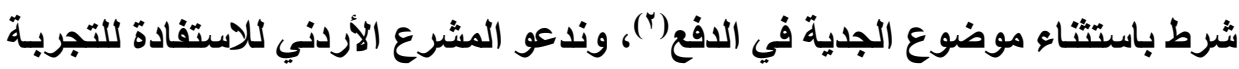
المصرية في هذا الخصوص، وإزالة كافة العراقيل من طريق الطاعن. كما وقد نصت المادة (ع ا ) من قانون المحكمة الاستورية الأردنية على ما يلي: "تصدر المحكمة أحكامها مسببة بشأن الطعون المقدمة لايها وفق أحكام هذا القانون تدقيقًا أو في جلسة علنية وفق ما تراه مناسباً". الفرع الثاني: شرط التسبيب: هو بأن تورد الدحكمة الدوافع التي أدت بها

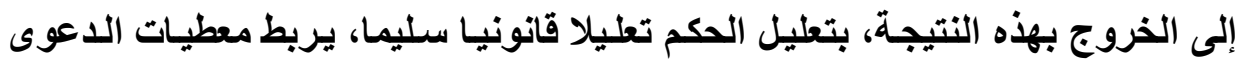
بالنتيجة التي توصلت إليها المحكمة في حكمها.

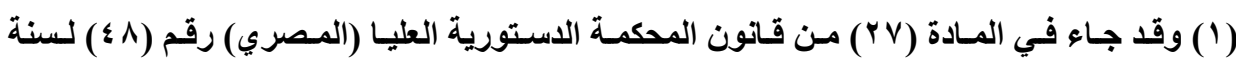

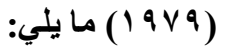

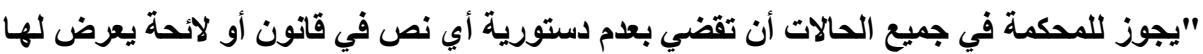

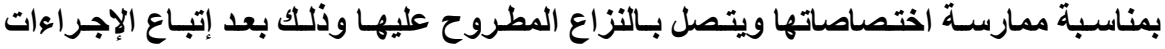
المقررة لتحضير الاعاوى الاستورية".

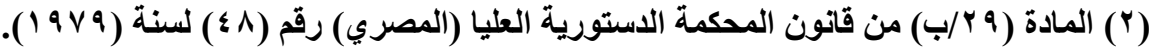


ويعتبر التسبيب من الشروط الشكلية التي يجب على المحكمة أن تراعيها في كافة الأحكام الصادرة عنها، ولا يجوز تجاهلها أبدا، وإلا كـان الحكم بـاطلا لمخالفتهـ الشكل الأي حدده القانون لحكم المحكمة. إلا أن قانون المحكمة الاستورية العليـا قد خلا من الإشـارة إلى تسبيب الحكم الصادر عن المحكمة، الا انتـانـرى ضـرورة أن يكون القرار مسببا، وهو مـا أثثبتـهـ المحكمة الاستورية العليا بالتطبيق العملي، إذ أن جميع الأحكام الصادرة عنها مسببة على نحو وافي. (') كما يمكن للمحكمة الاستورية أن تصدر أحكامها تدقيقا أو بجلسة علنية، ومعنى ذلكك أن للمحكمة أن تقوم بلراسـة الحكم وإصداره دون حاجة لحضور أطراف الطعن ومثولهم أمام المحكمة. (r) الفرع الثالث: شرط أن يصدر المكم باسم جلالة الملك: فقد أثشارت المسادة (10/أ) من قانون المكمة الدستورية إلى ضرورة أن يكون الحكم أو القرار صـادرا

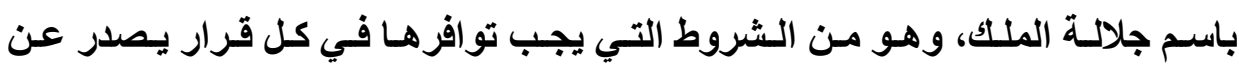

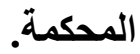

وبالإثـارة إلى بعض مـا جـاء حول هذا الأمر وفق اجتهادات محكمة التمييز

الموقرة والتي أثشارت في بعض قراراتها إلى أن الحكم يكفي أن يكون قد صدر باسم

(1) حيث جاعت جميع أحكام المحكمة الدستورية العليا (المصرية) مسبية ومعللة تعليلا وافيا على نحو الطعا

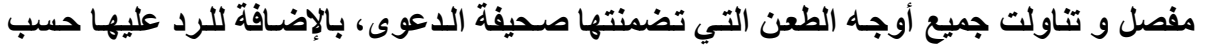

الأصول والقانون، لطفا راجع أية قرار حكم صادر عن المحكمة الدستورية العليا.

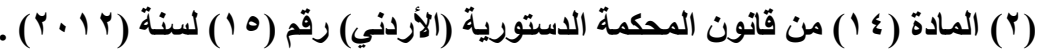


صاحب الجلالة في ديباجته دون إلزامية ذكر ذلك في تذييل الحكم، حيث جاء في احد

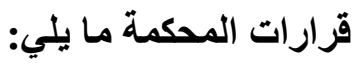

"... وعن اللبب الثامن والذي ينصب على أن القرار المميز مخالف للقانون

ونص المسادة (YV) من الدستور الأردني حيث لم يصدر باسم صـاحب الجلالة الملك المعظم، وبالرجوع إلى القرار المميز نجد انه تضمن في ديباجته أن الحكم صدر باسم حضرة صاحب الجلالة ملك المملكة الأردنية الهاشمية عبد الله بن الحسين المعظم،

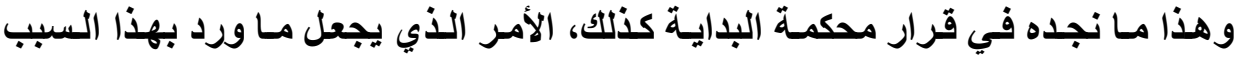
مخالف لواقع الحال، ومستوجب الالتفات عنه ورده". (') وبالقياس على حكم المادة (YV) من الدستور فأن ذات النتيجة تترتب في حال مخالفة نص المادة (1/09) من الاستور وهي البطلان، وبالتالي فأن الحكم لا يرتب أي

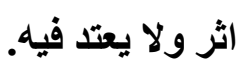

ويشار إلى أن محكمة التمييز لم تثترط أن يكون الحكم مذيلا باسم جلادة الملك بل يكفي أن يكون الحكم مروساً باسم جلالته. إلا أن قانون المحكمة الاستورية العليا المصرية قد اشترط أن يكون الحكم باسم 


\section{الفرع الرابـع: شـرط صحة التشكيل القضائي للمشكمة عنس إصـدار}

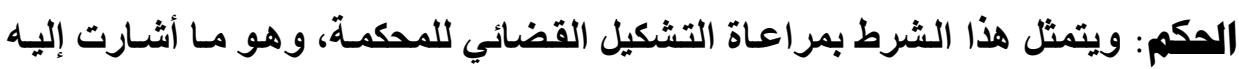
المادة (9 1) من قانون المحكمة الاستورية والتي جاء فيها ما يلي:

"تنعقد المحكمة عند النظر في الطعن أو طلب التفسير المقدم لديها بهيئة

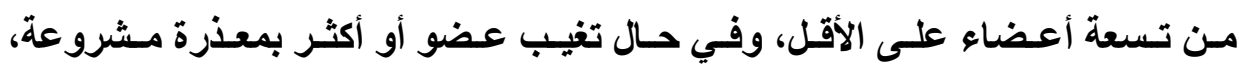
أو تحققت إحدى حـالات التتحي، تنعقد بحضور سبعة من أعضائها على أن يكون

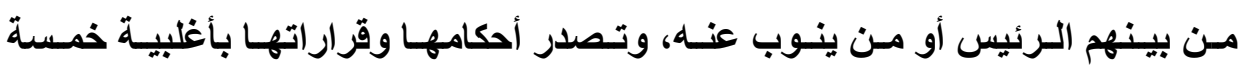

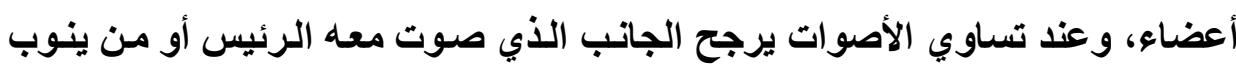

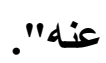

و هـو مـا أكلدت عليهه المسادة (9) مسن تعليمسات إجراءات الفصل في الطعون

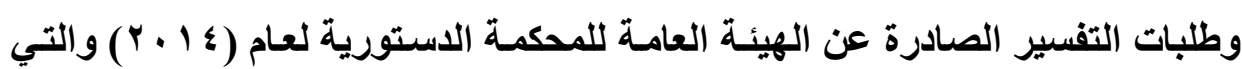
جاء فيها: "تصدر المحكمة أحكامها بالطعون وقراراتها بطلبـات التفسير وفق الأكثريـة

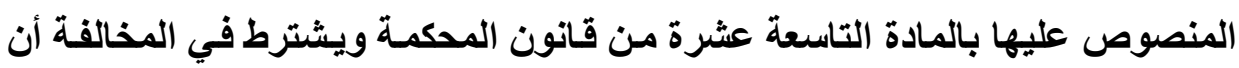

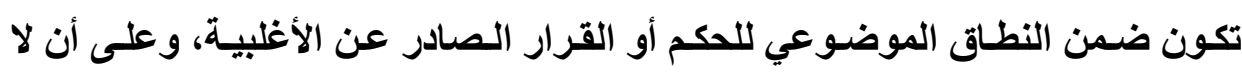
يتجاوز نقطة أو نقاط الاختلاف معها". فيتوجب على المحكمة الدستورية أن تصدر أحكامها في الطعون الاستورية أو

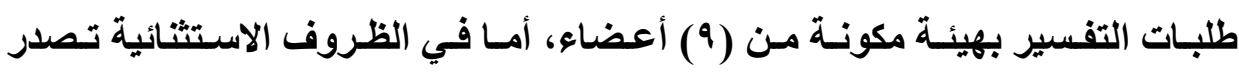
أحكامها من هيئة مكونه من (V) أعضاء في حالات التنحي أو الغياب بعذر. 
وقد تناول جانب من الفقه الأثر المترتب على صدور الحكم القضائي من عدد اقل من العدد الذي تطلبه المشرع لألك وقد رتب على ذلك عدة نتائج تباينت بين الانعدام

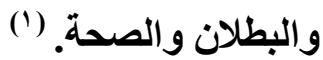
ونرى أن هناك عنصر أضافي يتعلق بهذا الثرط يتمثل بحضور الأعضاء الذين اشتركوا في المداولة قبل إصدار الحكم، ووقعوا على مسودة الحكم في مرحلة المداولة، إذ لا يجوز أن يشترك في إصدار الحكم من لم يشارك في المداولات قبل إصداره. وقد أثدارت المادة (1/1) من قانون المحكمة الدستورية على ما يلي: "تكون مداولات المحكمة سرية". ويترتب على هذه المادة أن مسودة الحكم تعتبر سرية أيضا، ولا يجوز الاطلاع عليها من قبل الأطراف قبل صدور الحكم، ولا يجوز نشرها أو نشر أي جزء منها قبل ذللك على الإطلاق. وبخلاف ذلك تكون الأحكام الصادرة عنها باطلة لمخالفتها الشرط الشكلي الذي

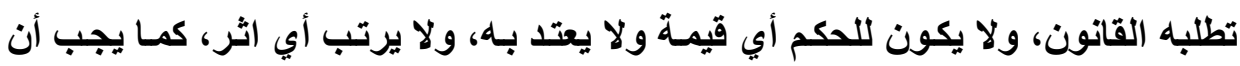
يصدر حكم المحكمة بأغلبية (0) أعضاء حتى يصدر القرار، وفي حال تساوي الأصوات يرجح الجانب الذي صوت معه الرئيس. 
أما المشرع المصري فقد اشترط لصحة تشكيل المحكمة أن تتعقد المحكمة من سبعة أعضاء، ولا يجوز أن يقل عدد الأعضاء عن هذا الحد وألا كان الحكم بـاطلا، (')

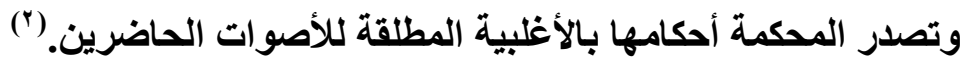
وقد أشارة الاستور الأردني إلى الإجراء الختامي في عملية إصدار الأحكام عن

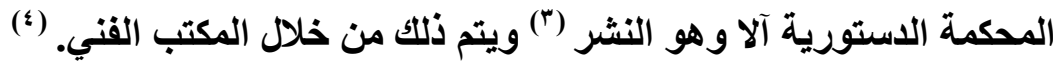
وقد جاء في عجز المادة (1/89) من الاستور الأردني ما يلي: "... وتنثر أحكام المحكمة الاستورية في الجريدة الرسمية خلال خمسة عشر

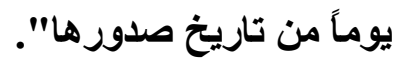

أما المادة (1 1 ) من قانون المحكمة الاستورية فقد أكلت على هذا الإجراء حيث

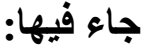
"أـ ترسل المحكمة نسخاً من الأحكام الصادرة عنها فور صدورها إلى كل من: ا-روؤساء الجهات المحدةة في الفقرة (أ) من المادة (9) من هذا القانون.

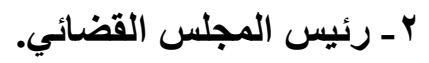

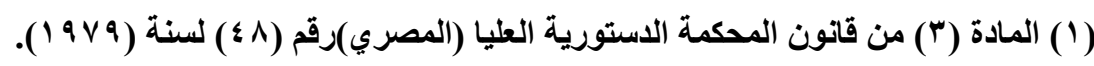

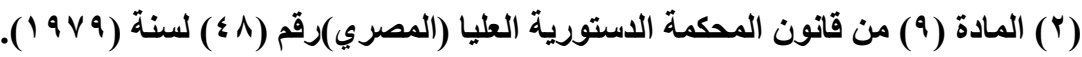

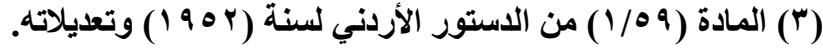

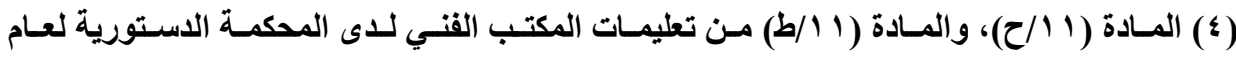
$(r \cdot 1 r)$ 
بـ تنشر أحكام المحكمة في الجريدة الرسمية خلال خمسة عشر يومـاً من تاريخ

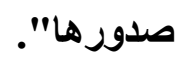

ويناءا على ذلك يتوجب على المحكمة بعد أن يصدر حكمها أن تقوم من خلال

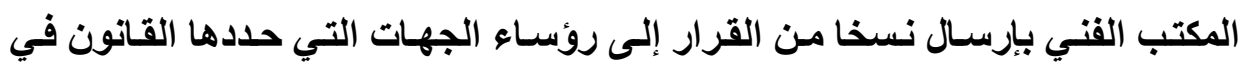
المسادة (9/أ) (من لهم حق الطعن بدعوى مباشرة)، بالإضـافة إلى رئيس المجلس

ونرى أن هذا الإجراء الذي أشسارت إليهه المـادة (9/09) من الاستور والمسادة

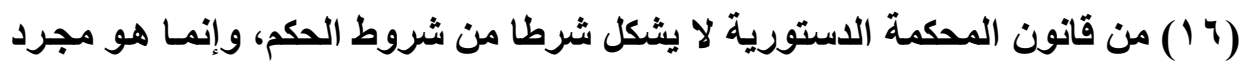
إجراء لاحق على صدوره لغايات إثهاره لاى الجهات ذات العلاقة، وللكافة. كمـا نـرى هنـا أن القـانون عندما أضساف هذا الإجراء بعدا إصدار الحكم مـن

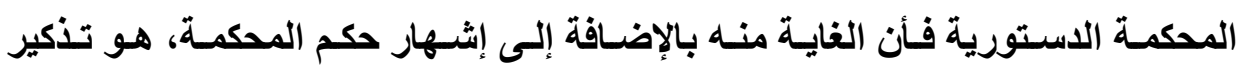

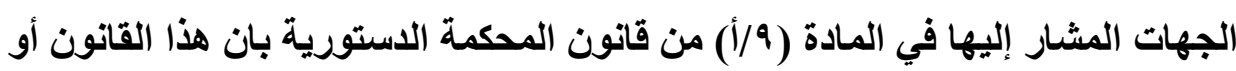

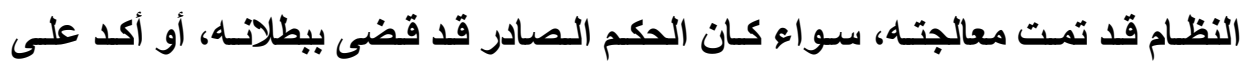

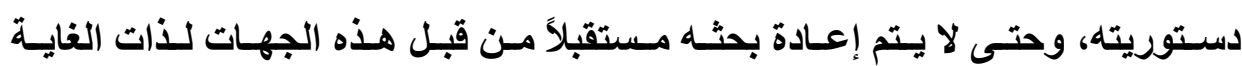

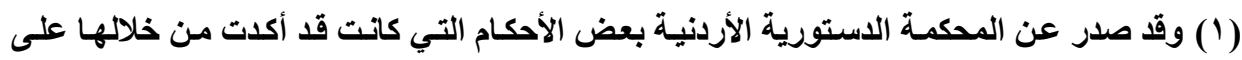

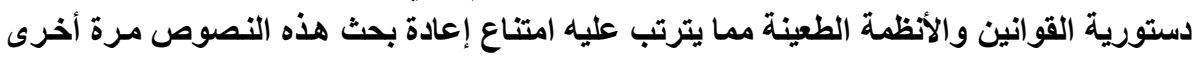

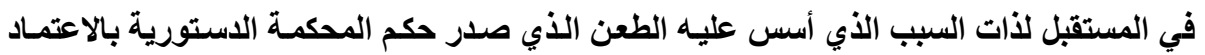

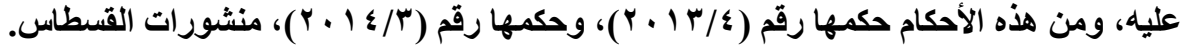


كما يتوجب على المحكمة نثر الحكم في الجريدة الرسمية بعد مدة (ه 1) يوم على صدوره في الجريدة الرسمية، وهو لغايات إشهار الحكم لاى العامة. كما أن المشرع المصري قد اشترط ذات الأمر عندما نص في المـادة (9 ؛ ) من قانون المحكمة الاستورية العليا إذ نص القانون على ما يلي: ".... وتنشر الأحكام والقرارات المشار إليها في الققرة السابقة في الجريدة الرسمية، وبغير مصروفات خلال خمسة عشر يوماً على الأكثر من تاريخ صدور ها...". ومن ناحية أخرى نرى أن المشرع الأردني قد أضاف جهة أخرى تتمثل برئيس المجلس القضائي للفئات التي يتوجب على المحكمة تزويدها بنسخة من حكم المحكمة، اذ نرى أن الهدف من هذا الإجراء هو ان يتم تعميم الحكم على المحاكم، ودوائر الادعاء العام، ودوائر النيابة العامة داخل المملكة؛ حتى لا يتم تطبيق النص المخـالف للاستور

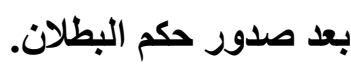

\section{المالسب الثـاني: عبيسة الأحكسام والقـرارات الـصادرة عـن المكمهـة} الدســتورية، ونفاذهــا: اذ لا بـ للحكم القضائي أيـا كـان مـصدره بعد أن يستوفي إجراءاته الشكلية أن يصبح ناقذا، وله من القوة والحجيـة مـا نص عليه القـانون طالمـا صدر صحيحا مستوفيا لشروط إصداره. ولذلك فأن الحكم الصادر عن المحكمة الاستورية وبعد أن يكون قد استوفى الثروط الثكلية التي اشرنـا أليها أعلاه لا بل له من أن يصبح نافذا، وله من الحجية مـا يمكنه من تأدية الغاية منه وهي إبطال القوانين والأنظمـة المخالفـة للاستور، أو تقرير دستورية هذه النصوص، أو إزالة الغموض الذي كان يكتنف نصوص الاستور. 


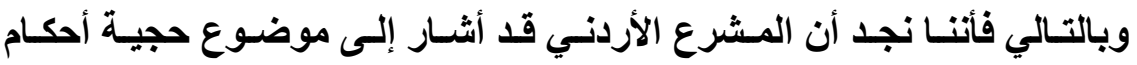

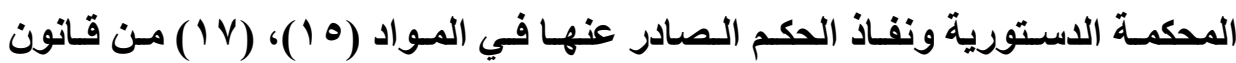

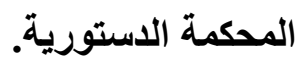

وقد جاء في نص المادة (0 10) من قانون المحكمة الدستورية ما يلي: "أـ تصدر المحكمة حكمها في الطعن المقدم لايها باسم الملتك، ويكون الحكم الصادر عنها نهائياً وملزماً لجميع السلطات، و الكافة. بـ مع مراعاة أحكام الفقرة (ج) من هذه المـادة يكون الحكم الصادر عن المحكمة نافذاً بأثر مباشر ما لم يحدد الحكم تاريخاً آخر لنفاذه، فإذا قضى بعدم دستورية قانون أو نظام نافن يعتبر القانون أو النظام باطلاً من تاريخ صدور الحكم، وإذا حدد الحكم تاريخاً آخر لنفاذه فيعتبر القانون أو النظام باطلاً من التاريخ المحدد

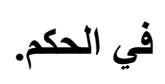

ج- إذا قضت المحكمة بعدم دستورية نص يفرض عقوبة فيوقف تنفيذ الأحكام التي قضت بالإدانة استناداً لذلك النص وتتنهي أثثار ها الجزائية. دـ إذا قضت المحكمة بعدم دستورية أكثر من نص في القانون أو النظام فللمحمـة التفريق في تاريخ نفاذ حكمها بين نص و آخر وفق ما تراه مناسباً". في حين أن المشرع المصري قد أثـار إلى مسألة الحجية في المسادة (^؟) والمادة (9 ؛ ) من قانون المحكمة الاستورية العليا. 
وبالاستناد إلى كل ما تقدم سوف نقوم بتقسيم الاراسة إلى فرعين نتناول في الفرع الأول: نفاذ أحكام المحكمة الاستورية، أما في الفرع الثاني: حجية هذه الأحكام،

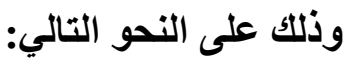

الفرع الأول: نفاذ أحكام المكمة الدستورية: انهه وبالرجوع إلى النصوص

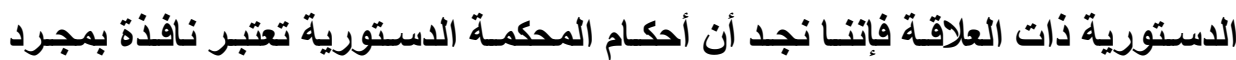
صدورها عن المحكمة بأثر مباشر وفوري، وذلك بالاستناد إلى نص المـادة (9 ه) من الاستور الأردني والتي جاء فيها:

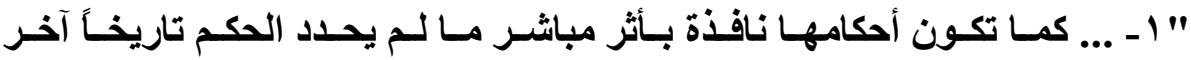

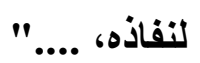

ץـ للمحكمـة الدستورية حقى تفسير نصوص الاستور ....، ويكون قرارهـا نافــ

$$
\text { المفعول بعد نثره في الجريدة الرسمية". }
$$

في حين أن المشرع المصري في قانون المحكمة الدستورية قد ذهب خلاف ذلك

$$
\text { إذ جاء في نص المادة (9 ؛ ) من القانون ما يلي: }
$$

"ويترتب على الحكم بعدم دستورية نص في قانون أو لائحة عدم جواز تطبيقه

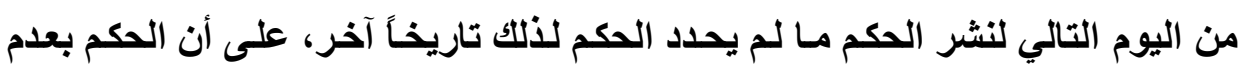
دستورية نص ضريبي لا يكون لـه في جميع الأحوال إلا مباشر، وذلكك دون إخلال

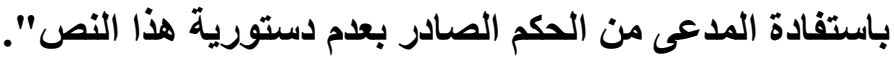
وبناءا على ذلك فأن لحظة النفاذ لاى المشرع الأردني تبدأ منذ صدور الحكم، ما

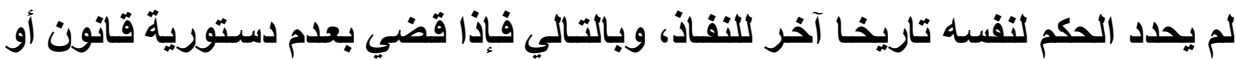
نظام معين فأنه يعتبر باطلا من تاريخ صدور الحكم بذلك، كمـا أن للحكم أن يبين تثاريخ 
آخر لنفاذه، وبالتالي يبطل القانون أو النظام الذي قضي بعدم دستوريته منذ ذلك التاريخ تحديداً، وقد يكون تاريخا سابق أو لاحق لتاريخ إصدار الحكم. كما نرى أن نص المادة (1/09) من الاستور ونص المسادة (0/ /ب) من قانون المحكمة الاستورية قد حملا في طياتهما من جسامة العيب الثيء الكثير ، وهما نصان منتقان لما فيهما من مجافاة لمبادئ ثابتة في الفقه الاستوري والقانوني، وذلك بالنظر فئر

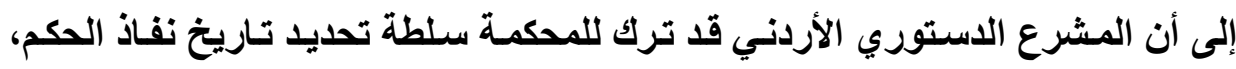
وجعل هذا الأمر من قبيل السلطة التقديرية للمحكمة، إذ أن مسألة النفاذ من ابرز الأمور وأهمها فيما يتعلق بالحكم القضائي، فلا نتصور أن يترك أمر تحديدها لوقت سـابق أو الو لاحق، باستثناء ما استقر عليه الفقه الاستوري، والقانوني في الموضوعات الجزائية

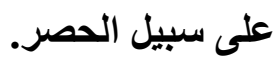

ومن ناحية أخرى يمكن أن نتصور أن يتضمن حكم المحكمة الاستورية الإثـارة

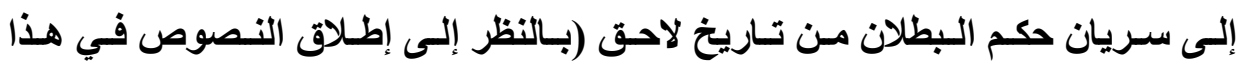

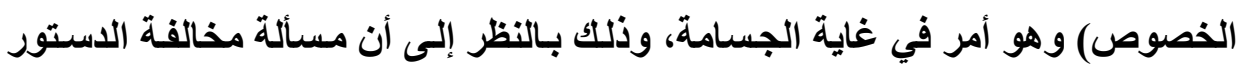

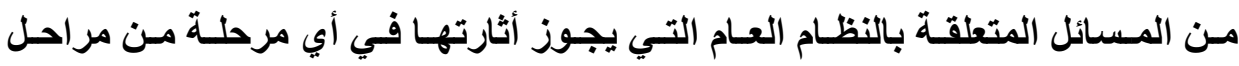

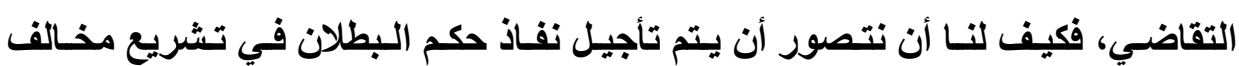
للاستور لموعد لاحق، مع تيقن المحكمة من عدم دستورية هذا النص، وهل هناك فائدة

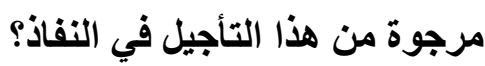

ويمعنى آخر هل يجوز هنـا للقاضسي أن يقوم بتطبيق نص قـانوني قد صدر

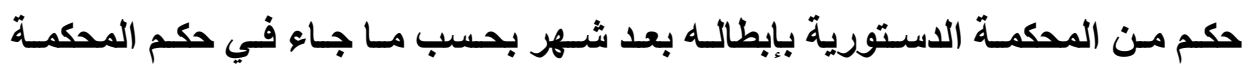

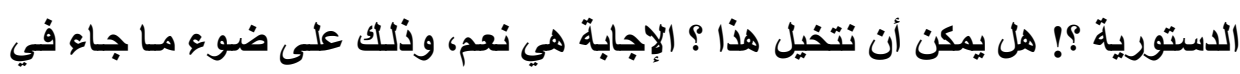


نص المسادة (1/09) مـن الاستور والمـادة (ه //ب) مـن قـانون المحكمـة الاستورية

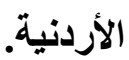

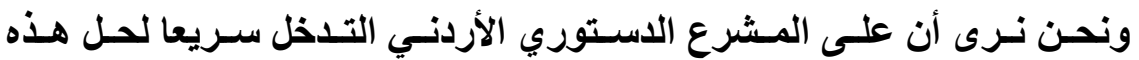

المشكلة، وتعديل نص المـادة (1/09) وتصويب هذا الخطأ الجسيم، بالإضـافة لتعديل نص المـادة (ه /ب) من قانون المحكمة الدستورية، وذلك بأن يقوم المشرع بإلغاء صلاحية المحكمة في تحديد وقت النفاذ، ويترك الأمر فيمـا يتعلق بالرجعية في النفاذ

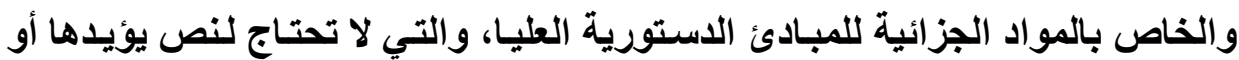
يثبت وجودها، (') و التي تثثير إلى أن بطلان القانون أو النظام يسري بأثر رجعي دون حاجة لإثبات ذلك في نص القانون، ولما كان ما تقدم وجب على المشرع الأردني تعديل هذا النص على وجه السرعة، وبالصورة التي اشرنا إليها أعلاه.

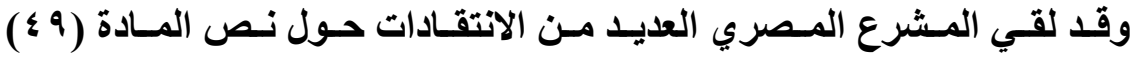
مـن قـانون المحكمة الدستورية العليـا فيمـا يتعلق بـأثر الحكم الصادر عن المحكمـة

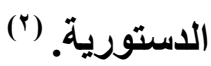
وقد تطرق جاتب من الفقه للحديث عن هذا الأثر الرجعي الذي يخلفه صدور الحكم بعدم الدستورية، وقد بينوا الاستثناءات التي تجري على هذا الأثر. (')

(1) ومن الأمثلة على هذه المبادئ عدم رجعية القانون وتطبيقه بأثر فوري مـا لم يكن أصلح للمتهم،

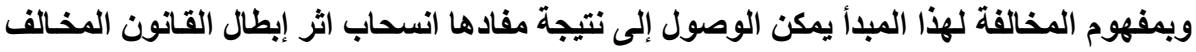
للاستور إلى الماضي في حال كان أصلح للمتهر.

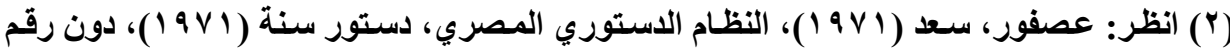

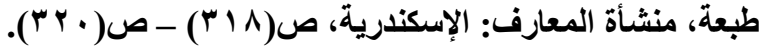


كما أن المشرع المصري جعل مسألة النفاذ تبدأ من اليوم التالي للنشر مـا لم يحدد الحكم تاريخا آخر، وبالتالي يرى الباحثان أن المشرع المصري قد وقع في ذات

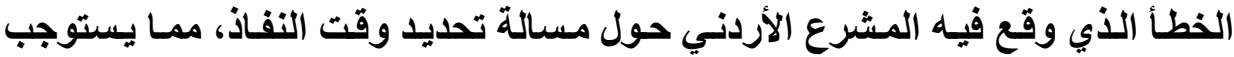
توجيه ذات النق للمشرع المصري في هذا الخصوص.(() إلا أن المشرع المصري قد وضع على ذلك استثناء في النصوص الضريبية، حيث يكون الأثر مباشرا دائمسا وأبدا دون الإخلال باستفادة المدعي من الحكم الصادر

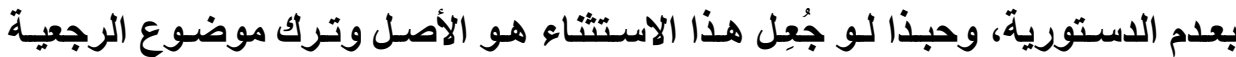
للمبادئ الاستورية العليا والتي تضمنها الدستور. (") كمـا إنتـا نـرى عدم الحاجـة للفقرة (د) مـن المسادة (ه 1 ) مـن قـانون المحكمـة الدستورية بالنظر لما كنا قد بينـاه حول موضوع النفاذ أعلاه، كمـا أن أمر التباين في وقت نفاذ الحكم بين نص وآخر (جميعهم مخالفين للاستور) يؤدي إلى إثارة الثكك حول معيار المساواة بين الأفراد، و يثكل بحد ذاته مخالفة دستورية كما نرى. كما أن مسألة إبقاء سلطة تحديد وقت النفاذ بيد المحكمة قد يتضمن إهدار لمبدأ حمايـة الحقوق المكتسبة في بعض الأحيان، وهو أمر في غاية الأهمية ويجب على لهان المشرع الأردني أن يعمل على حمايته بشكل اكبر من ذلك، وان لا يترك لحكم المحكمة أي سلطة للمساس بهذه الحقوق المكتسبة.

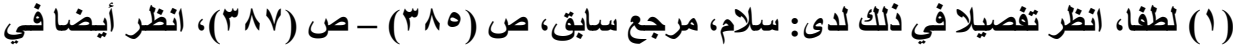

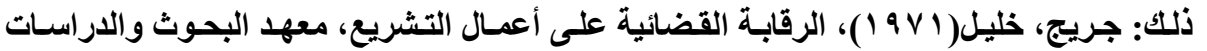

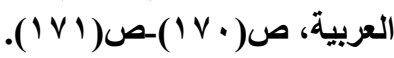

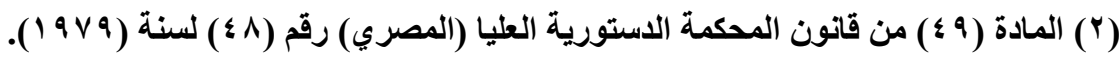

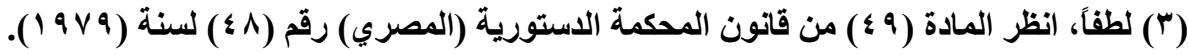




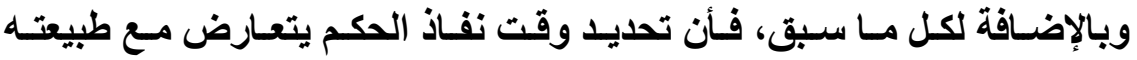

الكاثشفة، إذ أن الحكم هنـا غير منشئ وإنمـا كاثـف، يكشف عن التشريع المخـالف للاستور ويعلن بطلانه على الملأ. أما فيما يتعلق بقرارات التفسير فلا تكون نافذة إلا بعد نشر القرار في الجريدة الرسمية، ويكون حجة على الكافة منـذ ذلك التـاريخ، ويصبح بالتـالي مكمـلا للنص النص

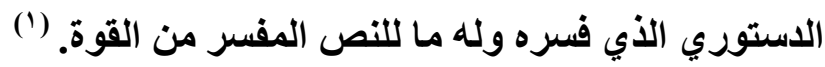

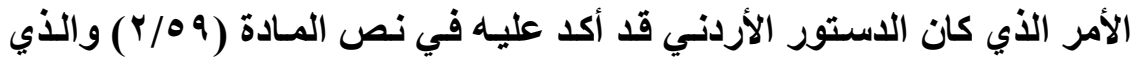
جاء فيها: "للمحكمة الدستورية حق تفسير نصوص الاستور إذا طلب إليها ذلك بقرار" صادر عن مجلس الوزراء، أو بقرار يتخذه أحد مجلسي الأمة بالأظلبة، ويكون قرارها نافذ المفعول بعد نثره في الجريدة الرسمية". كما وقد جاء في نص المادة (V V ) من قانون المحكمة الدستورية ما يلي: "للمحكمة حق تفسير نصوص الاستور إذا طلب إليها ذلك بقرار صـادر عن

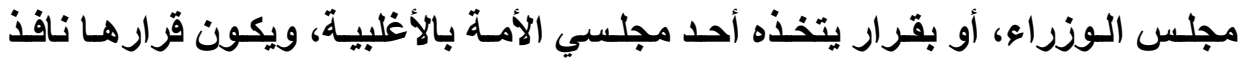
المفعول بعد نثره في الجريدة الرسمية".

(1) ولا يمكن اعتبار القرار التفسيري الصادر عن المحكمة الدستورية بمثابة تعديل للنص الاستوري

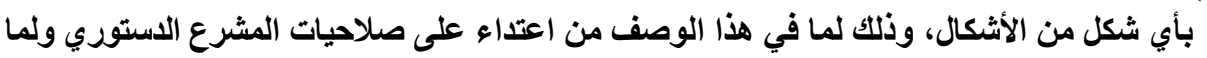

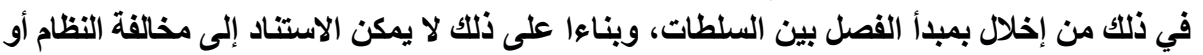
القانون لهذا التفسير لغايات اعتباره محلا للطعن بعدم الاستورية. 
أمـا قرارات التفسير الصادرة عن المحكمة الاستورية العليـا فلها مـن القوة

والنفاذ ما للأحكام الصادرة في الطعون من قوة. (')

الفرع الثاني: حجية أحكام المكمة الدستورية: وفيمـا يتعلق بحجية أحكام

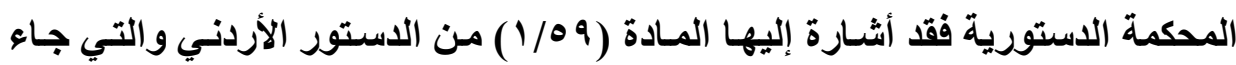

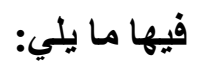

"... وتصدر أحكامهـا باسـم الملثك، وتكون أحكامهـا نهائيسة وملزمسة لجميع

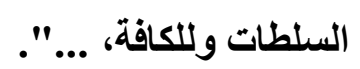

أما المشرع المصري فقد أثشار في قانون المحكمة الدستورية العليا في المسادة

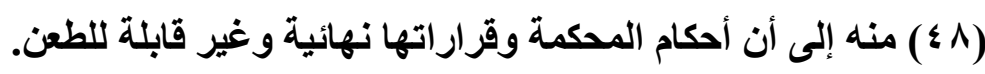

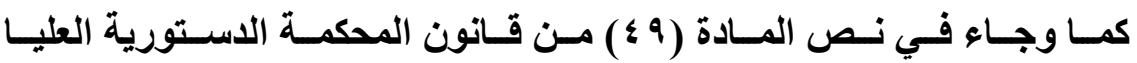

\section{مايلي:}

"أحكام المحكمة في اللاعاوى الاستورية وقراراتها بالتفسير ملزمسة لجميع

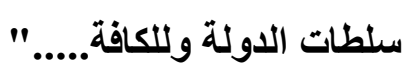

وبناءا على ذلك نجد أن المشرع الاستوري قد جعل لأحكام المحكمة الدستورية المتعلقة بطعون عدم الاستورية حجية على جميع السلطات داخل الدولة، وعلى الكافة، كما أن أحكام المحكمة غير قابلة للطعن بأي طريق من الطرق العادية، أو غير العادية، وهو ما يصدق عليه القول بالنسبة للمحكمة الاستورية العليا.

(1) المادة (9 §) من قانون المحكمة الدستورية العليا (المصري) رقم (^ ؛ ) لسنة (9 \ ( ). 
كمـا أن المسادة (ه //أ) من قـانون المحكمة الدستورية أكدت على مـا جاء في الدستور الأردني، إذ أثارة في عجزها إلى أن الأحكام الصادرة عن المحكمة الدستورية أحكام نهائية وملزمة لجميع السلطات والكافة.

أضـف إلـى ذلــك أن هـذا الحكم يسري فـي مواجهـة جميـع سـلطات الدولــة ومؤسساتها، ولا يجوز لهذه السلطات مخالفة ذلك الحكم و إلا اعتبر ذلك مخالفة مباشرة للاستور في حال كان الحكم يقضي ببطلان قانون، أو نظام معين، وعملت احد هذه السلطات على تطبيقه مع علمها بحكم المحكمة الذي صدر بإبطاله. كما أن أحكام المحكمة الاستورية الأردنية، والمحكمة الاستورية العليا المصرية ملزمسان للكافـة، بحيث يشمل جميـع أفراد الشعب ومؤسسساته الحكوميـة، والأهليـة، والهيئات المعنوية القائمة فيه.

أما الأثر الذي يترتب على نفاذ حكم المحكمة الدستورية فيتمثل ببطلان القانون، أو النظام المخالف للاستور في حالة الطعن بعد اللستورية، أو إعلان سلامة التشريع الطعين من شبهة عدم الاستورية. في حين أثشار المشرع المصري في قانون المحكمة السستورية إلى أنه يترتب على الحكم بعدم دستورية نص في قانون أو لايحة عدم جواز تطبيقه من اليوم التالي لنشر الحكم. (1) 
أما في حالات قرار التفسير، فيترتب على ذلك كثف الغموض الذي كان يكتنف النص الدستوري، بالإضـافة إلى أن هذا التفسير قد أصبح جزءا من النص المفسر،

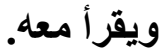

أما اثر التفسير للاى المشرع المصري فينصرف إلى السبب الذي تم التفسير

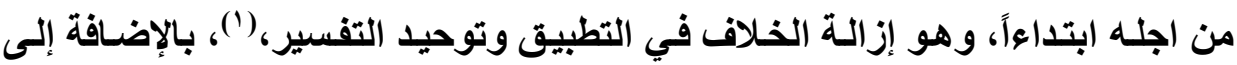

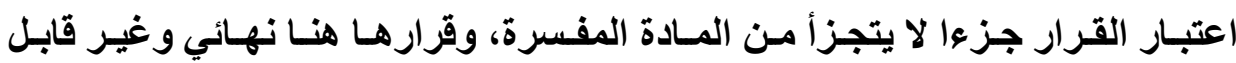

(†). للطعن

ونشير هنا إلى أمر في غايـة الأهمية، ألاوهو حالة قيام المحكمة الدستورية

بعدم قبول الدعوى شكلا لأي سبب من الأسباب قبل الدخول بالموضوع، فأن هذا لا لا يمنع من إمكانية إعادة تقديم دفع آخر في ذات الدعوى من قبل ذات الطاعن، أو في لإي دعاوى أخرى من ذات الطاعن أو من غيره، وسندنا في ذلك أن القانون لم يقيد في عدد مرات الطعن، بالإضافة إلى أن هذا الدفع هو دفع موضوعي يمكن إثارته في أي مرحلة من مراحل الاعوى ما لم يتطق الأمر بموضوع الجدية. ونؤكد أيضا على أمر آخر حول النصوص التي قضت المحكمة بسلامتها من

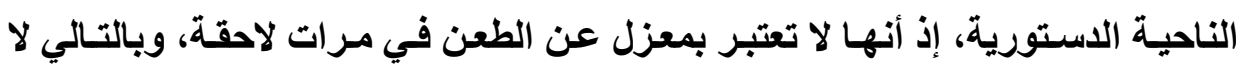
يكتسب حصانة قضائية كما قد يعتق البعض، إذ أن المحكمة عندما قضت بسلامة النص

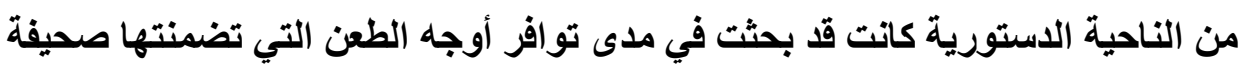
ذلك الطعن فقط، وبالتالي فق يكون الطاعن قد غفل عن احد الأسباب والذي من المكن فئن

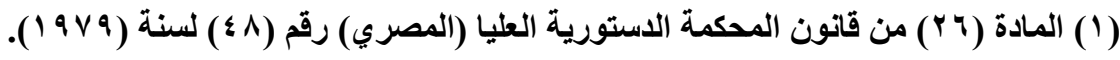

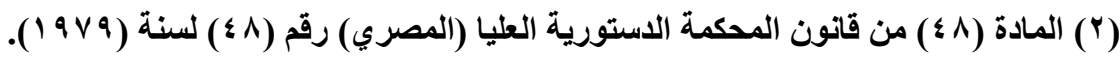

مجلة البحوث القانونيت والإقتصاديت . 
أن ينـال من سلامة التشريع من الناحية الدستورية، وبالتـالي فلا شـيء يمنع من أن

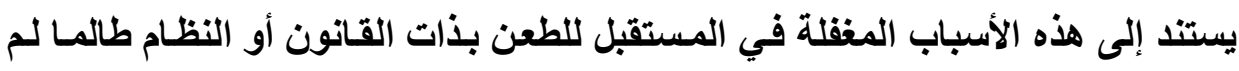
تبحثها المحكمة في أحكامها السابقة، إذ أن القاضي لا يحكم بأكثر من مـا جاء في طلب لابل

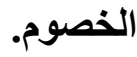

ونؤكلد أيضا ضرورة أن لا يتقيد القاضسي بحدود صحيفة الطعن في اللدعوى اللستورية على وجـه الخصوص، وذلكك بـالنظر إلى أن القاضـي الاستوري وظيفته

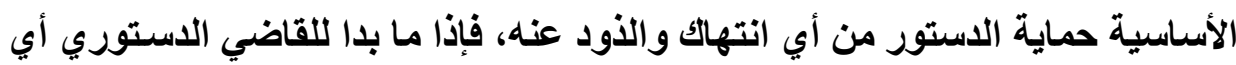

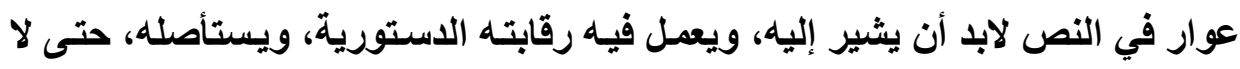

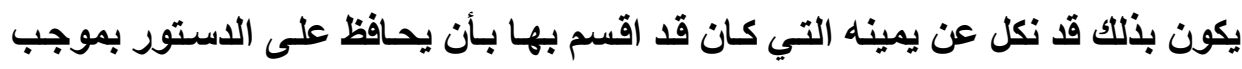

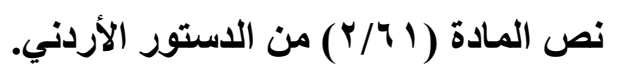
ونشير أخيرا إلى الأثر الذي يترتب على الحكم بعدم دستورية تشريع معين،

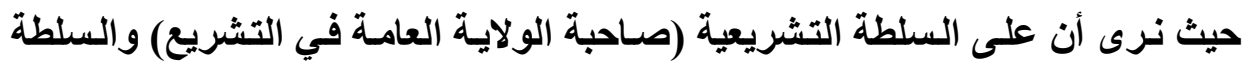

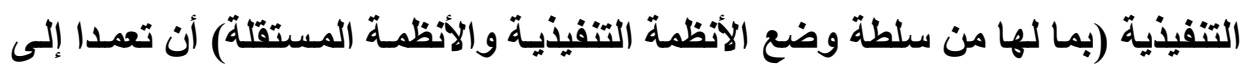
تعديل كافة النصوص التي قضي بعدم دستوريتها، أو استئصالها من التشريعات التي وضعتها، وذلك بعد أن تدرس حكم المحكمة بشكل دقيق، لتتلافى الوقوع في ذات العيب

$$
\text { مستقبلا. }
$$

ويرى جانب من الفقه أن مهمة الرقابة التي يقوم بها القضاء الاستوري تكمن

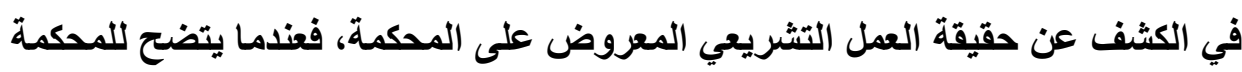
أن التشريع مخالف للاستور فنلك يعني انه لم يعد تثريعا بالمعنى الفني لهذا الاصطلاح بالنظر إلى مخالفته الثروط التي رسمها الدستور من حيث الثكل أو الموضوع، وبناءا 
على ذلك فأن الحكم الصادر عن المحكمة يؤدي إلى إضفاء صفة الانعدام على التشريع المخالف للاستور ليس من لحظة صدور الحكم، وإنمـا ينصرف هذا الأثر إلى لحظة صدور التشريع ذاته، (') وهو ما لا نتفق معله، إذ أن هذا التشريع قد يكون رتب العديد من الحقوق المكتسبة في ظله ممـا يتعارض مـع فكرة التوازن داخل المجتمع فيمـا لو قمنا بهام كافة العلاقات القانونية التي تمت في ظله، أضف إلى ذلك أن مسألة الرجعية هي الاستثناء، ولا يمكن اللجوء لها إلا في الموضوعات الجزائية فقط، فالمشرع في كثير من الأحيان يرجح كفة التوازن على كفة العدالة.

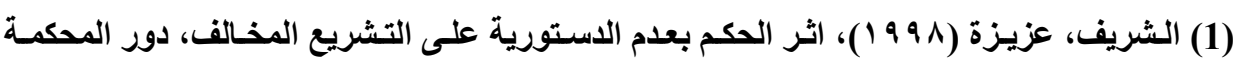

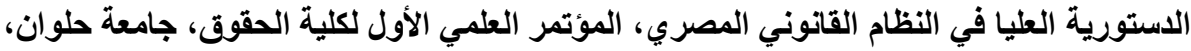

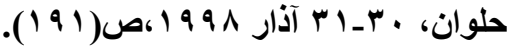




\section{الخاتهة}

لقد شكلت المحكمة الاستورية الأردنية ابرز مخرجات الإصلاح الشامل الذي كان قد دعا اليه جلالة الملك عبد الله بن الحسين- حفظه الله - وعملت بوجودهـا هذا على تحقيق التـوازن التشريعي، وضبط كل مخالفة للاستور، وقد انتقل المشرع الدستوري الأردني بذلك من اللامركزيـة في الرقابة على دستورية القوانين والأنظمة

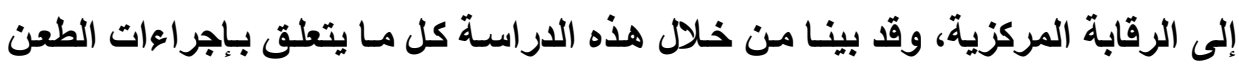

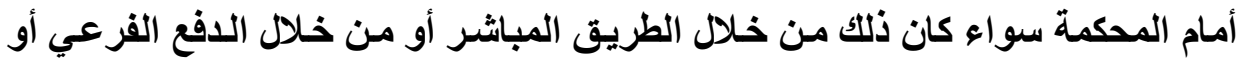
من خلال (الدعوى المباشرة) بطريق غير مباشر بناءا على الضغوط الثعبية، وقد بينا

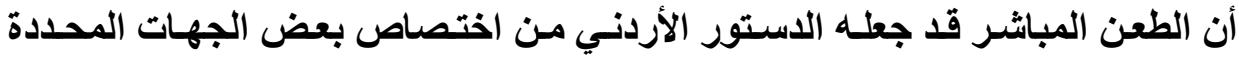
حصر أ والمتمثلة بمجلس الوزراء، ومجلس النواب، ومجلس الأعيان فقط، وبينا ماهية هذا الطعن والذي يعتبر بمثابـة الوسيلة الهجوميـة للدفاع عن الاستور مـن جراء

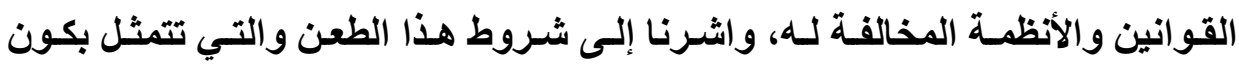
القانون أو النظام ناففا، وان لا يكون قد سبق وحكم ببطلانـه أو تم تأكيد دستوريته في ذات نقطة الطعن، وان لا يكون النص الطعين متطقا تعلق وجودي مع نص آخر حكم ببطلانه، والثرط الأخير يتمثل بصدور قرار من احد الهيئات التي حددها الدستور حصرا لممارسة هذا النوع من أنواع الطعن، ومـا يتلو ذلك من إجراءوات عملية أمسام

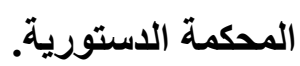
كمسا أثـارت الاراسـة إلى الطريـق الثـاني الذي يمكن من خلالـه الطعن بعدام دستورية القو انين أو الأنظمة المخالفة للاستور و المتمثل بالدفع الفرعي في الداعوى لـاني 
المنظورة أمسام المحساكم على اختلاف درجاتها و أنواعها، حيث يشترط لسلوك هذا الطريقى أن يكون هــاك دعوى منظورة أمسام القضاء، وان يقدم الـفع مـن صـاحب المصلحة للمحكمة النـاظرة للاعوى، بالإضافة لضرورة تقديم الطعن من خلال محام

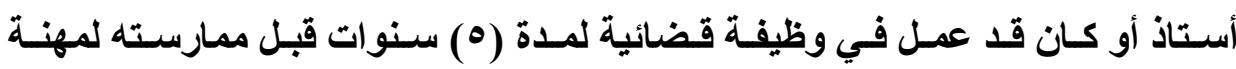
المحاماة، وان يقام الطاعن طعنه بموجب وكالة خاصة تتضمن الطعن بعدم الاستوري، وان يكون القانون أو النظام واجب التطبيق، وان يكون هذا الدفع على قدر من الجدية، ليصار بعد اكتمال هذه الثروط العمل على إحالة هذا الدفع إلى محكمة التمييز والتي بدورها تحيلها إلى المحكمة الدستورية في حال وجدت أن الدفع جدي، وعندئذ تتولى لئى المحكمة الدستورية مهمتها في البت في هذا الدفع، وقد أظهرت الدراسـة الإجراءات

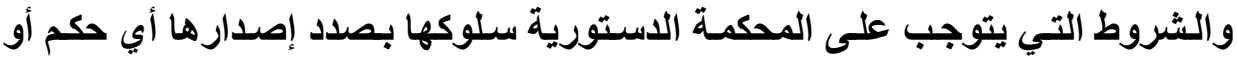
قرار، والتي تمثلت بشرط المدة، وشرط التسبيب، وشرط أن يكون الحكم أو القرار صادرا باسم جلالة الملك، بالإضافة إلى مراعاة التشكيل القضائي الذي تطلبه المشرع

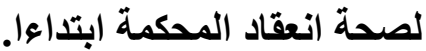
وبينت الاراسة أن الأحكام التي تصدر عن المحكمة الاستورية تكون نافذة بائر مباشر ما لم يحدد الحكم تاريخا آخر للنفاذ، كما أن الأحكام الصادرة عن المحكمة نهائية

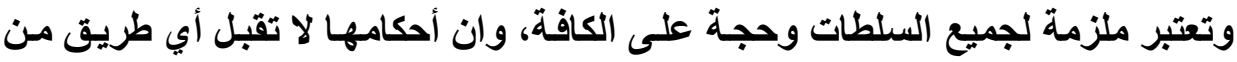
طرق الطعن العادية أو غير العادية. وبناءا على كل ما تقدم فقد توصل الباحثان إلى جملة من النتائج و التوصيات

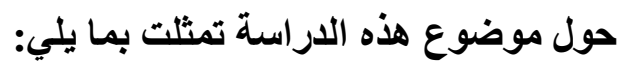




\section{أولاً: النتائج}

1- إن الصياغة التثريعية التي جاء بها المشرع عندما نص على اختصاص المحكمة

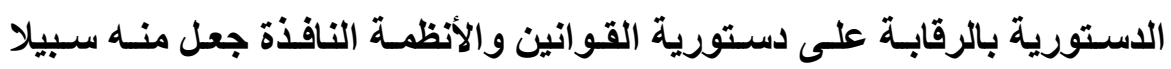

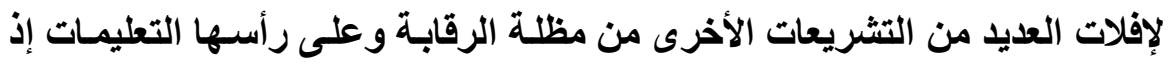

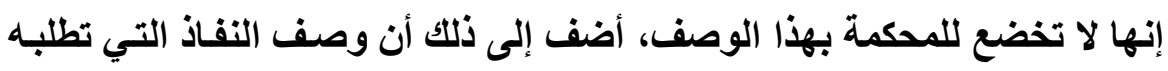
المشرع يؤدي إلى إفلات القو انين الموقوفة من هذه الرقابة. r- إن المشرع الأردني عندما اوجد المحكمة الاستورية الأردنية قد جعل السبيل إلى بـ بلوغها مـن أصـب الطرق، إذ عمـل على وضـع العديــ مـن العر اقيـل الإجرائيسة والموضوعية ، والمالية لمنع الوصول إلى المحكمة الدستورية. ץ- إن محل المخالفة الدستورية التي يمكن للطاعن أن يؤسس دعواه بالاستناد إليه

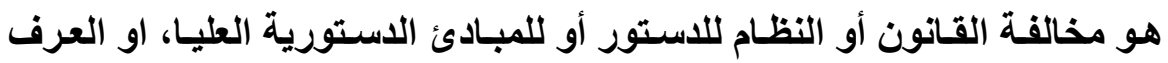

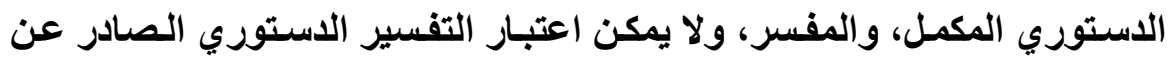

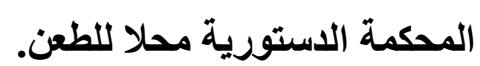
؛- إن الطعن بعدم الدستورية لا يكون إلا من خلال الاعتمـاد على عدة أوجه، والتي

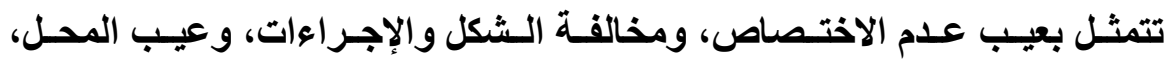
والانحر اف في استعمال السلطة. هـ تستلك الدعوى الدستورية إحدى طريقين فإما أن تكون من خلال الطريق المباشر،

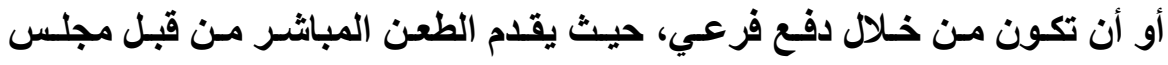
الوزراء أو مجلس النواب أو مجلس الأعيان، في حين أن الدفع الفرعي لا يكون إلا من خلال صاحب المصلحة في الدعوى الموضوعية. 
آ- يجب لغايات الدفع الفرعي أن يكون الدفع منطوياً على قدر من الجدية وهو الأمر

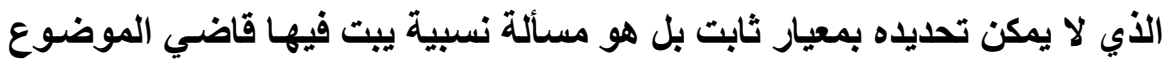

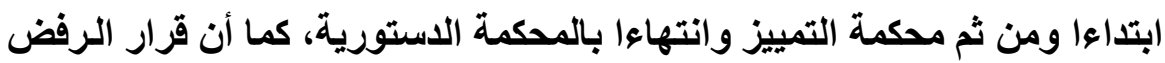
للإحالة يكون قابلا للطعن بالطرق التي يطعن فيها في موضوع الدعوى. V- - إن الأحكام والقرارات التي تصدر عن المحكمة يجب أن تكون مسببة وصـادرة باسم جلالة الملك، ووفق التشكيل القضائي الذي تطلبه المشرع لذلكل، وتكون الأحكام طالما تم استيفاء هذه الثروط حجة على الكافة وملزمـة لجميع السلطات في الدولة، وبخلاف ذلك يكون قرار المحكة باطلاً.

\section{ثنانياً: التوصيات.}

وفي نهايـة هذه الاراسـة لا يسعنا إلا أن نقدم جملة من التوصيات وهي على النحو

1. يوصي الباحثان بأن يعمل المشرع الاستوري الأردني بتعديل نص المسادة (1/09)

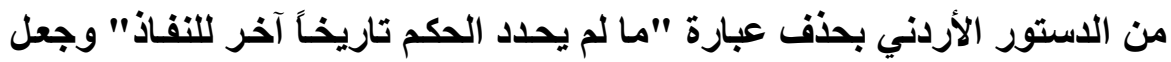

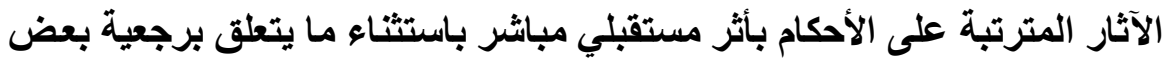
الأحكام في الموضوعات الجزائية، وذلك بالنظر إلى ما بيناه في ثنايا هذه الاراسة. ץ. يوصي الباحثان بأن يعمل المشرع الدستوري الأردني على منح كافة المحسكم

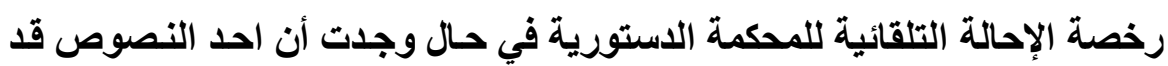
اعتراه شبه دستورية أسوة بالمشرع المصري.

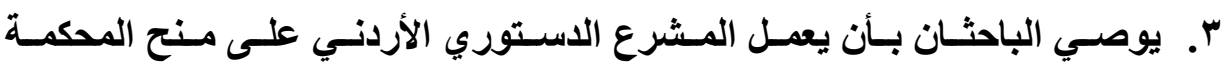
الدستورية رخصة التصدي والإحالة من تلقاء نفسها والبحث في أي نص تجد انـه 
مخالف للاستور، دون التقيد بالجهات الثلاث التي حددها الدستور لممارسة هذه الاختصاص اللصيق بشخصية المحكمة، وذلك أسوة بالمشرع المصري. ؛. يوصي الباحثان بأن يعمل المشرع الاستوري الأردني وكذلك المشرع القانوني على إزالة كافة العراقيل والصعوبات التي تم وضعها في طريق الطاعن في الدفع القرعي، وعلى رأسها ما يتعلق بموضوع الجدية وما فيه من إجراءات، وتكرار لا طائل منه سوى بث الوهن في نفس الطاعن، هذا فضلا عن باقي العراقيل المتمثلة بالأعباء المالية الكبيرة التي يدفعها الطاعن في كل دور من ادوار فحص الجدية. •. يوصي الباحثّان بأن يعمل المشرع الدستوري الأردني على تعديل نص المسادة

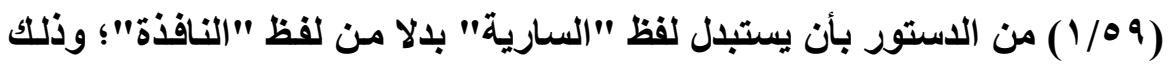
بالنظر إلى وجود قوانين سارية على موضوع الدعوى ولكنها غير نافذة، اذ يرى الباحثنان أن لفظ سـارية أكثر شـولية مسن وصف نافذة، بالإضـافة إلى شـوله القو انين موقوفة النفاذ بمظلة الرقابة. T. يوصي الباحثان بضرورة قيام المشرع الأردني بالنص على ما يتعلق بضرورة ان

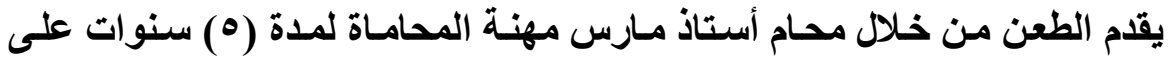

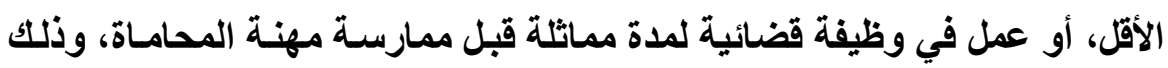
بنص صريح بدلا من ترك الأمر محلا للجدل حول هذه الصفة والذي اشرنا إليه عند الحديث عن نص المـادة (ץ //أ/ץ) من قانون المحكمة الاستورية الأردنية، بالإضافة إلى ضرورة الإثـارة إلى شرطوجود وكالة خاصة لغايات أمر الطعن بالدفع الفرعي، بلالا من ترك الأمر للاجتهادات القضائية والفقهية المختلفة. 
V. . يوصي الباحثان بضرورة إنشاء لجنة مختصة تابعة للمحكمة الاستورية يتم من خلالها فحص مدى الجديـة بالاستناد إلى وجود نص قانوني يبين ماهيـة الجديـة على نحو دقيق، على أن يـتم إحالـة الدعوى إلى هذه اللجنـة خـلال مـدة محددة

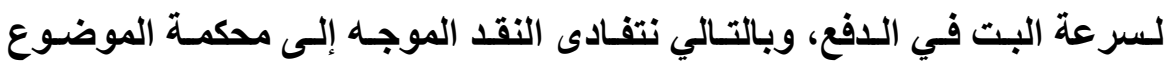
بوصفها تتـازع المحكمة الدستورية في اختصاصها، وبذلك نتلافى مشكلة عدم التحديد لمفهوم الجدية من الناحية التشريعية، ونجعل مسألة تحديدها يصدر من رحم المحكمـة نفسها بـلا مسن أن يترك الأمسر لاجتهـادات القضاة وتقــيراتهم المتباينة لمعنى الجدية 


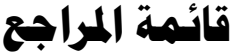

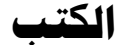

1. الباز، سيد (9Av (1)، الرقابة على دستورية القوانين في مصر، دراسـة مقارنة، الطبعة الأولى، دون مكان نشر: دار الجامعات المصرية.

ז'. بدوي، ثروت (£ ج9 1)، النظام الدستوري العربي، دون رقم طبعة، دون مكان

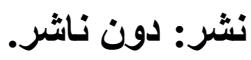

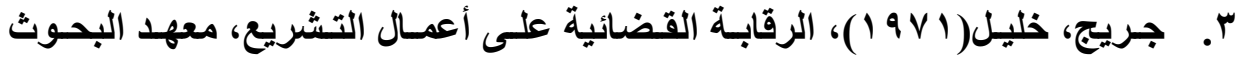

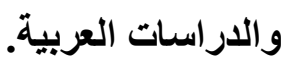

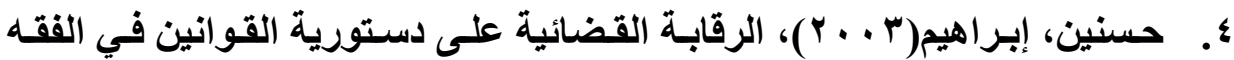
و القضاء، دون رقم طبعة، مصر: دار الكتب القانونية.

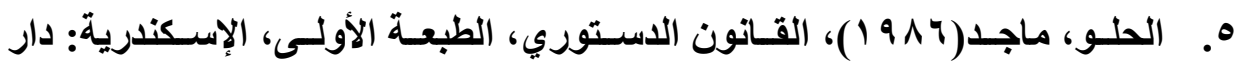

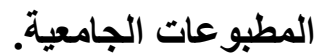

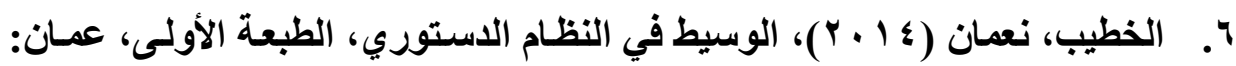

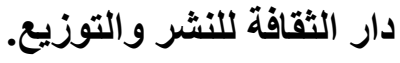

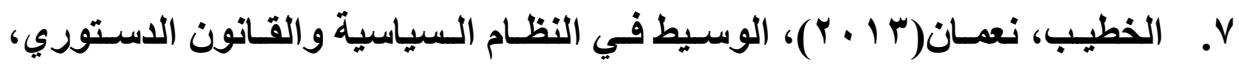
الطبعة التاسعة، عمان: دار الثقافة للنشر والتوزيع. 


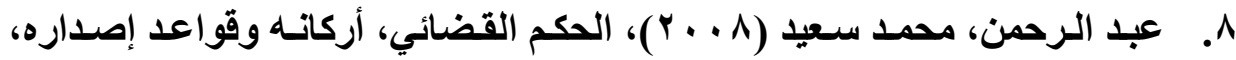
الطبعة الأولى، الإسكندرية، دار الفكر الجامعي.

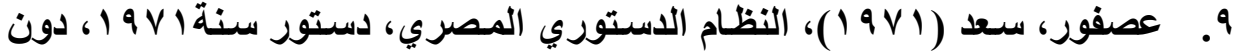
رقم طبعة، الإسكندرية: منشأة المعارف. • 1. العواملة، منصور(9 991)، الوسيط في النظم السياسية، المجلد الثاني، الكتاب

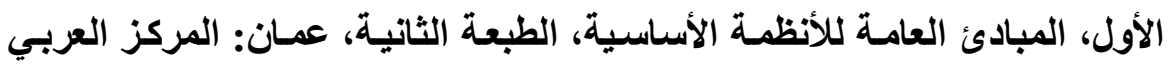

$$
\text { للخدمات الطلابية. }
$$

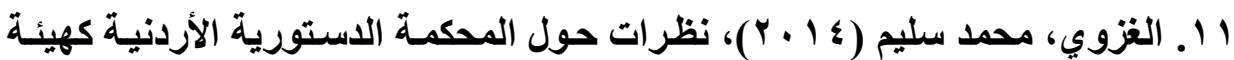
قضائية مستقلة للرقابة على دستورية القوانين والأنظمة، دراسة مقارنة، الطبعة

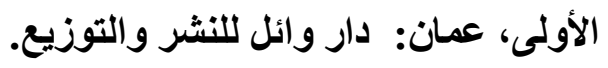
r ا . فوزي، صلاح الدين (ب 9 9 1)، الدعوى الاستورية، دون رقم طبعة، دون مكان

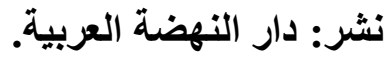

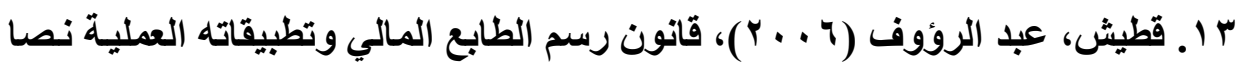
واجتهادا، الطبعة الأولى، بيزوت: منشورات الحلبي الحقوقية. ؛ ا ـ محفوظ، عبد المنعم (؟ 99 1)، القضاء الدستوري في مصر، الطبعة الأولى،

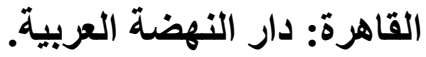
المؤتهرات والندوات 1. أبو عامود، محمد(991 (1)، المحكمة الدستورية والنظام السياسي المصري، دور المحكمة الدستورية العليـا في النظام القـانوني المصري، المؤتمر العلمي الأول 


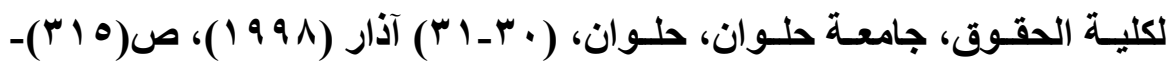

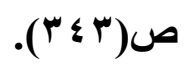

r. سـالمان، عبد العزيز (9 991)، نظم الرقابـة علـى دستورية القوانين، دراسـة

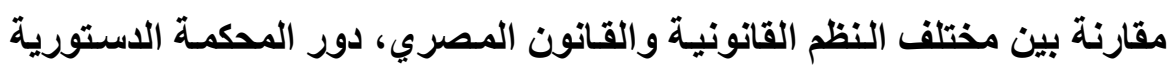

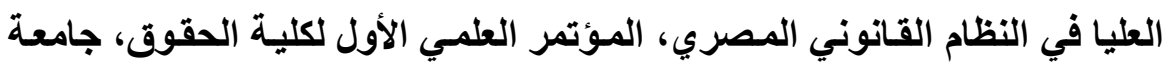

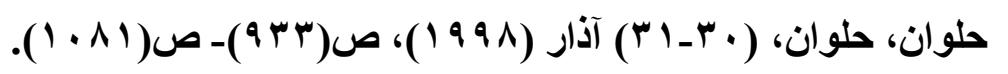
r. سلام، رفيق محمد (991) (191)، الآثار القانونية لأحكام المحكمة الاستورية العليا، دور المحكمة الدستورية العليا في النظام القانوني المصري، المؤتمر العلمي الأول

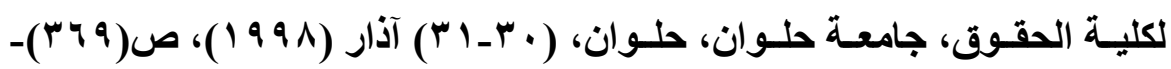

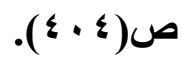
؛. الشريف، عزيزة (991 (1))، اثُر الحكم بعدم الاستورية على التشريع المخالف، دور المحكمة الدستورية العليا في النظام القانوني المصري، المؤتمر العلمي الأول

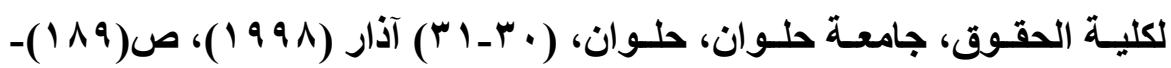

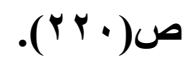

๑. الطبطبائي، عادل (9191)، مفهوم الطعن المباشر في النظام الاستوري الكويتي،

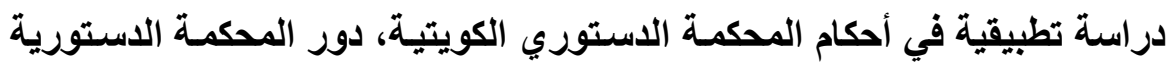

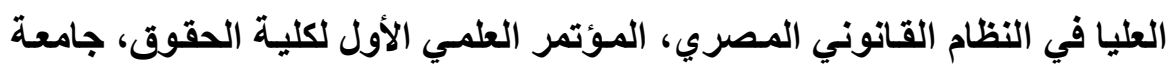

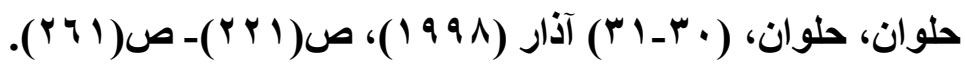




\section{رسائل علمية غير هنشورة}

ا. العيلي، عبد الحكيم (دون سـنة نشر)، الحريـات العامـة، رسـالة دكتوراه (غير

منشورة)، دون اسم جامعة، دون مدينة، دون دولة.

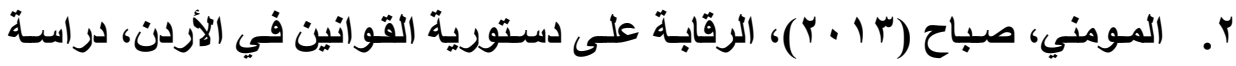
مقارنـة تحليلية في ضوء التعديلات الاستورية لسنة (1) ب ب)، رسـالة دكتوراه (غير منشورة)، جامعة العلوم الإسلامية العالمية، عمان، الأردن.

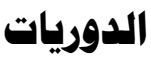

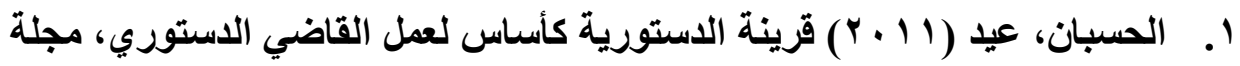

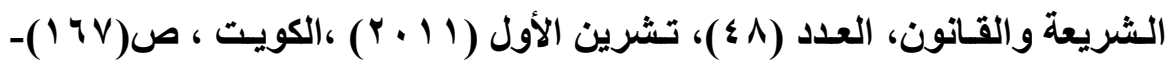

\section{التشريعات}

ا ـ تعليمات إجراءات الفصل في الطعون وطلبات التفسير الصادرة عن الهيئة العامـة للمحكمة الدستورية لعـام (ع ا ب ץ)، والصادرة في الجريدة الرسمية في العداد

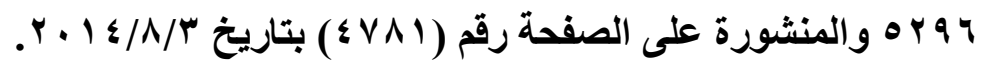

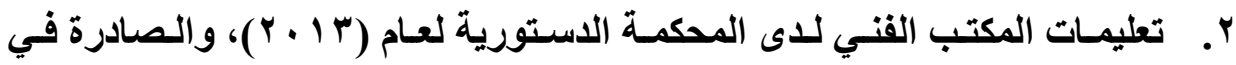

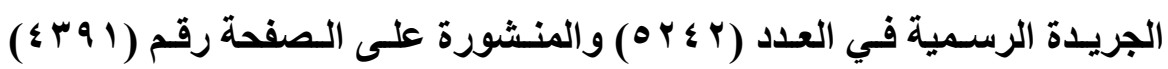

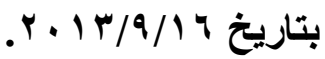
r. الاستور الأردني لسنة (roه 19) وتعديلاته، والصادرة في الجريدة الرسمية في

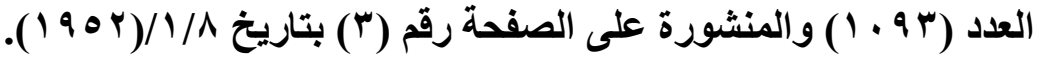




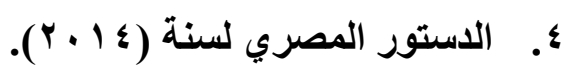

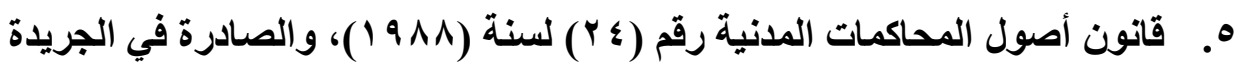

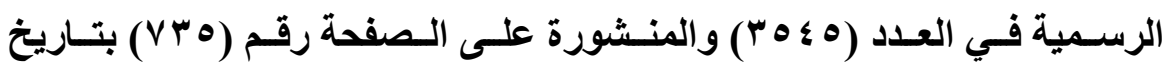
$.19 \Lambda \Lambda / \varepsilon / \%$

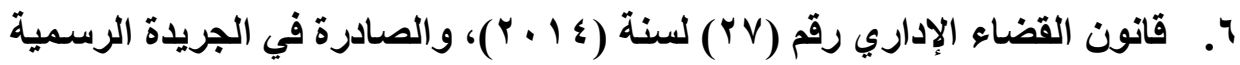

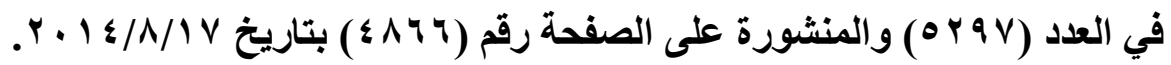

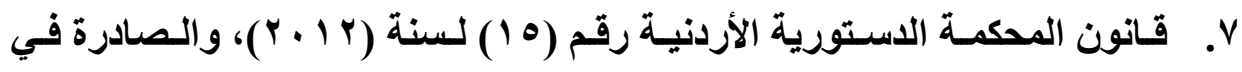
الجريدة الرسمية في العدد (17) 17 ) والمنشورة على الصفحة رقم (119)

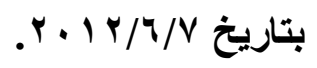

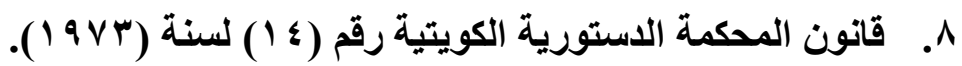

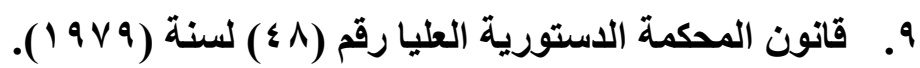

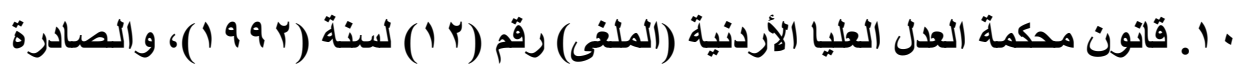

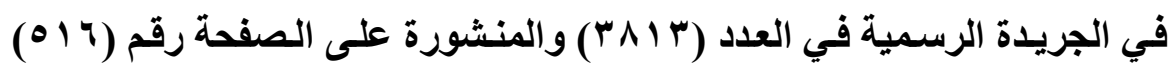

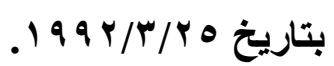

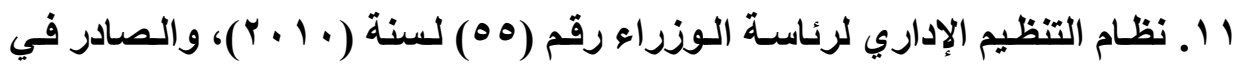

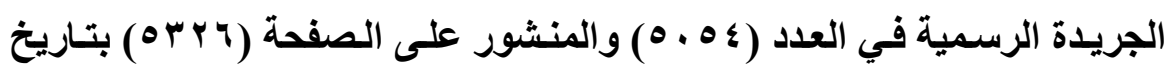

$$
r \cdot 1 \cdot / 9 / 1
$$

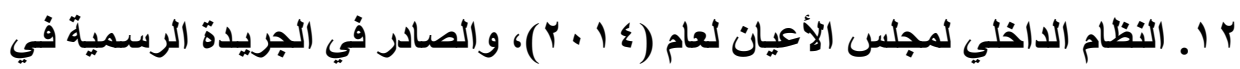

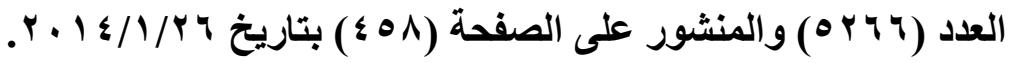




$$
\begin{aligned}
& \text { أ. أد/ فرحان نزال والمحامى/ بدرمحمد هلال } \\
& \text { العدد ال7 (ديسمبر r.17) }
\end{aligned}
$$

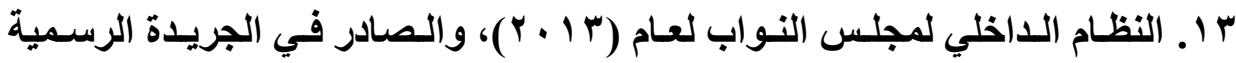

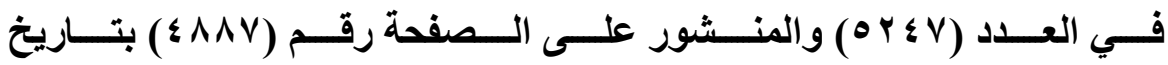

$$
\begin{aligned}
& . r+1 r / 1 \cdot / r \cdot
\end{aligned}
$$

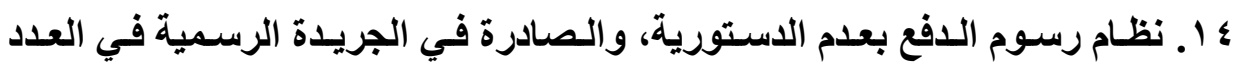

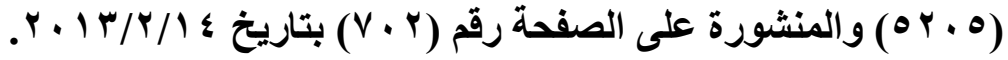

$$
\begin{aligned}
& \text { قرارات وأمكام } \\
& \text { ا ـ أحكام المحكمة الاستورية (الأردنية). } \\
& \text { r أحكام المحكمة الاستورية العليا (المصرية). } \\
& \text { r. أحكام محكمة التمييز الموقرة (الأردنية). } \\
& \text { ؛. أحكام محكمة العدل العليا (الأردنية). }
\end{aligned}
$$

